ISABELLA KATZ MIGLIORI

\title{
USO DE RNA DE INTERFERÊNCIA (siRNA) PARA MODULAÇÃO \\ DA EXPRESSÃO DAS MOLÉCULAS CO-ESTIMULADORAS \\ CD80 E CD86 EM CÉLULAS DENDRÍTICAS
}

Dissertação apresentada ao Programa de Pós-Graduação em Imunologia do Instituto de Ciências Biomédicas da Universidade de São Paulo, para obtenção do Título de Mestre em Ciências. 
ISABELLA KATZ MIGLIORI

\section{USO DE RNA DE INTERFERÊNCIA (siRNA) PARA MODULAÇÃO \\ DA EXPRESSÃO DAS MOLÉCULAS CO-ESTIMULADORAS \\ CD80 E CD86 EM CÉLULAS DENDRÍTICAS}

Dissertação apresentada ao Programa de Pós-Graduação em Imunologia do Instituto de Ciências Biomédicas da Universidade de São Paulo, para obtenção do Título de Mestre em Ciências.

Área de concentração: Imunologia

Orientador: Prof. Dr. José Alexandre M. Barbuto 
DADOS DE CATALOGAÇÃO NA PUBLICAÇÃO (CIP)

Serviço de Biblioteca e Informação Biomédica do

Instituto de Ciências Biomédicas da Universidade de São Paulo

(C) reprodução total

Migliori, Isabella Katz.

Uso de RNA de interferência (siRNA) para modulação da expressão das moléculas co-estimuladoras CD80 e CD86 em células dendríticas / Isabella Katz Migliori. -- São Paulo, 2010.

Orientador: José Alexandre Marzagão Barbuto.

Dissertação (Mestrado) - Universidade de São Paulo. Instituto de Ciências Biomédicas. Departamento de Imunologia. Área de concentração: Imunologia. Linha de pesquisa: Biologia da célula dendrítica.

Versão do título para o inglês: Use of small interfering RNA (siRNA) for modulating the expression of costimulatory molecules CD80 and CD86 on dendritic cells.

Descritores: 1. Células dendríticas 2. Moléculas co-estimuladoras 3. CD80 4. CD86 5.RNA de interferência 6. Imuno-modulação I. Barbuto, José Alexandre Marzagão II. Universidade de São Paulo. Instituto de Ciências Biomédicas. Programa de Pós Graduação em Imunologia III. Título. 
Candidato(a):

Título da Dissertação:

Orientador(a):
Isabella Katz Migliori.

Uso de RNA de interferência (siRNA) para modulação da expressão das moléculas co-estimuladoras CD80 e CD86 em células dendríticas.

A Comissão Julgadora dos trabalhos de Defesa da Dissertação de Mestrado, em sessão pública realizada a I... ....
( ) Aprovado(a)
( ) Reprovado(a)

Examinador(a): Assinatura:

Nome:

Instituição:

Examinador(a): Assinatura:

Nome:

Instituição:

Presidente: Assinatura:

Nome:

Instituição: 
UNIVERSIDADE DE SÄO PAULO

Săo Paulo, 23 de abril de 2008.

\section{PARECER 834/CEP}

Prezado Sennora.

Atendendo sua solicitação, a Comissão de Ética em Pesquisas com Seres Humanos do $1 \mathrm{CB}$. em sua $83^{\circ}$ reuniäo realizada em 22.04 .08 , analisou o projeto de sua responsabilidade intifulado: "Avaliaçăo da funçăo das moléculas coestimuladoras CD80 E CD86 em celulas dendriticas na capacidade de ativaçāo de infocitos T".

Informo a V.Sa. que, após análise e discussäo, o referido projeto fol aprovado por este Comissūo.

Lembramos que cabe ao pesquisador elaborar e apresentar a este Comitê, relatónios anuais (parciais ou finai), de acordo com a resoluçăo 196/06 do Conseiho Nacionai da Saúde, item ix.2 lerra $c$.

o primeiro relatório deverá ser encaminhado à Secretaria deste CEP em 22 de abril de 2009.

Atenciosamente,

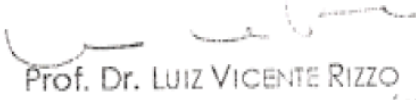

Coordenador da Comissāo de Ética em Pesquisas com Seres Hurnanos - ICB/USP

Ilma. Sra.

ISABELLA KATZ MIGLIORI

Departamento de Imunologia

Instituto de Ciências Biomédicas -USP

Comissāo de Ética em Pesquisa com Seres Humanos do instituto de Clências Biomédicas / USP Aprovada pela Comissāo Nacional de Ética em Pesquisa - CONEP. em 10 de fevereiro de 1998 
Decl. CEPSH. 100.2010

DECLARAÇ ÃO

Em adendo ao parecer PARECER 834/CEP-22.04.08, informo que o titulo do Projeto foi alterado para "Uso de RNA de interferência (siRNA) para modulação da expressão das moléculas co-estimuladoras CD80 e CD86 em células dendríticas" não apresentando restrições quanto às modificaçōes do projeto, que as mesmas não afetam os aspectos éticos da pesquisa.

São Paulo, 27 de outubro de 2010.

Prof. Dr. PAOLO M.A. ZanotTo

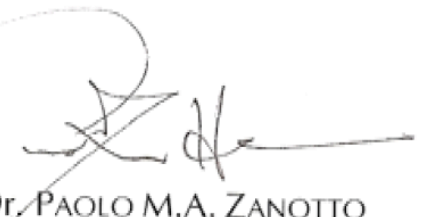

Coordenador da Comissão de Ética em

Pesquisas com Seres Humanos - ICB /USP

Comissão de Ética em Pesquisa com Seres Humanos do Instituto de Ciências Biomédicas - USP Aprovada pela Comissäo Nacional de Ética em Pesquisa - CONEP, em 10 de fevereiro de 1998. 
Ao Thiago, amor da minha vida. 


\section{AGRADECIMENTOS}

Ao meu querido orientador José Alexandre por seu exemplo, apoio, carinho, confiança e orientação segura no amadurecimento dos meus conhecimentos, que me levaram à execução e conclusão desta dissertação.

À Dra. Patrícia Bergami, pelo auxílio e carinho irrestritos.

Aos meus pais Marta e Luis, minha irmã Barbara, minha avó Ernestina e meu avô Paulo (in memorian), meus tios e primos, meu namorado Thiago e família, e a toda minha família, que com muito carinho e apoio, não mediram esforços para que eu chegasse até esta etapa de minha vida.

A todos os meus amigos do Laboratório, que contribuíram para minha formação como pesquisadora, e por terem feito do nosso grupo de trabalho uma família, tanto dentro quanto fora do Laboratório, em especial à Bruna, Graziela, Lilian e Patrícia. Sem vocês, não teria sido tão divertido.

Ao amigo Otávio, que nunca mediu esforços para auxiliar, sempre disponível, atencioso e alegre.

À Célia e, mais recentemente, à Claudinha, pelo carinho e pronto-auxílio, sempre.

Aos meus amigos mais queridos da faculdade, que me acolheram como irmã, Janayna, Priscilla e Flávio, por terem compartilhado as minhas conquistas, pelo incentivo e apoio constantes, pelas alegrias e dificuldades passadas juntos.

Às minhas eternas amigas de escola, que acompanharam minha jornada, Juliana, Marcella, Nathália, Renata L. e Renata P. Pelos momentos inesquecíveis passados juntas.

A todos os professores, que contribuíram para a minha formação, em especial ao Prof. Niels, pelo carinho e confiança depositada em mim, e à Profa. Maristela, pelas discussões construtivas.

Aos colegas do Departamento, que direta ou indiretamente me auxiliaram durante essa jornada. 
Aos funcionários do Departamento, Jotelma, Amanda, Eny, Amarildo (in memorian) e Thiago, por toda a ajuda prestada em questões burocráticas. Nada teria sido possível sem vocês.

À FAPESP, pela bolsa concedida.

Obrigada a todos! 
"A hard beginning makes a good ending."

(John Heywood) 


\section{RESUMO}

MIGLIORI, I. K. Uso de RNA de interferência (siRNA) para modulação da expressão das moléculas co-estimuladoras CD80 e CD86 em células dendríticas. 2010. $101 \mathrm{f}$. Dissertação (Mestrado em Imunologia) - Instituto de Ciências Biomédicas, Universidade de São Paulo, São Paulo, 2010.

As moléculas co-estimuladoras CD80 e CD86, expressas na superfície de células dendríticas (DCs), as principais células apresentadoras de antígenos profissionais (APCs), possuem participação fundamental na indução de resposta e manutenção de tolerância, motivo pelo qual são consideradas alvos terapêuticos promissores. Essas moléculas promovem o segundo sinal necessário à ativação e proliferação dos linfócitos $T$ por meio da ligação ao receptor CD28, ou inibem a resposta por essas células por meio da ligação ao receptor CTLA-4, ambos expressos na superfície dos linfócitos. Muitos são os relatos da literatura indicando diferenças tanto quantitativas quanto qualitativas entre CD80 e CD86 na capacidade de ativação de linfócitos $T$, os mais relevantes apontando diferenças na capacidade de indução de diferenciação de linfócitos para os padrões Th1 e Th2 de secreção de citocinas. Porém, tais relatos são muitas vezes contraditórios, e o verdadeiro papel funcional dessas moléculas ainda está por ser estabelecido. Assim, propusemo-nos a estabelecer as metodologias necessárias para silenciar as moléculas CD80 e CD86 em células dendríticas (DCs) humanas, derivadas de monócitos do sangue periférico, por meio da tecnologia de RNA de interferência. Isso possibilitaria esclarecer o papel desempenhado por cada uma dessas moléculas na capacidade de ativação de linfócitos T. Para tanto, padronizou-se a transfecção reversa de DCs do quarto dia da cultura com siRNA fluorescente e os agentes de transfecção lipídicos siPORT e iMAX, tendo sido obtidas eficiências de transfecção de $64,7 \% \pm$ 5,2 e $69,7 \% \pm 14,5 \%$, respectivamente. DCs do quarto dia de cultura foram transfectadas com siRNAs específicos para CD80, e o fenótipo avaliado após 48 horas da transfecção. Foi possível identificar, além do eficiente silenciamento de CD80 por dois dos três siRNAs testados, também uma diminuição, inesperada, de células $\mathrm{CD} 6^{+}$. Para o silenciamento de CD86, células $\mathrm{CD} 14^{+}$selecionadas positivamente por beads magnéticas foram transfectadas com siRNAs especíicos para CD86, ativadas após 24 horas da transfecção e o silenciamento avaliado após 24 horas da ativação. Embora o silenciamento conseguido por um dos dois siRNAs 
testados tenha sido muito pequeno, observou-se fenômeno equivalente, com diminuição de células $\mathrm{CD}^{\circ} 0^{+}$. Embora inconclusivos, esses dados sugerem a possibilidade de modulação recíproca dessas moléculas. Assim, pudemos obter a transfecção eficiente de DCs com siRNAs de interesse e, através deles, modular a expressão de CD80 e CD86. Com estes instrumentos, portanto, podemos agora desenvolver estudos quanto ao papel de cada uma destas moléculas na fisiologia da apresentação antigênica pelas DCs.

Palavras-chave: Células dendríticas. Moléculas co-estimuladoras. CD80. CD86. RNA de interferência. Imuno-modulação. 


\begin{abstract}
MIGLIORI, I. K. Use of small interfering RNA (siRNA) for modulating the expression of costimulatory molecules CD80 and CD86 on dendritic cells. 2010. 101 p. Master thesis (Immunology) - Instituto de Ciencias Biomédicas, Universidade de São Paulo, São Paulo, 2010.
\end{abstract}

The costimulatory molecules CD80 and CD86, expressed on surface of dendritic cells (DCs), are essential to trigger $\mathrm{T}$ cell activation and to maintain self tolerance, indicating that these molecules are promising therapeutic targets. They can either bind to CD28 on T cells, promoting $\mathrm{T}$ cell activation and leading to their proliferation and cytokine production, or to CTLA-4, which is expressed following T cell activation, and can inhibit $\mathrm{T}$ cell response. Though CD80 and CD86 are thought to provide equivalent $T$ cell costimulation, a growing body of evidence suggests that there are different functional consequences of CD28 engagement by these two molecules. Many reports point to variations in their ability to stimulate different lymphocyte subsets. However, there is still controversy in the literature and the actual role of CD80 and CD86 remains to be elucidated. Therefore, the aim of this study was to establish the methodology necessary to silence, by small interfering RNAs (siRNAs), both CD80 and CD86 expression on monocyte-derived dendritic cells. These findings would be the base of studys that could better elucidate the function of these two coestimulatory molecules in T cell activation. Therefore, transfection of $4^{\text {th }}$ day DCs with fluorescent siRNA and lipidic transfection agents SiPORT and IMAX was established, and transfection efficiency observed was $64,7 \% \pm 5,2$ e $69,7 \% \pm 14,5 \%$, respectively. $4^{\text {th }}$ day DCs were transfected with specific CD80 siRNAs and phenotype was observed after 48 hours of transfection. Besides CD80 efficient silencing by two from three siRNAs tested, there was an unexpected decrease in $\mathrm{CD}^{+} 6^{+}$cells. To establish CD86 silencing, CD14 ${ }^{+}$cells were positively selected with magnetic beads and immediately transfected with CD86 specific siRNAs, activated after 24 hours of transfection, and phenotype was observed after 24 hours of activation. Despite the fact that silencing conferred by one of two siRNAs was very low, equivalent phenomenon was observed, with a decrease in $\mathrm{CD}^{+} 0^{+}$cells. Although the observed effects were inconclusive, these data suggests a possible reciprocal modulation by these two molecules. Therefore, we were able to obtain efficient DC transfection with siRNAs of interest, as well as modulate CD80 and CD86 expression. With these 
instruments we can now develop studies regarding the real physiological role of these two costimulatory molecules in DCs antigen presentation.

Key words: Dendritic cells. Costimulatory molecules. CD80. CD86. Small interfering RNA. Immune modulation. 


\section{LISTA DE ILUSTRAÇÕES}

Figura 1 - Esquema indicativo da linha do tempo dos ensaios de transfecção de iDCs e monócitos

Figura 2 - Fotografia da eletroforese em gel de agarose do produto de extração de RNA total

Figura 3 - Curvas de dissociação dos primers obtidas por PCR em tempo real

Figura 4- Método de análise de monócitos, células dendríticas imaturas e maduras

Figura 5 - Gráficos pseudocoloridos do controle de células mortas marcadas com anexina e/ou PI

Figura 6 - Gráficos pseudo-coloridos indicando a pureza das células CD14 ${ }^{+}$após seleção positiva com beads magnéticas

Figura 7 - Fotomicrografias de uma cultura nos dias zero, cinco e sete e histogramas de CD14, HLA-DR e CD80 de monócitos (Mo), células dendríticas imaturas (iDCs) e maduras (mDCs)

Figura 8 - Fenótipo de monócitos, células dendríticas imaturas e maduras

Figura 9 - Intensidade mediana de fluorescência (MFI) de monócitos, células dendríticas imaturas e maduras

Figura 10 - Cinética da expressão dos mRNAs de CD80 e CD86 e correlação com expressão na superfície

Figura 11 - Efeito do tratamento com siPORT sobre a distribuição morfológica de células do sexto dia de cultura 
Figura 12 - Eficiência de transfecção de células dendríticas do sexto dia de cultura com o agente de transfecção siPORT

Figura 13 - Eficiência de transfecção de células dendríticas do quarto dia de cultura com o agente de transfecção siPORT

Figura 14 - Técnica de imunofluorescência para visualização da transfecção de células dendríticas imaturas do quarto dia de cultura com siRNA

Figura 15- Avaliação da viabilidade celular após tratamentos por exclusão do corante Azul de Tripan

Figura 16 - Avaliação do silenciamento de CD80 e CD86 em DCs após 48 da transfecção com siRNAs

Figura 17 - Eficiência de transfecção de células dendríticas do quarto dia de cultura com o agente de transfecção iMAX

Figura 18 - Avaliação da citotoxicidade do tratamento por marcação com anexina-PI e exclusão do corante Azul de Tripan

Figura 19 - Silenciamento de CD80 em DCs após 48 da transfecção com siRNAs

Figura 20 - Histogramas da expressão de CD80 e CD86 em DCs 48 horas após tratamento com siRNAs

Figura 21 - Expressão relativa de CD80, CD86, HLA-DR e CD83 por PCR em tempo real em DCs 48 horas após tratamento com siRNAs

Figura 22 - Silenciamento de CD86 em monócitos após 48 horas da transfecção com siRNAs 
Figura 23 - Histogramas da expressão de CD80 e CD86 em Mo 48 horas após tratamento com siRNAs 


\section{LISTA DE TABELAS}

Tabela 1 - Seqüências, números de identificação e designações dos SiRNAs

Tabela 2 - Seqüências dos primers utilizados nas reações de PCR em tempo real

Tabela 3 - Dados referentes aos anticorpos murinos usados para citometria de fluxo

Tabela 4 - Porcentagem de células transfectadas com diferentes quantidades de siPORT e concentrações de siRNA 


\section{LISTA DE ABREVIATURAS E SIGLAS}

\begin{tabular}{|c|c|}
\hline ANOVA & Análise de variância \\
\hline APCs & Células apresentadoras de antígenos \\
\hline BSA & Albumina bovina do soro \\
\hline CD & Cluster of diferentiation \\
\hline cDNA & DNA complementar \\
\hline Ct & Threshold cicle \\
\hline CTLA-4 & Antígeno 4 associado a linfócitos T citotóxicos \\
\hline CTLs & Células T citotóxicas \\
\hline DAPI & 4',6-diamidino-2-fenilindol \\
\hline DCs & Células dendríticas \\
\hline DEPC & Água tratada com dietil dicarbonato \\
\hline DNA & Ácido desoxirribonucléico \\
\hline dNTPs & Desoxirribonucleotídeos trifosfatados \\
\hline dsRNAs & RNAs dupla-fita \\
\hline DTT & Ditiotreitol \\
\hline EDTA & Etilenodiaminotetracético \\
\hline FSC & Foward scatered \\
\hline GAPDH & Gliceraldeído 3-fosfato desidrogenase \\
\hline GM-CSF & Fator de crescimento de colônia de granulócito e macrófago \\
\hline HLA-DR & Antígeno leucocitário humano-DR \\
\hline iDCs & Células dendríticas imaturas \\
\hline IFN-Y & Interferon- $\vee$ \\
\hline IL & Interleucina \\
\hline iRNA & RNA de interferência \\
\hline Lin & Lineage \\
\hline LPS & Lipopolissacarídeo \\
\hline mAbs & Anticorpos monoconais \\
\hline mDCs & Células dendríticas maduras \\
\hline MFI & Intensidade mediana de fluorescência \\
\hline MHC & Complexo principal de histocompatibilidade \\
\hline
\end{tabular}




\begin{tabular}{|c|c|}
\hline miRNAs & Micro-RNAs \\
\hline Mo & Monócitos \\
\hline mRNAs & RNAs mensageiro \\
\hline ncRNAs & RNAs não codificantes \\
\hline NOD & Diabéticas não obesas \\
\hline OAS & Oligoadenilato sintetase \\
\hline PAMP & Padrões moleculares associados a patógenos \\
\hline PBMCs & Células mononucleares do sangue periférico \\
\hline PBS & Solução salina tamponada com fosfato \\
\hline PCR & Reação em cadeia da polimerase \\
\hline PGE-2 & Prostaglandina E2 \\
\hline PI & lodeto de propídeo \\
\hline PKR & Proteína quinase dependente de RNA \\
\hline RISC & Complexo de silenciamento induzido por RNA \\
\hline RNA & Ácido ribonucléico \\
\hline RPMI & Meio roswell park memorial institute \\
\hline RT & Transcrição reversa \\
\hline Scr & Scrambled \\
\hline SFB & Soro fetal bovino \\
\hline shRNAs & Short hairpin RNAs \\
\hline siRNAs & RNAs pequenos de interferência \\
\hline SSC & Side scatered \\
\hline TCR & Receptor de células T \\
\hline Th1 & Linfócitos T auxiliares 1 \\
\hline Th2 & Linfócitos T auxiliares 2 \\
\hline TLR3 & Receptor tipo Toll-3 \\
\hline TNF $\alpha$ & Fator de necrose tumoral $\alpha$ \\
\hline Tregs & Linfócitos $\mathrm{T}$ reguladores \\
\hline
\end{tabular}




\section{SUMÁRIO}

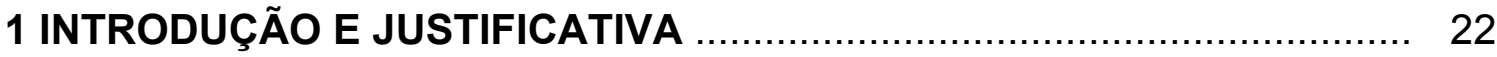

1.1 Célula dendrítica e moléculas co-estimuladoras CD80 e CD86 ........ 23

1.2 RNAs pequenos de interferência (siRNAs) …........................... 27

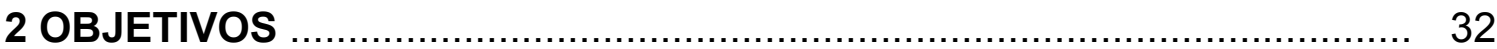

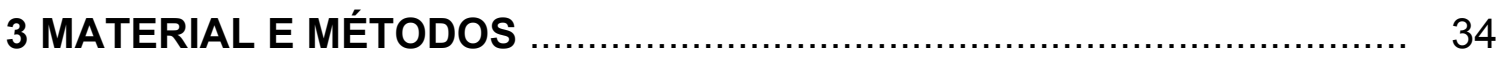

3.1 Casuística ............................................................................... 35

3.2 Diferenciação in vitro de DCs a partir de monócitos de sangue

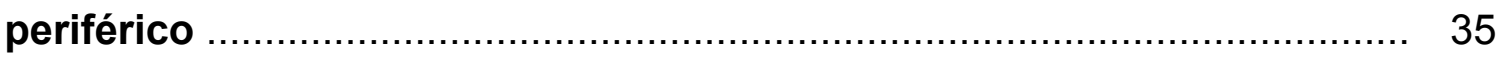

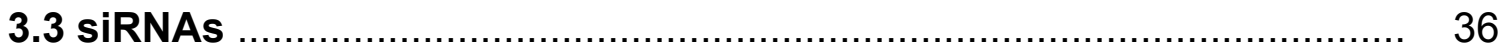

3.4 Transfecção das células com siRNAs ......................................... 37

3.5 Extração de RNA total ............................................................ 39

3.6 Transcrição reversa, PCR e PCR em tempo real ........................... 40

3.6.1 Desenho dos primers ........................................................ 41

3.6.2 Análise dos resultados de PCR em tempo real ................................ 42

3.7 Análise fenotípica por citometria de fluxo .................................... 44

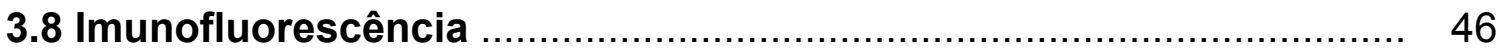

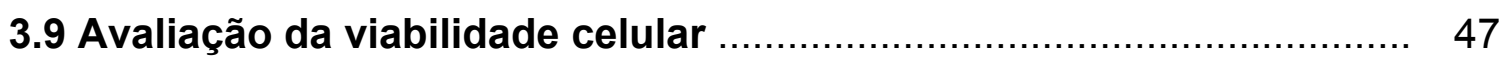

3.9.1 Por exclusão do Azul de Tripan .............................................. 47

3.9.2 Por marcação com anexina e iodeto de propídeo (PI) ........................ 47

3.10 Seleção positiva de células CD14+ por beads magnéticas ............. 48

3.11 Análise estatística .................................................... 49

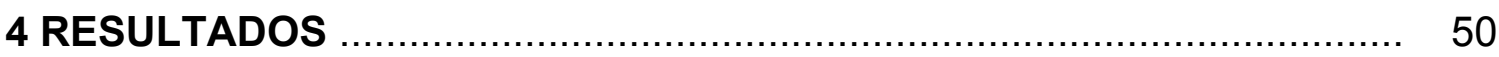

4.1 Caracterização fenotípica de monócitos, DCs imaturas e maduras .. 51 
4.2 Cinética de expressão de mRNA das moléculas CD80 e CD86

4.3 Padronização da transfecção de iDCs com siRNA marcado

4.4 Utilização de siPORT para silenciamento das moléculas CD80 e CD86

4.4.1 Avaliação da viabilidade celular 65

4.4.2 Ausência de silenciamento das moléculas CD80 e CD86 66

4.5 Utilização de iMAX para silenciamento das moléculas CD80 e CD86 67

4.5.1 Avaliação da eficiência de transfecção 68

4.5.2 Avaliação da viabilidade celular 69

4.5.3 Silenciamento de CD80 71

4.5.4 Silenciamento de CD86 74

5 DISCUSSÃO 77

6 CONCLUSÕES 82

REFERÊNCIAS 84

ANEXO 94

ANEXO - Termo de Consentimento Livre e Esclarecido 95 


\section{INTRODUÇÃO E JUSTIFICATIVA}




\subsection{Célula dendrítica e moléculas co-estimuladoras CD80 e CD86}

As moléculas CD80 (B7-1) e CD86 (B7-2) são provavelmente as moléculas co-estimuladoras mais bem caracterizadas, sendo expressas predominantemente na superfície das células apresentadoras de antígeno profissionais (APCs) (células dendríticas - DCs, macrófagos e linfócitos B ativados), bem como de linfócitos $\mathrm{T}$ ativados (HATHCOCK et al., 1994; STACK et al., 1994). A participação destas moléculas na modulação imune por linfócitos $T$ constitui, possivelmente, uma das vias de comunicação celular mais relevantes, atuando tanto na indução de resposta quanto na manutenção de tolerância (GREEN et al., 1994; WALUNAS et al., 1994; RADVANYI et al., 1996; BANCHEREAU e STEINMAN, 1998; WALUNAS e BLUESTONE, 1998; LUTZ e SCHULER, 2002). Por esse motivo, tais moléculas são consideradas alvos terapêuticos promissores (GUINAN et al., 1994; LANG et al., 2002).

Há evidências de que a ligação dessas moléculas ao receptor CD28, presente na superfície dos linfócitos $T$, em adição à ligação do receptor de célula T (TCR) antígeno-específico ao conjunto complexo principal de histocompatibilidade (MHC)peptídeo, leva à ativação e proliferação dos linfócitos $T$, produção de citocinas, e previne a indução de anergia celular (HARDING et al., 1992; LENSCHOW et al., 1996; MANZOTTI et al., 2006). CD80 e CD86 também compartilham a ligação ao receptor CTLA-4 (antígeno 4 associado a linfócitos T citotóxicos, CD152) dos linfócitos $T$ ativados, o que se acredita resultar na inibição de resposta pelas células T, contribuindo para o controle da resposta imune (GREENWALD et al., 2005).

Apesar das moléculas CD80 e CD86 possuírem funções semelhantes, existem diferenças quanto à expressão dessas nas APCs, e quanto à sua afinidade pelos receptores CD28 e CTLA-4. CD86 possui expressão constitutiva em baixos níveis em monócitos, células dendríticas e linfócitos $B$ em repouso, que é rapidamente aumentada após a ligação APC-linfócito $\mathrm{T}$, enquanto que a expressão de CD80 é induzida e ocorre posteriormente ao aumento de expressão de CD86. Além disso, existem evidências de que as moléculas CD80 e CD86 possuem maior afinidade pelo receptor CTLA-4 que pelo CD28 (HATHCOCK et al., 1994; LARSEN et al., 1994), e que CD80 se ligue a ambos os receptores mais avidamente que CD86 (LINSLEY et al., 1994). 
Além das diferenças relacionadas à cinética de ligação de CD80 e CD86 aos seus receptores, um número relevante de estudos tem questionado a equivalência dos efeitos co-estimuladores gerados por estas duas moléculas, com resultados contrastantes quanto ao papel funcional desempenhado por CD80 e CD86 na ativação de células $\mathrm{T}$, ao padrão de resposta desencadeado e à capacidade de ativação de células $T$, sugerindo diferenças de natureza qualitativa e quantitativa entre as duas moléculas (FIELDS et al., 1998; BOYLAN et al., 1999; LANG et al., 2002; XIANG et al., 2008).

Alguns estudos envolvendo modelos murinos ou seres humanos sugerem que CD80 tenha maior capacidade co-estimuladora de ativação de células T que CD86, como mensurado por ensaios proliferativos, produção de citocinas, indução de citólise e rejeição de certos tumores (GAJEWSKI, 1996; GAJEWSKI et al., 1996; MATULONIS et al., 1996; VAN DIJK et al., 1996). Um estudo em modelo murino, por sua vez, utilizando ensaios in vitro e in vivo, por meio da metodologia de RNA de interferência, indicou maior eficiência co-estimuladora da molécula CD86 (XIANG et al., 2008). Ainda, há relatos indicando equivalência de CD80 e CD86 na iniciação e manutenção da proliferação de células $\mathrm{T}^{\mathrm{CD}} 4^{+}$em modelo experimental in vitro (VASILEVKO et al., 2002).

De qualquer modo, a importância dessa via de co-estimulação na ativação de células $\mathrm{T}$ é suportada por uma série de experimentos. Experimentos in vivo revelaram não apenas a relevância das moléculas co-estimuladoras na ativação de células T e manutenção de tolerância, mas também a possibilidade de modulação dessas moléculas com vistas à imunoterapia. Em diversos modelos animais de doenças e em seres humanos, em que a ativação das células T é crítica (diabetes melitus, lupus eritematoso sistêmico, encefalomielite auto-imune experimental e rejeição de enxerto, por exemplo), demonstraram-se benefícios do bloqueio de CD80 e CD86, pois este impediria a ativação dos linfócitos T virgens pelas APCs (LIN et al., 1993; FINCK et al., 1994; CROSS et al., 1995; KHOURY et al., 1995; LENSCHOW et al., 1995a; LENSCHOW et al., 1995b). Exemplificando bem este papel das moléculas CD80 e CD86, vale ressaltar um estudo, que reporta o efeito do bloqueio destas moléculas em transplante alogenêico pancreático em camundongos. Neste estudo, a terapia combinada de anticorpos monoclonais (mAbs) anti-CD80 e anti-CD86 retardou a infiltração de linfócitos $T \mathrm{CD}^{+}$no enxerto, e conseqüentemente sua rejeição (LENSCHOW et al., 1995b). 
Ainda, há estudos na literatura indicando que a diferenciação das células $T$ $\mathrm{CD}^{+}$auxiliares (Th) para os padrões de resposta Th1 ou Th2 sofre influência dos níveis de expressão de CD80 e/ou CD86 das APCs. Boa parte dos relatos indica que CD80 promove uma resposta mais voltada ao padrão Th1, enquanto CD86 promove uma resposta mais voltada ao padrão Th2 (FREEMAN et al., 1995; KUCHROO et al., 1995; RANGER et al., 1996). Num relato, a injeção de mAb antiCD80 em camundongos com encefalomielite auto-imune experimental, modelo de doença mediada por um padrão Th1 de resposta, reduziu significativamente a severidade da doença por mudar o padrão de produção de citocinas para o padrão Th2, enquanto a injeção de mAb anti-CD86 tornou-a mais grave (KUCHROO et al., 1995; RACKE et al., 1995). Outros autores, em modelos de camundongos knockout para CD80 e/ou CD86 também reportaram efeito patogênico de CD80 em glomerulonefrite progressiva, por aumento de proliferação e sobrevivência de células $\mathrm{T} \mathrm{CD}^{+}$, enquanto CD86 revelou efeito protetor para a mesma doença por aumento de resposta com padrão Th2 em detrimento de Th1 (ODOBASIC et al., 2005).

Todavia, este envolvimento da sinalização via CD80 com a resposta de padrão Th1 nem sempre ocorre. Por exemplo, no modelo de diabetes auto-imune experimental em camundongos fêmeas diabéticas não obesas (NOD), em que também o fenótipo Th1 predomina, o bloqueio seletivo de CD80 com mAb acelerou o desenvolvimento da doença, além de induzir diabetes em machos normalmente resistentes. Por outro lado, fêmeas NOD tratadas no início do processo de insulite com mAbs anti-CD86 não desenvolveram diabetes, indicando que CD86 era a molécula co-estimuladora principal na resposta Th1 (LENSCHOW et al., 1995a).

Acrescentando mais um grau de complexidade à fisiologia destas moléculas, outro estudo empregando camundongos knockout para CD80 ou CD86 não revelou funções distintas de CD80 e CD86 com relação ao padrão de resposta Th1/Th2 observado nos animais (SCHWEITZER et al., 1997).

Outro ponto onde a participação de CD80 e CD86 na ativação de linfócitos T parece indicar diferenças funcionais entre ambas as moléculas, ocorre na indução de resposta de linfócitos $\mathrm{T} \mathrm{CD}^{+}$e $\mathrm{T} \mathrm{CD8} 8^{+}$. Estudos in vivo utilizando o modelo murino de doença enxerto-versus-hospedeiro mostraram que o bloqueio de CD86 com mAbs inibe a ativação de células $\mathrm{T} \mathrm{CD4}^{+}$, enquanto que mAbs anti-CD80 potencializam a ativação de células $\mathrm{T} C D 8^{+}$. Este estudo aponta para um papel crítico de CD86 na ativação e diferenciação de células $T \mathrm{CD}^{+}$, tanto para uma 
resposta com padrão Th1 quanto Th2, e CD80 seria fundamental para controlar a ativação de células T $\mathrm{CD}^{+}$(LANG et al., 2002). Um estudo recente, porém, utilizando modelo murino in vivo apontou para um papel fundamental de CD86 na indução de linfócitos T CD8 específicos contra o vírus vaccinia sem necessidade de co-estimulação por CD80, sugerindo que CD80 e CD86 podem ser diferencialmente utilizados em respostas antivirais (SALEK-ARDAKANI et al., 2009).

Há ainda um relato indicando que as células $T$ virgens respondem à coestimulação de maneira diferente das células sensibilizadas. De acordo com este estudo, CD80 promoveu co-estimulação maior que CD86 em células T CD8 ${ }^{+}$ virgens, com maior proliferação celular e produção de IL-2. Em contraste, células T $\mathrm{CD}^{+}$sensibilizadas responderam ao co-estímulo de CD80 e CD86 de maneira quantitativamente similar (FIELDS et al., 1998).

Outro foco de estudo, pouco avaliado nos estudos citados, é o papel exercido pelas moléculas co-estimuladoras CD80 e CD86 na modulação da resposta via ativação de células $T$ reguladoras (Tregs). Um estudo, com utilização de células humanas, mostrou que CD80 e CD86 possuem funções opostas na ligação a CD28 e CTLA-4 nas Tregs. De acordo com este estudo, o bloqueio de CD86 inibiu a resposta de células $\mathrm{T} \mathrm{CD4}^{+}$, enquanto que o bloqueio de CD80 aumentou essa resposta, de modo que o efeito inibidor requeriu a presença de células $T$ $\mathrm{CD} 4^{+} \mathrm{CD} 25^{+}$. Com a remoção das mesmas, a supressão foi prevenida (ZHENG et al., 2004).

É possível que muitos dos resultados discordantes mencionados tenham sido obtidos pela variedade de modelos/sistemas utilizados (FIELDS et al., 1998), o que reforça a necessidade de um maior esclarecimento sobre a atuação de CD80 e CD86 na modulação da resposta imune. Em particular, é de grande interesse o entendimento do papel dessas moléculas na interação específica da célula dendrítica com os linfócitos $T$, uma vez que esta interação tem um papel fundamental na determinação da resposta imune (STEINMAN, 2007).

Provavelmente, o maior interesse na compreensão da verdadeira função de CD80 e CD86 esteja voltado ao estudo do câncer. É proposto que a falta de imunogenicidade de muitos tipos tumorais possa ser devido à diminuição de expressão de CD80 e CD86 pelas células dendríticas (CHAUX et al., 1996; THURNHER et al., 1996; GABRILOVICH et al., 1997; HASEBE et al., 2000; DELLA BELLA et al., 2003; ORSINI et al., 2003; DELLA BELLA et al., 2006), o que levaria à 
apresentação ineficiente de antígenos pelas DCs e conseqüente progressão tumoral (CHAUX et al., 1996; ISHIDA et al., 1998).

Embora haja relatos contraditórios (PREYNAT-SEAUVE et al., 2006), a maior parte das observações sugere que os defeitos funcionais nas DCs intra-tumorais se manifestam também em DCs diferenciadas in vitro, a partir de monócitos do sangue periférico de pacientes com câncer (NEVES et al., 2005; BALEEIRO et al., 2008). É interessante notar que, muito freqüentemente, como ocorreu em nosso estudo (NEVES et al., 2005) e em outros atualmente em curso no laboratório (dados não publicados), a alteração mais nítida nas DCs derivadas de monócitos de pacientes com câncer, se dá na expressão relativa das moléculas CD80 e CD86. Além do mais, outra observação relevante, foi a "recuperação" da expressão destas moléculas após o tratamento imunoterapêutico dos pacientes (BARBUTO et al., 2004; NEVES et al., 2005), sugerindo que o equilíbrio de expressão destas moléculas seja um indicador de "saúde imunológica" do indivíduo. Esta compreensão permitiria aperfeiçoar abordagens que procuram utilizar as DCs para imunoterapia de condições tão variadas quanto doenças auto-imunes, rejeição de aloenxertos, doença enxerto-versus-hospedeiro e câncer, refletindo também a grande heterogeneidade das DCs (HARTGERS et al., 2000; STEINMAN e BANCHEREAU, 2007).

\subsection{RNAs pequenos de interferência (siRNAs)}

Há algum tempo, os RNAs eram considerados moléculas acessórias do genoma, uma vez que tinham sua função atrelada diretamente à síntese de proteínas. Além disso, acreditava-se que a complexidade do genoma era resultado de um maior número de genes codificadores de proteínas. Na década de 70 , com a descoberta de que muitos dos transcritos primários possuíam seqüências não codificadoras (íntrons) entre as seqüências codificadoras (éxons), e que, por splicing alternativo, mais de uma proteína poderia ser formada a partir de um mesmo mRNA primário, percebeu-se que os RNAs exerciam outras funções, e não somente um papel passivo no processo de tradução. Descobriu-se, há mais de vinte anos, as propriedades catalíticas do RNA, e o seqüenciamento genômico também contribuiu para a noção de que muito da complexidade dos organismos está na capacidadade 
reguladora dos RNAs não codificadores (ncRNAs), e não apenas nas regiões codificadoras (SZYMANSKI e BARCISZEWSKI, 2002).

Os ncRNAs estão envolvidos em vários processos, tais como regulação transcricional, pós-transcricional, replicação cromossômica, imprinting genômico, processamento do RNA, splicing alternativo, estabilidade e tradução do mRNA e degradação protéica. Os principais ncRNAs pequenos, que possuem de 19-31 nucleotídeos, envolvidos na regulação da expressão gênica em células eucarióticas em nível pós-transcricional, são os micro-RNAs (miRNAs) e RNAs pequenos de interferência (siRNA). (MATTICK e GAGEN, 2001; MATTICK, 2004; CHU e RANA, 2007). Essas duas classes de RNAs são distinguidos uma da outra não por seu tamanho ou função, mas sim pela sua origem. Os miRNAs são processados a partir de estruturas primárias em forma de hairpins, que após clivagem produzem os short hairpin RNAs (shRNAs), enquanto que os siRNAs são produto de clivagem de longos RNAs dupla-fita (dsRNAs). Ambos possuem o mesmo potencial regulador, influenciado pela complementariedade com que se ligam ao mRNA alvo. Hoje se sabe que possuem a capacidade de desencadear a degradação do mRNA alvo, ou por clivagem no caso de pareamento por complementariedade perfeito ou quase perfeito ao mRNA alvo, ou por acelerar a remoção das cadeias poli(A) no caso de pareamento imperfeito (WU e BELASCO, 2008).

Os miRNAs foram descobertos por Ambros e colaboradores em 1993 como um regulador endógeno que controla o desenvolvimento em Caenorhabditis elegans. Cinco anos mais tarde, Fire, Mello e colaboradores descreveram que dsRNAs exógenos silenciavam genes de maneira específica, por um mecanismo denominado RNA de interferência (iRNA). Em 1999, o silenciamento em plantas mostrou-se acompanhado do aparecimento de RNAs de 20-25 nucleotídeos de seqüência homóloga ao mRNA alvo. Logo depois, documentou-se a conversão direta de dsRNAs em siRNAs de 21-23 nucleotídeos. Não tardou para que se percebesse que esses RNAs reguladores pequenos, amplamente distribuídos pelos eucariotos por mecanismos conservados, poderiam servir como uma potente ferramenta com inúmeras aplicações, uma vez que a célula possui toda a maquinaria necessária para o silenciamento (CARTHEW e SONTHEIMER, 2009).

O mecanismo biológico pelo qual miRNAs ou siRNAs desencadeiam o silenciamento gênico envolve um processo de duas etapas. Após deixarem o núcleo e penetrarem no citoplasma, os dsRNAs ou shRNAs são reconhecidos pela enzima 
Dicer, clivando-os em fragmentos menores (21-23 nucleotídeos), os quais passam a ser chamados de siRNAs ou miRNAs, respectivamente. Esses são então incorporados em um componente multi-protéico denominado complexo de silenciamento induzido por RNA (RISC). A fita líder permanece acoplada ao complexo, enquanto a fita passageira é degradada. O mRNA, ao parear de maneira perfeita ou quase perfeita à fita líder, sinaliza para a clivagem do mRNA ao meio. $O$ mRNA clivado produzirá duas fitas com um dos terminais desprotegidos, ou pela ausência do CAP, ou pela ausência da cauda poli(A), os quais são suscetíveis ao ataque por uma exonuclease, resultando no silenciamento do mRNA alvo (WU e BELASCO, 2008).

O silenciamento gênico em células de mamíferos tem sido obtido através da transfecção com siRNAs sintéticos, os quais, ao penetrarem no citoplasma, são incorporados ao RISC e desencadeiam o processo descrito. Já a transfecção de células com dsRNAs, ou com vetores de expressão, que resultam na síntese de shRNAs, produzem miRNAs ou siRNAs sob ação da enzima Dicer, os quais podem então se complexar ao RISC e, novamente, desencadear o silenciamento (CAMPBELL e CHOY, 2005).

Embora seja inegável a importância da utilização do processo de iRNA como ferramenta em campos de pesquisa básica e aplicada (genômica funcional, identificação de alvos moleculares, elucidação de vias de sinalização e do potencial em aplicações clínicas em doenças metabólicas, câncer, AIDS, malária, etc.), há relatos na literatura que apontam para dificuldades funcionais e/ou efeitos não desejados, salientando que ainda tem-se muito a aprender nesse novo campo da pesquisa (PUSHPARAJ et al., 2008; OLEJNICZAK; GALKA; KRZYZOSIAK, 2009). A detecção do efeito produzido por iRNA em células somáticas de mamíferos têm sido dificultada pela presença de um mecanismo dependente de dsRNA que leva à supressão da expressão gênica de maneira não específica. Isso ocorre pois a introdução de dsRNAs em células de mamíferos desencadeia um processo inespecífico de bloqueio da transcrição e tradução, como conseqüência evolutiva contra infecção das células por vírus.

Os dsRNAs são indutores da síntese de IFNs tipo I, que por sua vez induzem a proteína quinase dependente de RNA (PKR) e a 2'-5'-oligoadenilato sintetase (OAS). A ativação da PKR leva à fosforilação e à inativação do fator elF2 $\alpha$. Já a ativação da OAS causa a conversão de ATP em 2'-5'-oligoadenilatos de diversos 
tamanhos, causando a ativação da RNAse L, que é uma endonuclease envolvida na degradação de RNA. Essas seqüências de eventos levam à inibição geral da síntese protéica e por fim à apoptose celular. Ainda, há outros receptores que podem ser ativados pela presença de RNAs. Demontrou-se que o receptor tipo Toll-3 (TLR-3), cujo papel biológico é reconhecer dsRNAs virais tanto no citoplasma quanto na superfície celular, pode ser ativado in vivo por siRNAs exógenos seqüênciaindependentes de pelo menos 21 nucleotídeos de comprimento, levando à produção de IFN-Y e IL-12. Já os receptores TLR-7 e TLR-8, presumivelmente expressos nos endossomos das células imunes, reconhecem RNAs aprisionados nessas vesículas de maneira seqüência-dependente. Esses receptores, que foram primariamente descritos por sua capacidade em reconhecer RNAs de fita simples (ssRNAs), mas que também têm o potencial de reconhecer dsRNAs pequenos, são sensíveis a domínios ricos em uracilas e guaninas. Dependendo de sinal transmitido por esses receptores, pode ocorrer expressão de IFN- $\alpha$ e outras citocinas inflamatórias. Há ainda outros receptores descritos, cuja ativação foi dependente do comprimento do siRNA, estrutura, constituição da seqüência e concentração (MARQUES e WILLIAMS, 2005; OLEJNICZAK; GALKA; KRZYZOSIAK, 2009).

Visando o emprego da tecnologia do iRNA em estudos básicos e clínicos, há ainda outros fontes de obstáculos a serem superados. Além do recém mencionado efeito de ativação de receptores celulares capazes de reconhecer padões moleculares associados a patógenos (PAMPs), com conseqüente bloqueio da síntese protéica, apoptose celular e produção de citocinas inflamatórias, há ainda a descrição de outros efeitos indesejados. Dentre eles pode-se mencionar a saturação de proteínas celulares envolvidas na via de silenciamento, levando a um silenciamento ineficaz, assim como efeitos off-target, ou seja, silenciamento não desejados de transcritos de maneira inespecífica (OLEJNICZAK; GALKA; KRZYZOSIAK, 2009).

Até o presente, dois estudos, utilizando DCs murinas derivadas da medula óssea, se valeram da tecnologia de iRNA para suprimir a expressão de CD80 e CD86 in vitro (GU et al., 2006; XIANG et al., 2008). No estudo de Gu et al. (2006), a técnica foi capaz de, especificamente e efetivamente, suprimir a expressão de CD80 e CD86 em cerca de 70\%. Xiang et al. (2008), além da utilização de ensaios in vitro para avaliar as diferenças funcionais entre CD80 e CD86 em DCs, avaliaram in vivo 
o efeito da supressão de CD80 e/ou CD86 na sobrevivência de aloenxerto cardíaco em murinos. Neste estudo, em que animais receberam DCs silenciadas ou não sete dias antes do transplante cardíaco, indicou-se que CD86 possui capacidade coestimuladora mais eficiente que CD80, com aumento de produção de IFN- $\gamma$, diminuição de produção de IL-10 e maior capacidade de rejeição de enxerto.

Em conclusão, portanto, torna-se claro o valor da compreensão do papel destas moléculas na interação bidirecional entre as DCs e os linfócitos T. Por um lado, a grande heterogeneidade das DCs e seu papel central na indução da resposta de linfócitos $T$ virgens podem depender, entre outros fatores, da expressão diferenciada das moléculas CD80 e CD86, o que confere à descrição de seu papel nestas interações um significado ímpar. Por outro lado, a modulação da expressão destas duas moléculas, baseada na compreensão de seu papel biológico, poderia tornar-se maneira muito efetiva de controlar e dirigir a resposta imune em diversas situações clínicas. Resolvemos, portanto, investigar a possibilidade de silenciamento destas duas moléculas em células dendríticas humanas diferenciadas a partir de monócitos de sangue periférico, utilizando a tecnologia do RNA de interferência, para eventualmente, dispormos de ferramenta capaz de elucidar o papel das mesmas na fisiologia das DCs. 
2 OBJETIVOS 
O objetivo último de nossa investigação é o de avaliar o papel das moléculas co-estimuladoras CD80 e CD86 expressas por células dendríticas, na ativação de linfócitos T humanos.

Para tanto, procuramos, no presente trabalho, estabelecer metodologia capaz de suprimir especificamente a expressão de CD80 e CD86 por monócitos e células dendríticas imaturas, diferenciadas in vitro a partir de monócitos humanos, obtidos de sangue periférico de doadores saudáveis, através da utilização de siRNAs específicos para os mRNAs destas duas moléculas. 
3 MATERIAL E MÉTODOS 


\subsection{Casuística}

Este estudo foi submetido e aprovado pela Comissão de Ética em Pesquisa do Instituto de Ciências Biomédicas da Universidade de São Paulo (Parecer 834/CEP). Amostras de sangue periférico para obtenção de células mononucleares foram obtidas a partir de câmaras de leucorredução de plaquetas por aférese, de doadores saudáveis do Hospital Oswaldo Cruz, após a assinatura do Termo de Consentimento Livre e Esclarecido.

\subsection{Diferenciação in vitro de DCs a partir de monócitos de sangue periférico}

Monócitos foram separados de células mononucleares do sangue periférico (PBMCs), obtidas a partir de câmaras de leucorredução. Para a purificação das células mononucleares, o conteúdo das câmaras foi diluído em solução salina tamponada c fosfato (PBS) (1:1) e colocado em tubos plásticos cônicos de $50 \mathrm{~mL}$, aos quais foram acrescentados, no fundo do tubo, $12 \mathrm{~mL}$ de Ficoll-Paque Plus (GE Healthcare). $\mathrm{O}$ material foi centrifugado a $900 \mathrm{~g}$ a $18^{\circ} \mathrm{C}$ por 30 minutos. A camada de células mononucleares formada foi retirada, colocada em outro tubo juntamente com RPMI-1640 e centrifugada a $600 \mathrm{~g}$ por 10 minutos. As células foram lavadas por mais duas vezes a 300 e a $200 \mathrm{~g}$, respectivamente. O botão celular foi coletado, as células quantificadas, ressuspendidas em meio RPMI-1640 e colocadas em cultura na concentração de $10^{7}$ células $/ \mathrm{mL}$. As células foram mantidas na estufa para a aderência a $37^{\circ} \mathrm{C}$ em atmosfera contendo $5 \%$ de $\mathrm{CO}_{2}$ e saturada de água por uma hora e trinta minutos.

Após a incubação, as células não aderentes presentes no sobrenadante foram removidas, quantificadas e congeladas para possíveis ensaios posteriores. As células aderentes foram mantidas em cultura por cinco dias em meio AIM-V ou RPMI-1640 suplementado com $10 \%$ de soro fetal bovino (SFB), a depender dos objetivos do experimento, acrescido de $50 \mathrm{ng} / \mathrm{mL}$ de IL-4 e $50 \mathrm{ng} / \mathrm{mL}$ de GM-CSF para a diferenciação dos monócitos em DCs. Após esse período, as células foram ativadas pela adição de $50 \mathrm{ng} / \mathrm{mL}$ de TNF- $\alpha$ ou, em alguns casos, coquetel de ativação (10 ng/mL de TNF- $\alpha, 10 \mathrm{ng} / \mathrm{mL}$ de $\mathrm{IL}-1 \beta, 10 \mathrm{ng} / \mathrm{mL}$ de $\mathrm{IL}-6$ e $1 \mu \mathrm{g} / \mathrm{mL}$ de PGE-2) ou $100 \mathrm{ng} / \mathrm{mL}$ de LPS e, no sétimo dia, estas foram removidas utilizando-se RPMI-1640 gelado e uma alíquota foi separada para contagem. Após centrifigação a 
1200 rpm por 10 minutos, as DCs maduras foram usadas em ensaios subseqüentes. No caso dos ensaios que envolveram a utilização de monócitos (dia zero) ou células dendríticas imaturas (quarto ou quinto dia da cultura), estes foram retiradas mecanicamente (com auxílio de êmbolo de seringa ou cell scraper).

\section{3 siRNAs}

Os siRNAs escolhidos para silenciamento da expressão das moléculas CD80 CD86 em células humanas foram desenhados, validados in silico e sintetizados pela Applied Biosystems, e são denominados Silencer $^{\circledR}$ Select Pre-designed siRNA. Foram testados três siRNAs para cada uma dessas moléculas. Um siRNA com seqüência nucleotídica aleatória (scrambled - scr) e sem especificidade a algum mRNA, portanto sem capacidade de silenciamento, também foi adquirido para utilização como controle negativo. As seqüências dupla-fita, números de identificação e designações correspondentes dos siRNAs estão descritos na Tabela 1. Como controle de transfecção, utilizou-se um siRNA para GAPDH conjugado ao fluorocromo Cy3 (GAPDH-Cy3), o qual é detectado pelo canal FL2 do citômetro de fluxo. 
Tabela 1 - Seqüências, números de identificação e designações dos siRNAs. Seqüências dos siRNAs dupla-fita testados para silenciamento da expressão das moléculas CD80 e CD86, e do controle negativo siRNA scrambled (Scr), números de identificação dessas seqüências e do controle positivo GAPDH-Cy3 (siRNA ID) e designações correspondentes utilizadas neste texto.

\begin{tabular}{|c|c|c|c|}
\hline $\begin{array}{l}\text { Especificidade } \\
\text { ao mRNA }\end{array}$ & $\begin{array}{l}\text { siRNA } \\
\text { ID }\end{array}$ & $\begin{array}{c}\text { Seqüências de nucleotídeos dos } \\
\text { siRNAs }\end{array}$ & Designação \\
\hline GAPDH & & Não fornecida & GAPDH-Cy3 \\
\hline - & $\# 1$ & $\begin{array}{l}\text { F5'-UAACGACGCGACGACGUAAtt-3' } \\
\text { R3'-ttAUUGCUGCGCUGCUGCAUU-5' }\end{array}$ & Scr \\
\hline CD80 & s2624 & $\begin{array}{l}\text { F5'-GCUGACUUCCCUACACCUAtt-3' } \\
\text { R3'-ttCGACUGAAGGGAUGUGGAU-5' }\end{array}$ & CD80-1 \\
\hline \multirow{5}{*}{ CD86 } & s2625 & $\begin{array}{l}\text { F5'-CAUCUUUGAUAUCACUAAUtt-3' } \\
\text { R3'-tgGUAGAAACUAUAGUGAUUA-5' }\end{array}$ & CD80-2 \\
\hline & s2626 & $\begin{array}{l}\text { F5'-CAUCAAGUAUGGACAUUUAtt-3' } \\
\text { R3'-agGUAGUUCAUACCUGUAAAU-5' }\end{array}$ & CD80-3 \\
\hline & s2627 & $\begin{array}{l}\text { F5'-GCACAAGUUUUGAUUCGGAtt-3' } \\
\text { R3'-ggCGUGUUCAAAACUAAGCCU-5' }\end{array}$ & CD86-1 \\
\hline & s2628 & $\begin{array}{l}\text { F5'-GAAUUCAACUAUCGAGUAUtt-3' } \\
\text { R3'-ttCUUAAGUUGAUAGCUCAUA-5' }\end{array}$ & CD86-2 \\
\hline & s2629 & $\begin{array}{l}\text { F5'-CGAGCAAUAUGACCAUCUUtt-3' } \\
\text { R3'-taGCUCGUUAUACUGGUAGAA-5' }\end{array}$ & CD86-3 \\
\hline
\end{tabular}

\subsection{Transfecção das células com siRNAs}

Para a transfecção das células com siRNAs utilizou-se a metodologia de transfecção reversa, geralmente recomendada para a transfecção de células aderentes. Utilizaram-se dois agentes de tranfecção lipídicos: siPORT ${ }^{\mathrm{TM}} \mathrm{NeoFX^{ \textrm {TM } }}$ Transfection Agent (Applied Biosystems) (siPORT) e Lipofectamine ${ }^{\text {TM }}$ RNAiMAX Transfection Reagent (Invitrogen) (iMAX). Para tanto, diluiu-se o agente de transfecção siPORT ou iMAX e o siRNA em meio Opti-MEM ${ }^{\circledR}$ I (Invitrogen), separadamente, para volume final de $100 \mu \mathrm{L}$. Utilizou-se a quantidade de $5 \mu \mathrm{L}$ de agente de transfecção, e siRNA para concentração final de $50 \mathrm{nM}$. As soluções foram incubadas por 10 minutos à temperatura ambiente. Após esta breve incubação, misturaram-se as soluções diluídas, com nova incubação por 30 minutos à temperatura ambiente, possibilitando a formação dos complexos de transfecção ou 
lipossomos. Estes são compostos lipídicos catiônicos que interagem com os siRNAs, de carga negativa, o que se acredita facilitar a entrada destes últimos por endocitose. As diferenças de cargas entre as membranas endossomais aniônicas e os lipossomos catiônicos desestabilizam as membranas do endossomo e facilitam o escape do siRNA para o citoplasma. Além disso, o pH baixo presente no interior dos lisossomos também contribui para a dissociação do siRNA de seus carregadores (OLEJNICZAK; GALKA; KRZYZOSIAK, 2010). Os complexos de transfecção, após formados, foram então dispensados em poços limpos da placa de cultura de 6 poços, e sobrepostos por $1 \times 10^{6}$ células/poço previamente retiradas da cultura no quarto dia, no caso da transfecção de iDCs, ou no dia zero da cultura, no caso da transfecção de monócitos, totalizando volume final de 1,5 mL/poço.

No caso das células diferenciadas em meio AIM-V (iDCs e monócitos), a transfecção foi integralmente realizada nesse meio. No caso das células diferenciadas em R-10 (iDCs), a transfecção das células foi realizada em meio RPMI-1640 e, após 24 da transfecção, (dia 5), meio RPMI-1640 suplementado com SFB foi acrescentado para volume final de $2 \mathrm{~mL}$ e porcentagem final de soro de $10 \%$. Em ambos os casos a ativação, quando realizada (TNF-a ou coquetel de ativação), ocorreu 24 horas após a transfecção e o silenciamento foi avaliado 24 horas após a ativação. A avaliação do silenciamento foi realizada por citometria de fluxo - FACSCalibur com o software CellQuest (BD Biosciences) ou FACSCanto II com o software FACSDiva (BD Biosciences). Os dados obtidos foram analisados com o software FlowJo 8.7 (Tree Stars Inc.). A avaliação do silenciamento também foi realizada, em alguns casos, por PCR em tempo real. As linha do tempo dos ensaios de transfecção de iDCs (Figura 1A) e monócitos (Figura 1B) podem ser observadas no esquema abaixo. 


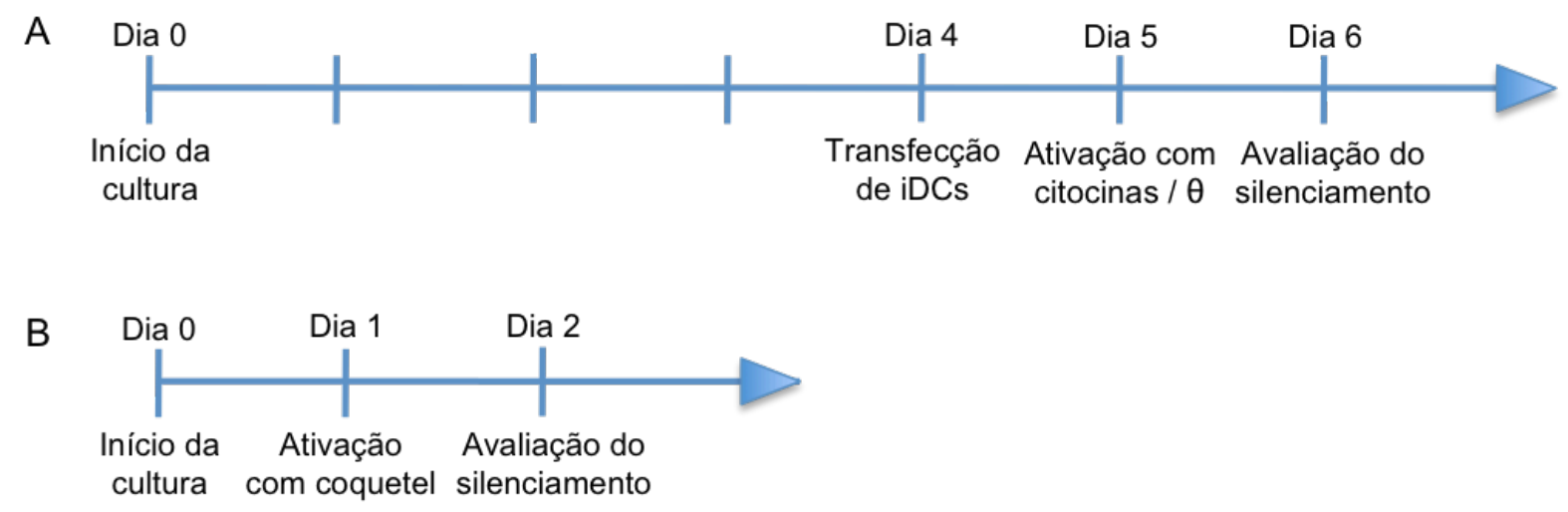

Figura 1 - Esquema indicativo da linha do tempo dos ensaios de transfecção de iDCs e monócitos. A: Células do quarto dia da cultura foram transfectadas, ativadas ou não $(\theta)$ após 24 horas da transfecção (dia 5) e, após 24 horas da ativação (dia 6), retiradas da cultura para a avaliação do silenciamento. B: Células $\mathrm{CD}_{14}{ }^{+}$foram separadas positivamente por beads magnéticas e imediatamente transfectadas (dia 0), ativadas com coquetel de ativação após 24 horas da transfecção (dia 1) e, após 24 horas da ativação (dia 2), retiradas da cultura para a avaliação do silenciamento.

\subsection{Extração de RNA total}

O RNA total de amostras de 5 a $10 \times 10^{6}$ células foi extraído com adição de 1 $\mathrm{mL}$ de Trizol $^{\circledR}$ (Invitrogen) e ressuspensão vigorosa com auxílio de pipeta. As amostras foram então incubadas por 5 minutos à temperatura ambiente para a completa dissociação dos complexos nucleoprotéicos. Adicionou-se $0,2 \mathrm{~mL}$ de clorofórmio e os tubos fechados contendo as amostras foram agitados manualmente de forma vigorosa por 15 segundos. Estas foram então incubadas de 2 a 3 minutos à temperatura ambiente. Após esse período, as amostras foram centrifugadas a 12000 g por 15 minutos a $4^{\circ} \mathrm{C}$. A fase aquosa incolor superior, contendo o RNA, foi retirada e transferida para outro tubo. O RNA foi então precipitado adicionando-se $0,5 \mathrm{~mL}$ de álcool isopropílico e incubado por 10 minutos à temperatura ambiente. Após a incubação, as amostras foram centrifugadas a $12000 \mathrm{~g}$ por 10 minutos a $4{ }^{\circ} \mathrm{C}$. O sobrenadante foi removido e o precipitado lavado com $1 \mathrm{~mL}$ de etanol $75 \%$ em água tratada com dietil dicarbonato (DEPC). Após leve agitação, as amostras foram centrifugadas a $7500 \mathrm{~g}$ por 5 minutos a $4{ }^{\circ} \mathrm{C}$, o sobrenadante removido e $\mathrm{O}$ precipitado seco à temperatura ambiente. Por fim, o RNA foi dissolvido em água DEPC para um volume de $15 \mu \mathrm{L}$ e armazenado a $-80^{\circ} \mathrm{C}$ para posterior quantificação pelo espectrofotômetro NanoDrop ND-1000 no comprimento de onda de $260 \mathrm{~nm}$ e avaliação da qualidade da extração $\left(\mathrm{A}_{260} / \mathrm{A}_{280}\right)$. A integridade do RNA extraído foi avaliada pela visualização de duas bandas fortes correspondentes aos RNAs das 
subunidades ribossomais $18 \mathrm{~S}$ e $28 \mathrm{~S}$, após eletroforese em gel de agarose 1,0\% corado com GelRed ${ }^{\mathrm{TM}}$ Nucleic Acid Gel Stain (Biotium) (Figura 2).

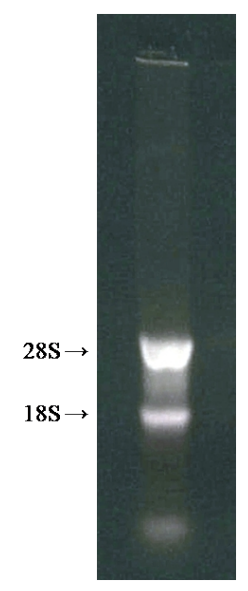

Figura 2 - Fotografia da eletroforese em gel de agarose do produto de extração de RNA total. Após extração do RNA total de células dendríticas maduras, o produto de extração submetido à eletroforese em gel de agarose $1,0 \%$, em que se observou o padrão de migração dos RNAs das subunidades ribossomais $18 \mathrm{~S}$ e $28 \mathrm{~S}$.

\subsection{Transcrição reversa, PCR e PCR em tempo real}

Para avaliação do silenciamento das moléculas CD80 e CD86 por transfecção das células com siRNAs específicos, assim como nos experimentos de determinação da cinética de expressão dessas moléculas durante uma cultura para diferenciação em células dendríticas (item 4.2), utilizou-se a técnica de reação em cadeia da polimerase (PCR) em tempo real com o kit SYBR ${ }^{\circledR}$ Green PCR Master Mix (Applied Biosystems). Para tanto, amostras de RNA foram submetidas à transcrição reversa (RT) para obtenção do DNA complementar (cDNA), que por sua vez foi amplificado por PCR em tempo real com a utilização de primers específicos. Assim, amostras de 3,0 $\mu \mathrm{g}$ de RNA total extraído íntegro foram diluídas para $11 \mu \mathrm{L}$ com água DEPC em microtubo livre de RNAse de 0,5 mL. A essas amostras adicionou-se $1 \mu \mathrm{L}$ de oligo(dT) ${ }_{18}$ primer $(0,5 \mu \mathrm{g} / \mu \mathrm{L})$. Este se hibridiza por complementaridade na cauda 3'poli(A) presente no RNA mensageiro maduro. As amostras foram então incubadas no termociclador a $70^{\circ} \mathrm{C}$ por 5 minutos, seguido de incubação a $25^{\circ} \mathrm{C}$ por 10 minutos, durante a qual adicionou-se por amostra um volume de $8 \mu \mathrm{L}$ contendo 4 $\mu \mathrm{L}$ de tampão da RT (5X) , $2 \mu \mathrm{L}$ de mix de desoxirribonucleotídeos trifosfatados (dNTPs) $(2,5 \mathrm{mM}), 1 \mu \mathrm{L}$ de ditiotreitol (DTT) $(0,1 \mathrm{M})$ e $1 \mu \mathrm{L}$ da enzima transcriptase

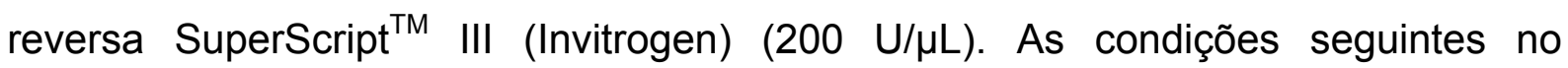


termociclador foram $42{ }^{\circ} \mathrm{C}$ por 1 hora e 15 minutos e $70{ }^{\circ} \mathrm{C}$ por 15 minutos. As amostras de cDNA assim obtidos foram então armazenadas a $-20^{\circ} \mathrm{C}$. Para garantir que houve a síntese correta do cDNA para a reação de PCR em tempo real, as amostras foram primeiramente amplificadas por uma reação de PCR tradicional em que se utilizaram primers para o gene GAPDH. A mistura da reação de PCR $(25 \mu \mathrm{L})$ consistiu de 2,5 $\mu \mathrm{L}$ do tampão (10X), 0,75 $\mu \mathrm{L}$ de $\mathrm{MgCl}_{2}$ (50 mM), 2,0 $\mu \mathrm{L}$ do mix de dNTPs $(2,5 \mathrm{mM}), 1,25 \mu \mathrm{L}$ de cada primer (10 pmol/ $\mu \mathrm{L}), 0,2 \mu \mathrm{L}$ da enzima Taq DNA Polimerase (Invitrogen) $(5 \mathrm{U} / \mu \mathrm{L})$ e $1 \mu \mathrm{L}$ do cDNA. As condições para a reação no termociclador consistiram de uma desnaturação inicial a $94{ }^{\circ} \mathrm{C}$ por 3 minutos, seguida de 35 ciclos de desnaturação a $94^{\circ} \mathrm{C}$ por 45 segundos, anelamento a $60^{\circ} \mathrm{C}$ por 30 segundos e extensão a $72{ }^{\circ} \mathrm{C}$ por 1 minuto e 30 segundos, com uma extensão final a $72{ }^{\circ} \mathrm{C}$ por 10 minutos. Após eletroforese em gel de agarose $1 \%$ corado com GelRed ${ }^{\mathrm{TM}}$ Nucleic Acid Gel Stain (Biotium) e visualização da banda única correspondente ao produto esperado, prosseguiu-se com a PCR em tempo real. Cada reação $(12,5 \mu \mathrm{L})$ foi composta por $6,25 \mu \mathrm{L}$ de SYBR, $4,25 \mu \mathrm{L}$ de água ultrapura autoclavada, $0,375 \mu \mathrm{L}$ de cada primer $(10 \mathrm{pmol} / \mu \mathrm{L})$ e $1 \mu \mathrm{L}$ de cDNA (previamente diluído a 1:10, no caso de CD80 e 1:100, no caso de CD86, CD83, HLA-DR e GAPDH, ou não diluídos, a depender do experimento). As condições para a reação foram: $95{ }^{\circ} \mathrm{C}$ por 10 minutos para a ativação da enzima AmpliTaq Gold DNA Polimerase presente no SYBR mix, 40 ciclos de desnaturação a $95^{\circ} \mathrm{C}$ por 15 segundos e anelamento e extensão a $60^{\circ} \mathrm{C}$ por 1 minuto, seguido da curva de dissociação $\left(95^{\circ} \mathrm{C}\right.$ por 1 minuto, $60^{\circ} \mathrm{C}$ por 30 segundos e $95^{\circ} \mathrm{C}$ por 30 segundos). A reação de PCR em tempo real foi realizada no equipamento Stratagene Mx3000P QPCR System e aquisição dos resultados pelo software $\mathrm{MxPro}^{\mathrm{TM}} 3.0$.

\subsubsection{Desenho dos primers}

Para avaliar a expressão dos genes CD80 e CD86 em estudo foram desenhados primers específicos para amplificação por PCR em tempo real. Pares de primers foram desenhados para avaliar a expressão dos genes constitutivos GAPDH e $\beta$-actina, necessários para a normalização dos resultados. Os primers para HLA-DR e CD40 foram também adquiridos para garantir que as seqüências de siRNAs não causarão nenhum efeito inespecífico, de modo que a expressão dessas moléculas também foi avaliada. Os primers foram desenhados com base nas 
seqüências de cDNAs presentes no banco de dados do NCBI (http://www.ncbi.nlm.nih.gov) com o auxílio do software PRIMER 3, e sintetizados pela Invitrogen Life Technologies. Restringiu-se o tamanho do produto amplificado a 100-200 pb, com anelamento de um dos primers entre a junção de dois éxons, para evitar a amplificação de produtos inespecíficos devido contaminação da amostra por DNA genômico. As seqüências dos primers e números de identificação das seqüências dos cDNA do banco de dados do NCBI estão descritos na Tabela 2.

Tabela 2 - Seqüências dos primers utilizados nas reações de PCR em tempo real. Seqüências dos primers foward $(F)$ e reverse $(R)$ para CD80, CD86, CD83, HLA-DR e GAPDH, e números de identificação das seqüências de cDNA presentes no banco de dados do NCBI utilizadas para o desenho desses.

\begin{tabular}{crc}
\hline Gene & \multicolumn{1}{c}{ Seqüências dos primers } & \#NCBI \\
\hline \multirow{2}{*}{ CD80 } & F5'-AGGGAACATCACCATCCAAG-3' & NM_005191 \\
& R5'-TGCCAGTAGATGCGAGTTTG-3' & \\
CD86 & F5'-TGTACGACGTTTCCATCAGC-3' & NM_006889 \\
& R5'-ATCCAAGGAATGTGGTCTGG-3' & NM_175862 \\
CD83 & F5'-CTTGCTCCGAAGATGTGGAC-3' & NM_004233.3 \\
& R5'-CTCTCTTCACCACCCTCCAA-3' & NM_001040280.1 \\
HLA-DR & F5'-GGTGGAGCACTGGGGCTTGG-3' & NM_019111.3 \\
& F5'-ACAGAGGCCCCCTGCGTTCT-3' & \\
GAPDH & F5'-AGGCTGGGGCTCATTTGCAGG-3' & NM_002046.3 \\
& R5'-TGACCTTGGCCAGGGGTGCT-3' & \\
\hline
\end{tabular}

3.6.2 Análise dos resultados de PCR em tempo real

O método matemático utilizado para quantificar a expressão dos mRNAs de interesse foi o método $\mathrm{Ct}$ (Threshold cicle) comparativo (LIVAK e SCHMITTGEN, 2001). Segundo o método Ct comparativo, subtrai-se o $\mathrm{Ct}$ da amostra de interesse pelo Ct do gene constitutivo dessa mesma amostra, no caso, GAPDH, dando origem ao valor $\Delta \mathrm{Ct}$. Em seguida, calcula-se o $\Delta \Delta \mathrm{Ct}$, que trata da diferença entre o valor de $\Delta$ Ct de uma amostra em questão e o $\Delta$ Ct de uma amostra calibradora, à qual todas as amostras farão referência. Neste projeto, utilizaram-se os valores de $\Delta \mathrm{Ct}$ do monócito, no caso do experimento de cinética de expressão dos mRNAs de CD80 e CD86 (item 4.2), e do grupo sem tratamento, no caso do experimento de avaliação 
de silenciamento (item 4.5.3) como amostras calibradoras. Por fim, calcula-se o valor de $2^{-\Delta \Delta C t}$, obtendo-se, assim, a expressão relativa de determinado gene de interesse. Este método parte do princípio de que a eficiência da reação de amplificação do gene alvo deve ser igual à do gene constitutivo, ambas próximas de $100 \%$. Testaram-se as eficiências de amplificação dos diferentes genes, e após constatação de eficiências acima de $90 \%$, foi possível eleger esse método de análise. Para a escolha do gene constitutivo, testaram-se os genes para a $\beta$-actina e GAPDH. Ambos variaram pouco entre as amostras, porém, pelo número grande de amostras e de genes analisados de uma vez por placa, apenas um deles pôde ser utilizado como gene constitutivo, tendo sido escolhido o GAPDH. As curvas de dissociação representativas de cada par de primers podem ser observadas na Figura 3).
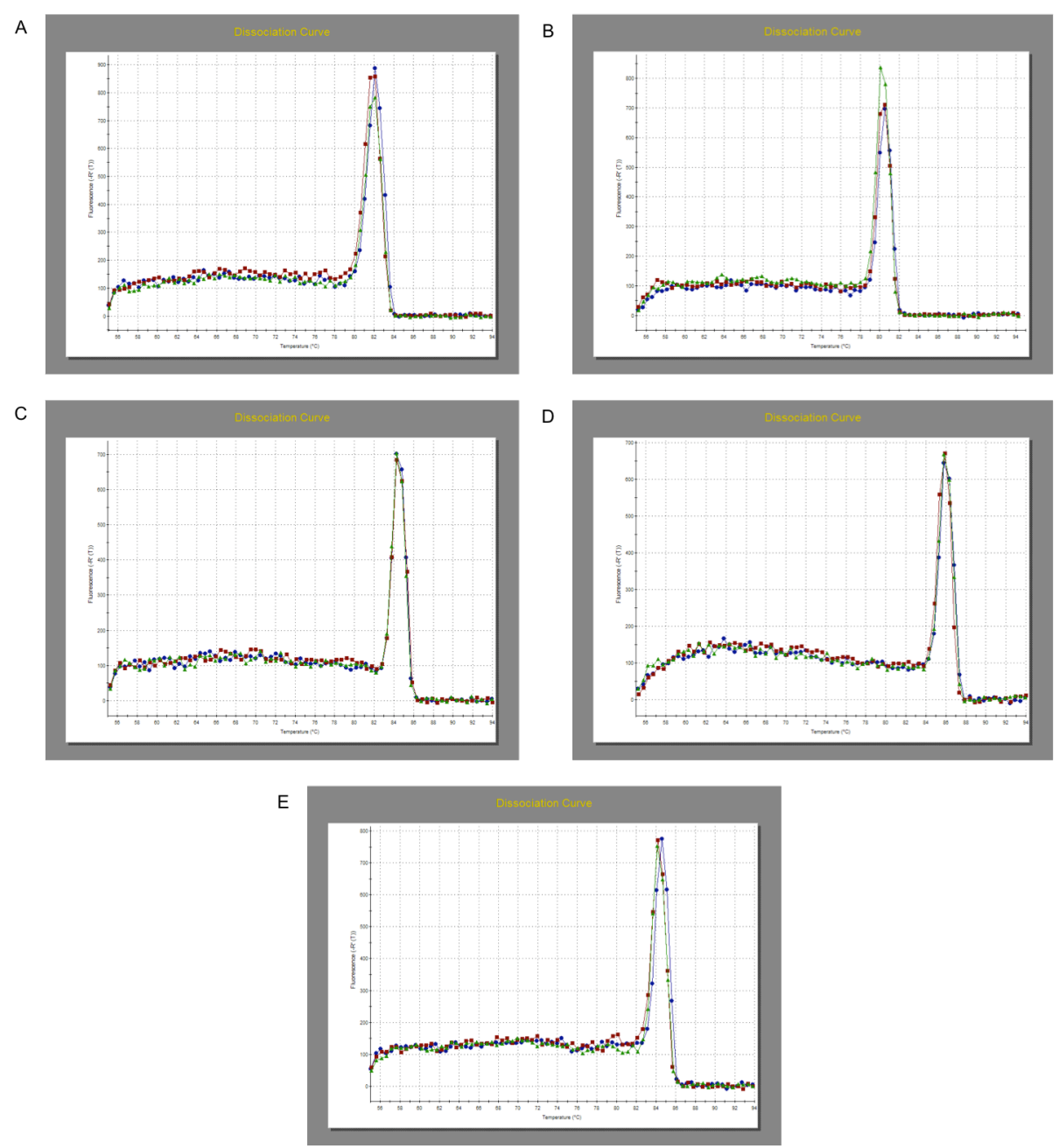

Figura 3 - Curvas de dissociação dos primers obtidas por PCR em tempo real. Curvas de dissociação representativas dos primers CD80 (A), CD86 (B), HLA-DR (C), CD83 (D) e GAPDH (E), obtidas por PCR em tempo real, a partir de RNA total extraído de células dendríticas. A presença de um pico único de dissociação corresponde à amplificação de um produto específico. 


\subsection{Análise fenotípica por citometria de fluxo}

Para determinação do fenótipo de membrana de monócitos, DCs imaturas (iDCs) e maduras (mDCs), essas células foram marcadas com anticorpos monoclonais comerciais para as seguintes moléculas de membrana: CD1a, CD11c, CD123, CD14, CD40, CD80, CD83, CD86 e HLA-DR (Tabela 3). Um conjunto de anticorpos para marcadores celulares de linfócitos T (CD3), B (CD19), monócitos e macrófagos (CD14) e células NK (CD56) foi utilizado, possibilitando a exclusão dessas células das análises fenotípicas das DCs. Este conjunto de marcadores de linhagem, identificado como Lineage (Lin), foi substituído em algumas análises pela utilização do anticorpo para a molécula CD14 apenas, após constatação de que linfócitos T, B e células NK são excluídos das análises pela delimitação de gate em tamanho e granulosidade característicos de DCs.

Após contagem, alíquotas de 1 a $2 \times 10^{5}$ células obtidas das culturas foram colocadas em tubos plásticos de $1,5 \mathrm{~mL}$ e lavadas três vezes por centrifugação a $13000 \mathrm{rpm}$ a $4{ }^{\circ} \mathrm{C}$ por 10 segundos com $200 \mu \mathrm{L}$ de tampão para citometria (PBS suplementado com $0,5 \%$ de soroalbumina bovina e $0,02 \%$ de azida sódica), obtendo-se um pellet, ao qual foram adicionados os anticorpos específicos para os marcadores de interesse. As células foram incubadas ao abrigo da luz por 20 minutos a $4^{\circ} \mathrm{C}$. Após esse período, adicionou-se $200 \mu \mathrm{L}$ de tampão para citometria e o material foi lavado mais uma vez nas mesmas condições e ressuspendido com $200 \mu \mathrm{L}$ de tampão para citometria contendo $2 \%$ de formaldeído para a fixação das células. Em seguida, as amostras foram adquiridas no citômetro de fluxo FACSCalibur com o software CellQuest (BD Biosciences) ou FACSCanto II com o software FACSDiva (BD Biosciences). Os dados obtidos foram analisados com 0 software FlowJo 8.7 (Tree Stars Inc.). 
Tabela 3 - Dados referentes aos anticorpos murinos usados para citometria de fluxo. Tabela de anticorpos monoclonais, indicando a especificidade do anticorpo (molécula), o clone, o isotipo e a cor, utilizados para citometria de fluxo de monócitos e células dendríticas. Todos os anticorpos foram adquiridos da BD Biosciencies.

\begin{tabular}{|c|c|c|c|}
\hline Molécula & Clone & Isotipo & Cor \\
\hline CD14 & M5E2 & $\operatorname{lgG} 2 a, \mathbf{k}$ & FITC \\
\hline CD14 & M5E2 & $\operatorname{lgG} 2 a, \mathbf{k}$ & PE \\
\hline CD19 & HIB19 & $\operatorname{lgG} 1, \mathbf{k}$ & FITC \\
\hline CD56 & NCAM16.2 & $\operatorname{lgG} 2 b, \mathbf{k}$ & FITC \\
\hline CD3 & HIT3a & $\operatorname{lgG} 2 a, \mathbf{k}$ & FITC \\
\hline HLA-DR & L243 (G46-6) & $\operatorname{lgG} 2 a, \mathbf{k}$ & $\mathrm{APC}$ \\
\hline CD11c & B-ly6 & $\operatorname{lgG} 1, \mathbf{k}$ & PE \\
\hline CD11c & B-ly6 & $\lg G 1, \mathbf{k}$ & PE-Cy5 \\
\hline CD1a & HHI149 & $\lg G 1, \mathbf{k}$ & PE \\
\hline CD123 & $9 F 5$ & $\lg G 1, \mathbf{k}$ & PE-Cy5 \\
\hline CD80 & L307.4 & $\lg G 1, \mathbf{k}$ & PE-Cy5 \\
\hline CD86 & 2331 (FUN-1) & $\lg G 1, \mathbf{k}$ & $P E$ \\
\hline CD40 & $5 \mathrm{C} 3$ & $\lg G 1, \mathbf{k}$ & PE \\
\hline CD40 & $5 \mathrm{C} 3$ & $\lg G 1, \mathbf{k}$ & PE-Cy5 \\
\hline CD83 & HB15e & $\lg G 1, \mathbf{k}$ & PE-Cy5 \\
\hline CD83 & HB15e & $\lg G 1, \mathbf{k}$ & $\mathrm{APC}$ \\
\hline
\end{tabular}

Para a análise fenotípica de monócitos, após as duas horas de aderência no dia zero da cultura e a retirada das células não-aderentes (CNAs), as células aderentes foram marcadas com anticorpos e fenotipadas. Em plot de tamanho (FSC - forward scatter) por granulosidade (SSC - side scatter), delimitou-se por um gate a população que possuía estes parâmetros característicos dos monócitos, e analisouse a população $C D 14^{+}$para a expressão das moléculas de interesse. No caso da fenotipagem de DCs imaturas (quinto dia) e maduras (sétimo dia), consideraram-se as células que, dentro do gate de tamanho e granulosidade característicos, eram HLA-DR ${ }^{+}$. O marcador de linhagem CD14 nesses casos funciona como controle de diferenciação e maturação celular. Gráficos pseudo-coloridos representativos das populações de monócitos, iDCs e mDCs, bem como o modo de análise fenotípica dessas populações, podem ser observados na Figura 4. 

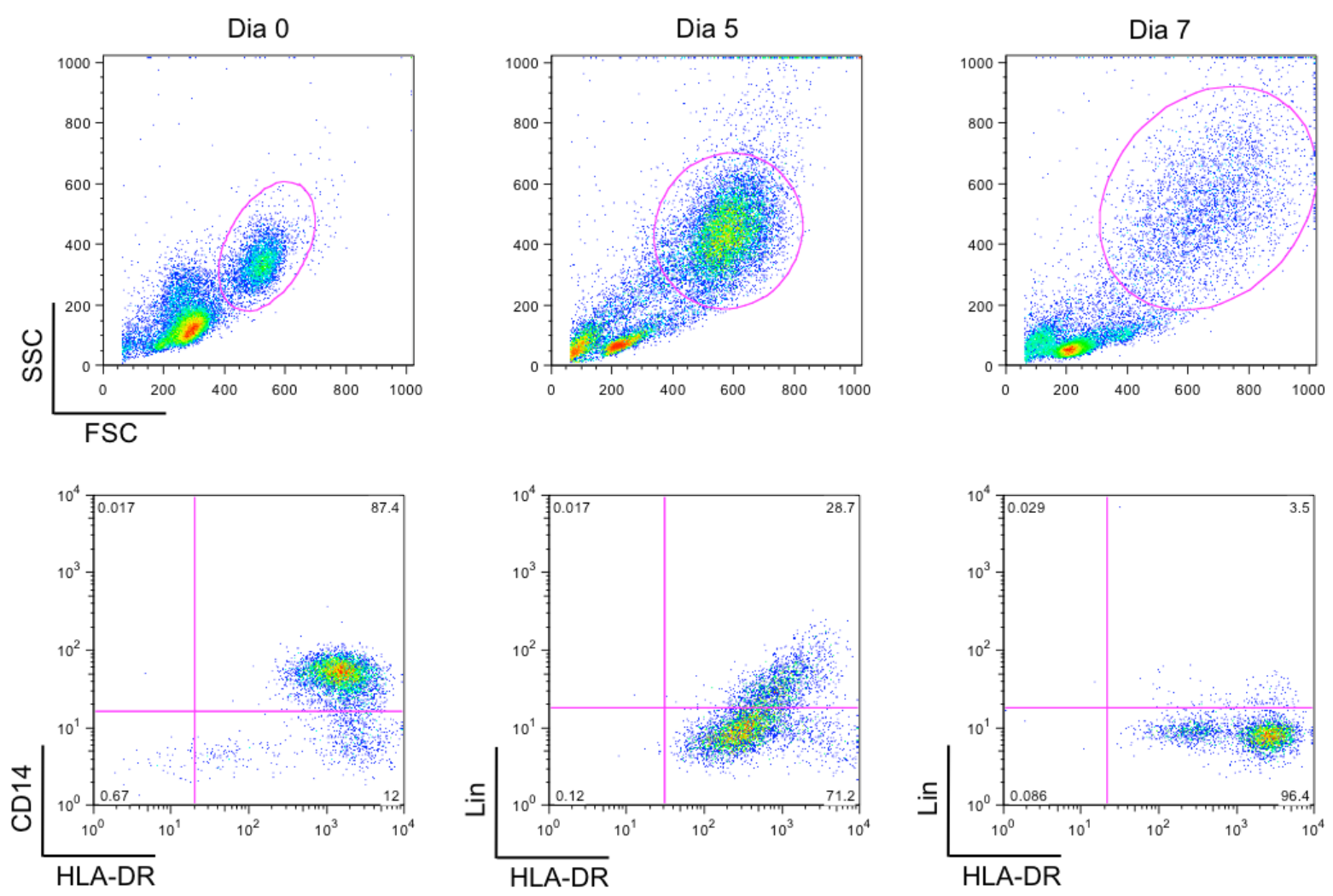

Figura 4 - Método de análise de monócitos, células dendríticas imaturas e maduras. Gráficos pseudo-coloridos indicando o modo de análise de monócitos, células dendríticas imaturas e maduras, retirados da cultura para diferenciação de células dendríticas nos dias zero, cinco e sete, respectivamente, para caracterização fenotípica por citometria de fluxo. Topo: Gráficos pseudo-coloridos de tamanho (FSC) por granulosidade (SSC), em que se delimitou um gate para seleção da população com tamanho e granulosidade característicos das células em análise. Base: Gráficos pseudo-coloridos de CD14 ou lineage (CD3, CD19, CD56 e CD14) por HLA-DR dentro dos gates de tamanho e granulosidade característicos das células em análise, em que se delimitou, no caso de monócitos, gate para as células CD14 ${ }^{+} \mathrm{HLA}_{-}-\mathrm{RR}^{+}$e, no caso de iDCs e mDCs, gate para as células HLA-DR ${ }^{+}$, nos quais as análises fenotípicas foram realizadas.

\subsection{Imunofluorescência}

Para a visualização da transfecção celular, realizou-se também a técnica de imunoflorescência. Para tanto, células do quarto dia da cultura para diferenciação em células dendríticas foram retiradas e plaqueadas sobre lamínulas previamente dispostas em poços da placa de cultura de 6 poços, de acordo com o protocolo descrito em 3.4. Após 24 horas de transfecção, os poços foram lavados cuidadosamente com $1 \mathrm{~mL}$ de PBS $2 \mathrm{X}$, seguido por fixação das células com paraformaldeído $4 \%$ em água por 10 minutos a $4{ }^{\circ} \mathrm{C}$. Após a fixação, os poços foram lavados duas vezes com PBS, e $300 \mu \mathrm{L}$ de 4',6-diamidino-2-fenilindol (DAPI) (10 $\mu \mathrm{g} / \mathrm{mL}$ ) foram adicionados para incubação por 30 minutos à temperatura ambiente. 
Por fim, realizou-se mais uma lavagem com PBS, e as lamínulas retiradas foram montadas com glicerol-PBS 1:1 em lâminas para microscopia, e seladas com esmalte. Estas foram guardadas ao abrigo da luz a $4{ }^{\circ} \mathrm{C}$ para leitura em microscópio de fluorescência no mesmo dia. As fotos retiradas foram deconvoluídas pelo software Huygens Deconvolution para remoção dos "ruídos" e marcações inespecíficas, e coloridas pelo software ImageJ $1.43 r$.

\subsection{Avaliação da viabilidade celular}

\subsubsection{Por exclusão do Azul de Tripan}

A viabilidade celular dos diferentes grupos foi avaliada 48 horas após a transfecção pela capacidade de exclusão do Azul de Tripan 0,4\% (Sigma). Uma alíquota de $10 \mu \mathrm{L}$ de células foi misturada a uma alíquota de mesmo volume do corante Azul de Tripan. Contou-se em um quadrante o número de células vivas e mortas, estabelecendo-se assim a porcentagem de células vivas em relação ao total de células contadas.

\subsubsection{Por marcação com anexina e iodeto de propídeo (PI)}

A viabilidade celular também foi avaliada por marcação das células com anexina-V (Proteimax) e iodeto de propídeo (PI) (BD Pharmingen). Células apoptóticas expõem resíduos de fosfatidilserina no folheto externo da membrana celular, os quais se ligam à anexina. Já o PI é um corante que penetra células mortas e se liga ao DNA. Morte por apoptose tardia é identificada por células anexina ${ }^{+} \mathrm{PI}^{+}$, necrose por células anexina- $\mathrm{PI}^{+}$e apoptose inicial por células anexina ${ }^{+} \mathrm{PI}^{-}$. Após 48 horas da transfecção, as células foram removidas da placa, aliquotadas em tubos plásticos de $1,5 \mathrm{~mL}$, lavadas com $200 \mu \mathrm{L}$ tampão de ligação diluído 1X (BD Pharmingen) e ressuspendidas em um mix contendo anexina (1 $\mathrm{\mu g} /$ $\mu \mathrm{L})$ na diluição final 1:500 e $5 \mu \mathrm{L}$ de PI $(50 \mu \mathrm{g} / \mathrm{mL})$ para um volume final de $100 \mu \mathrm{L}$ de tampão de ligação. As amostras foram incubadas por 20 minutos à temperatura ambiente no escuro. Após esse período, adicionou-se mais $100 \mu \mathrm{L}$ de tampão de ligação em cada amostra e estas foram lidas imediatamente no citômetro de fluxo FACSCanto II com o software FACSDiva (BD Biosciences). Os dados obtidos foram 
analisados com o software FlowJo 8.7 (Tree Stars Inc.). A calibração do citômetro foi efetuda com base em células mortas, as quais foram expostas a $65^{\circ} \mathrm{C}$ por 15 minutos e marcadas com anexina e/ou $\mathrm{PI}$. Os gráficos pseudocoloridos desse controle podem ser observados na Figura 5.

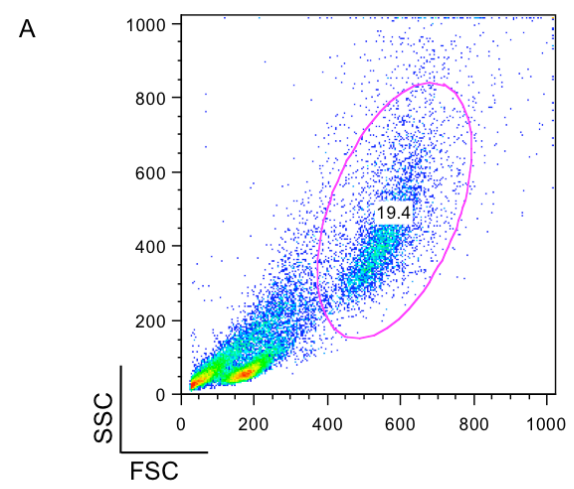

B

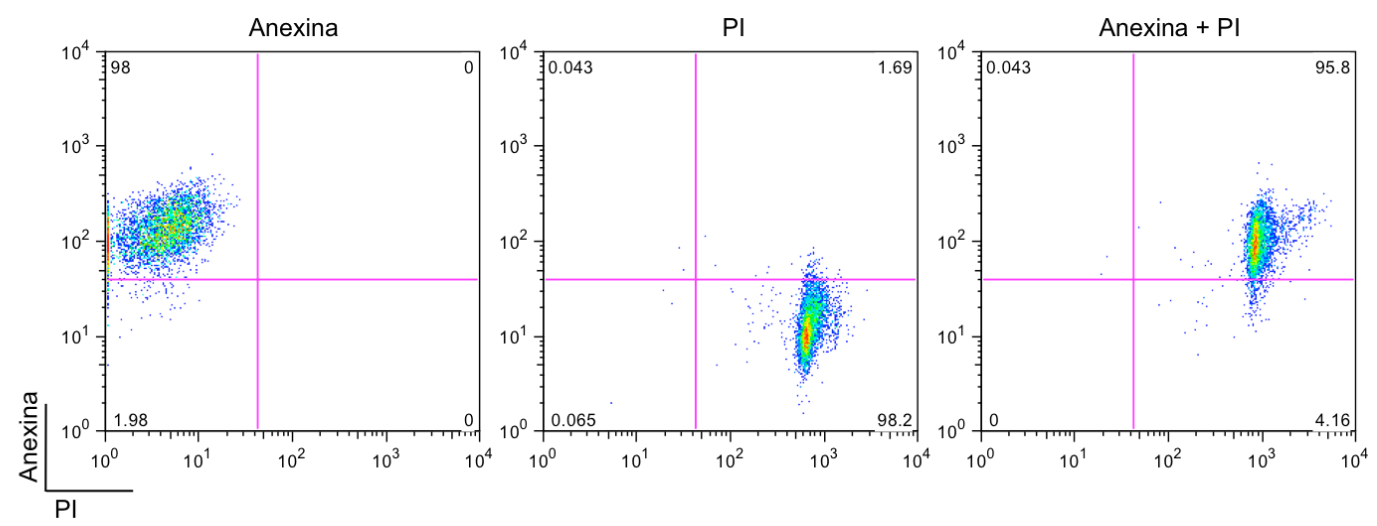

Figura 5 - Gráficos pseudocoloridos do controle de células mortas marcadas com anexina e/ou PI. Gráficos pseudo-coloridos indicando o controle de células mortas por exposição a 65 ${ }^{\circ} \mathrm{C}$ por 15 minutos e marcadas com anexina e/ou PI.

\subsection{Seleção positiva de células CD14+ por beads magnéticas}

Após a separação de células mononucleares por gradiente de Ficoll e lavagens, de acordo com protocolo descrito em 3.2, $2 \times 10^{8}$ células foram lavadas em $1,6 \mathrm{~mL}$ de PBS-BSA-EDTA $(0,5 \%$ de BSA e $3 \mathrm{mM}$ de EDTA), e então ressuspendidas em $1,6 \mathrm{~mL}$ do mesmo tampão contendo $400 \mu \mathrm{L}$ de suspensão de beads magnéticas anti-CD14 (Miltenyi Biotec). Após incubação por 30 minutos a 4 ${ }^{\circ} \mathrm{C}$, adicionou-se $4 \mathrm{~mL}$ de tampão PBS-BSA-EDTA e as células foram centrifugadas a $300 \mathrm{~g}$ por 10 minutos, e ressuspendidas em $1 \mathrm{~mL}$ para posterior seleção positiva por MACS®-sorting utilizando coluna LS (Miltenyi Biotec). A coluna foi então lavada três vezes com $3 \mathrm{~mL}$ do tampão para remoção das células não ligadas, removida do 
equipamento e lavada mais duas vezes com $5 \mathrm{~mL}$ do tampão PBS-BSA-EDTA para captação das células $\mathrm{CD}_{14}^{+}$. Tanto as células $\mathrm{CD}^{+} 4^{+}$como as $\mathrm{CD}^{-} 4^{-}$foram marcadas com anticorpos anti-CD14 e anti-CD3 para determinação de pureza, que atingiu 95\% (Figura 6). As células CD14+ foram imediatamente utilizadas em ensaios de transfecção com siRNAs de acordo com protocolo descrito em 3.4.
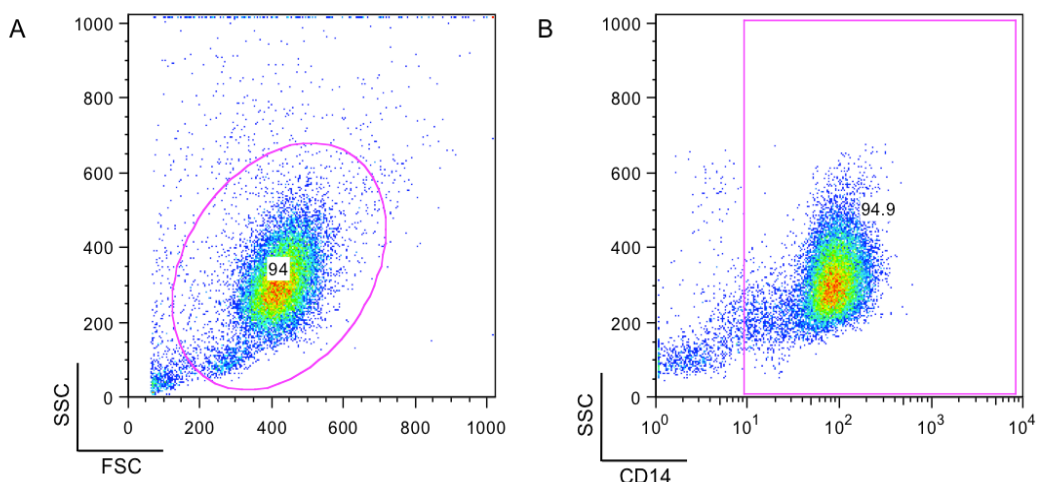

Figura 6 - Gráficos pseudo-coloridos indicando a pureza das células $C^{2} 14^{+}$após seleção positiva com beads magnéticas. A: Gráfico pseudo-colorido de tamanho (FSC) por granulosidade (SSC) indicando o gate de análise da população de células CD14 ${ }^{+}$após seleção positiva de células mononucleares do sangue periférico por beads magnéticas. B: Gráfico pseudo-colorido de granulosidade (SSC) por CD14 indicando a porcentagem de células $\mathrm{CD} 14^{+}$após seleção positiva com beads magnéticas.

\subsection{Análise estatística}

Os dados obtidos quanto à fenotipagem de monócitos, iDCs e mDCs foram, inicialmente, analisados quanto à homogeneidade da variância, utilizando-se o Teste de Bartlett. Após este teste, as amostras foram avaliadas pelo teste de análise da variância (ANOVA), seguida pelo teste de comparações múltiplas de Tukey-Kramer, neste caso os gráficos apresentam as médias dos grupos. No caso de uma distribuição não-Gaussiana, foi utilizado para análise o teste não-paramétrico de Kruskal-Wallis, seguido pelo teste de comparações múltiplas de Dunn (gráficos apresentando a mediana dos grupos). As eficiências da transfecção de células com os agentes de transfecção siPORT e iMAX foram comparadas pelo teste $\mathrm{T}$ de Student. A avaliação da viabilidade celular por exclusão do corante Azul de Tripan após tratamentos com os agentes de transfecção, e a avaliação do silenciamento de CD80 e CD86 em DCs após 48 da transfecção com siRNAs e siPORT, foram analisadas pelo teste ANOVA, seguido pelo teste de comparações múltiplas de 
Tukey-Kramer, sendo indicadas as médias e os desvios padrões em cada caso. Em todas as análises, considerou-se significante o valor de $p<0,05$. 
4 RESULTADOS 


\subsection{Caracterização fenotípica de monócitos, DCs imaturas e maduras}

As células dendríticas foram originadas a partir de monócitos de sangue periférico de doadores saudáveis, e tratados com GM-CSF e IL-4 por cinco dias para diferenciação em células dendríticas imaturas. No quinto dia da cultura adicionou-se TNF- $\alpha$ para a ativação das células, obtendo-se ao sétimo dia da cultura células dendríticas maduras. Monócitos, DCs imaturas e maduras (culturas dias zero, cinco e sete, respectivamente), foram avaliadas quanto à positividade e à expressão das moléculas de superfície CD14, HLA-DR, CD11c, CD1a, CD123, CD80, CD86, CD40 e CD83. O aspecto morfológico representativo das células de uma cultura realizada em meio AIM-V está representado nas fotos da Figura 8A. É possível observar-se aumento de tamanho das células com os estímulos de diferenciação e ativação, bem como maior número de células arredondadas, com prolongamentos de membrana visíveis ao micrométrico, no sétimo dia da cultura em comparação às do quinto dia. Os histogramas representativos da expressão das moléculas CD14, HLA-DR e CD80 em Mo, iDCs e mDCs ao longo do processo de diferenciação e ativação estão representados nas Figuras $7 \mathrm{~B}, \mathrm{C}$ e $\mathrm{D}$, respectivamente. 


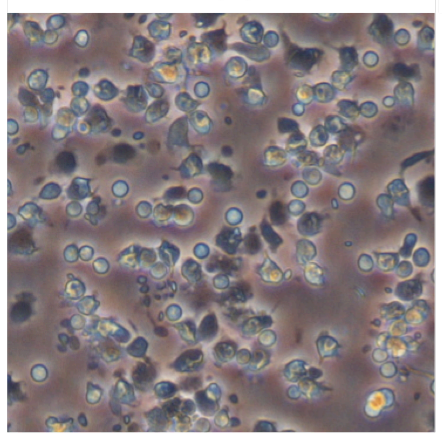

Dia 5

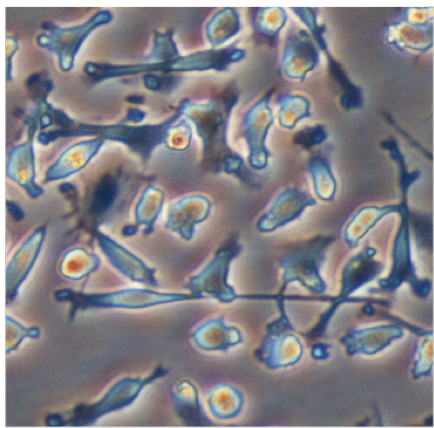

Dia 7

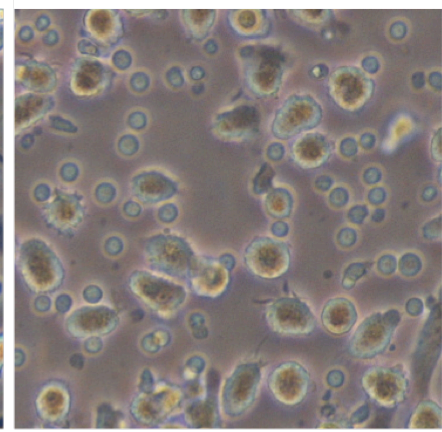

B

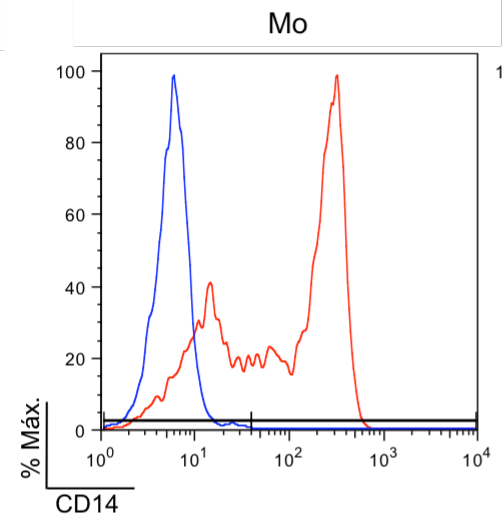

C

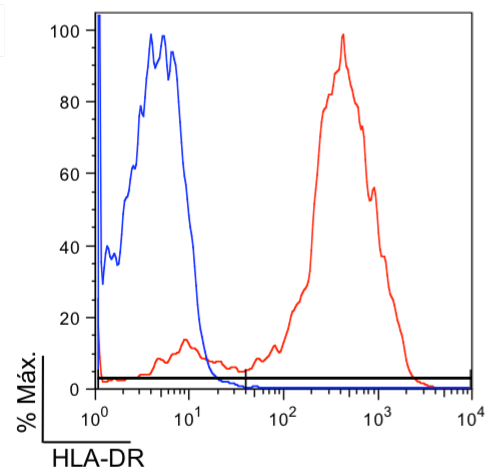

D

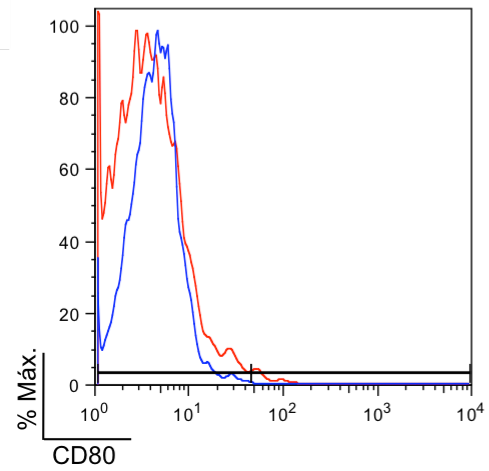

iDC
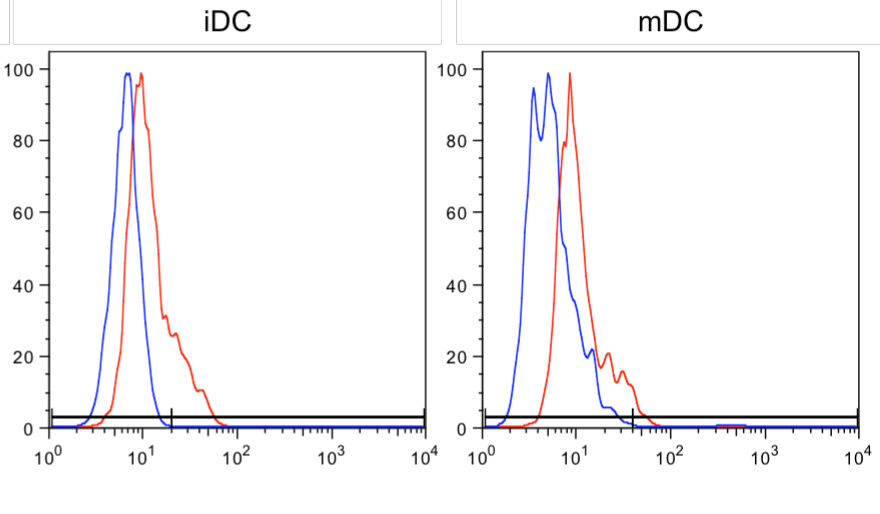
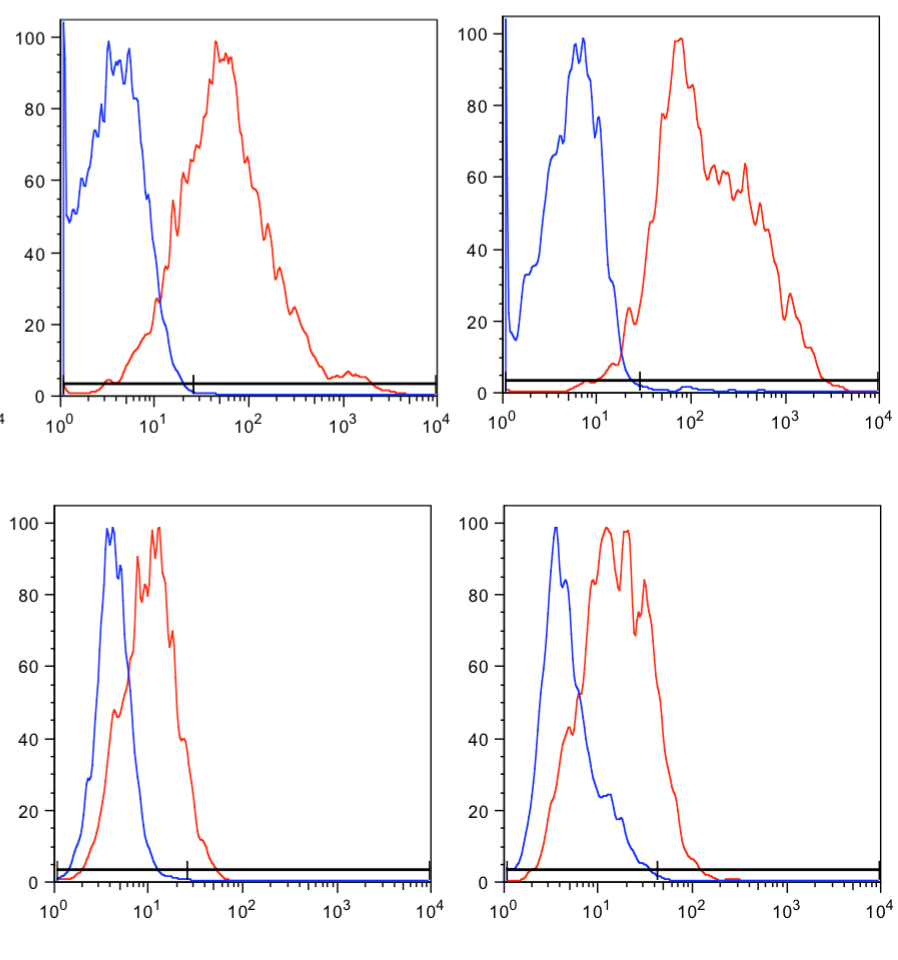

Figura 7 - Fotomicrografias de uma cultura nos dias zero, cinco e sete e histogramas de CD14, HLA-DR e CD80 de monócitos (Mo), células dendríticas imaturas (iDCs) e maduras (mDCs). A: Fotomicrografias representativas de uma cultura para diferenciação em células dendríticas, realizada no meio de cultura AIM-V e estímulo de ativação por TNF- $\alpha$, nos dias zero, cinco e sete. Fotomicrografias retiradas em contraste de fase e aumento de 200X. BD: Histogramas das intensidades medianas de fluorescência das moléculas de membrana CD14 (B), HLA-DR (C) e CD80 (D) de Mo, iDCs e mDCs (linhas vermelhas), em comparação com células não marcadas (linhas azuis), a partir de cultura para diferenciação em DCs realizada em meio AIM-V e estímulo de ativação por TNF- $\alpha$. 
$\mathrm{Na}$ figura 8 são apresentados gráficos de dispersão com as médias ou medianas das freqüências das células positivas para as diferentes moléculas na superfície de Mo, iDCs e mDCs, nas culturas realizadas em meio AIM-V. Observouse que, durante a diferenciação das células dendríticas a partir de monócitos, houve diminuição significativa na freqüência de células $\mathrm{CD} 14^{+}$, marcadora de monócitos e macrófagos, tanto entre monócitos e iDCs quanto entre monócitos e mDCs $(p<$ 0,001). Entre monócitos e iDCs, houve aumento significativo da freqüência de células com expressão de $\operatorname{CD1a}(p<0,01)$, diminuição significativa de células $\operatorname{CD}^{+} 6^{+}$ $(p<0,05)$, e aumento significativo de células $\operatorname{CD} 40^{+}(p<0,05)$. Não houve diferenças significativas para as moléculas CD11c, HLA-DR, CD123, CD80 e CD83. Já entre iDCs e mDCs as variações observadas, embora consistentes com o esperado, como diminuição da freqüência de células $\mathrm{CD}_{1} \mathrm{a}^{+}$e aumento da freqüência de células $C D 86^{+}$, não atingiram significância estatística. 
CD14

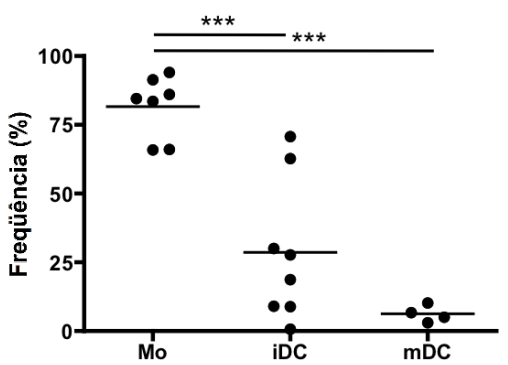

CD1a

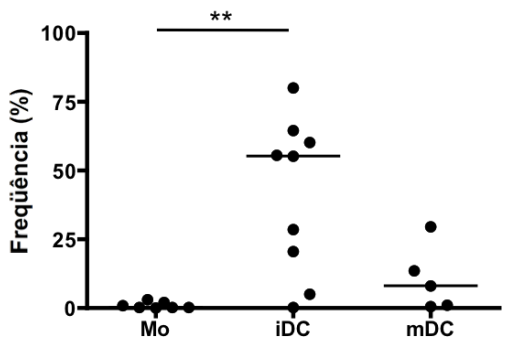

CD86

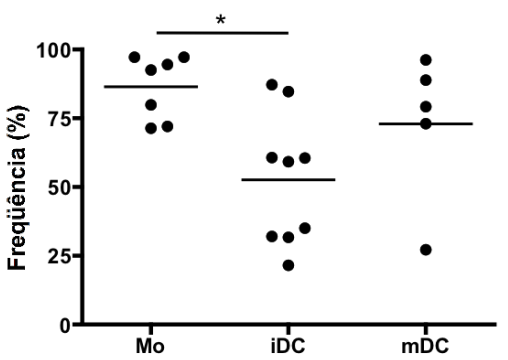

CD11c

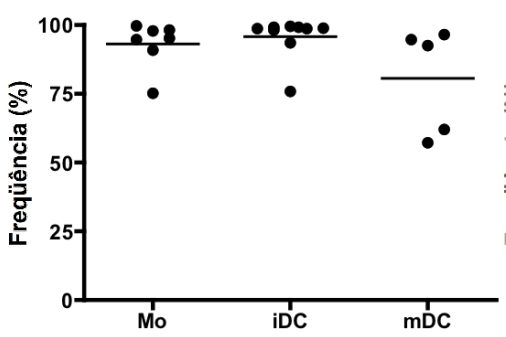

CD123

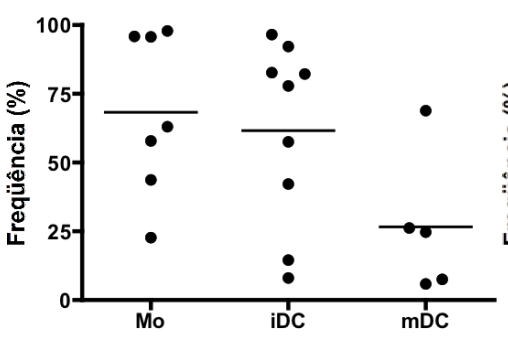

CD40

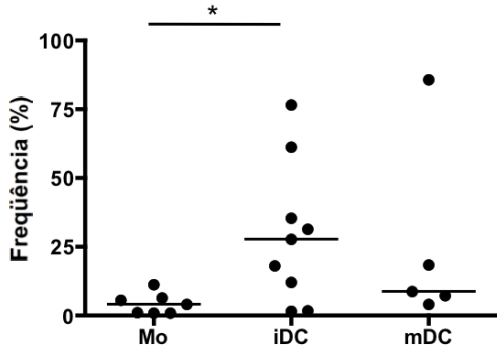

HLA-DR

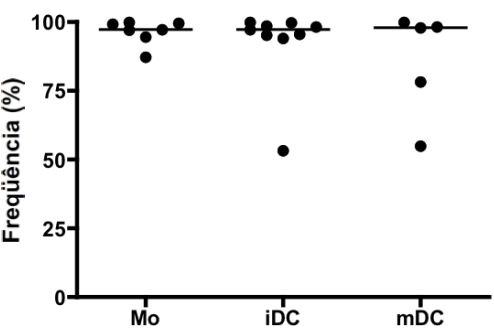

CD80

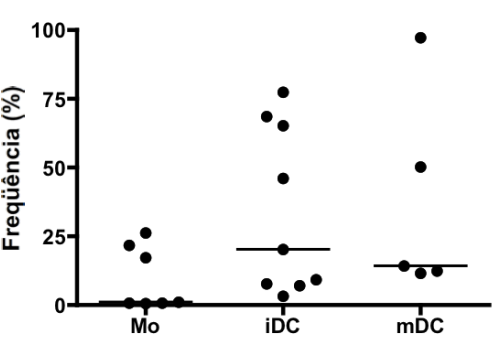

CD83

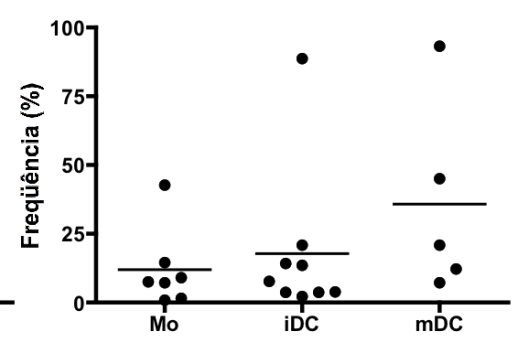

Figura 8 - Fenótipo de monócitos, células dendríticas imaturas e maduras. Gráficos de dispersão indicativos das médias ou medianas das porcentagens de células positivas para as moléculas de superfície CD14, HLA-DR, CD11c, CD1a, CD123, CD80, CD86, CD40 e CD83 em monócitos (Mo), DCs imaturas (iDC) e maduras ( $\mathrm{mDC}$ ), a partir de culturas para diferenciação em DCs realizadas em meio AIM-V e estímulo de ativação com TNF- $\alpha$. Análises estatísticas realizadas pelo teste ANOVA seguido pelo teste de comparações múltiplas de Tukey-Kramer, ou Kruskal-Wallis, seguido pelo teste de comparações múltiplas de Dunn; * $p<0,05 ;{ }^{* *} p<0,01 ;{ }^{* * *} p<0,001$.

Com relação às intensidades medianas de fluorescência (MFI) das células positivas para a expressão dessas moléculas (Figura 9), observou-se diminuição significativa da MFI de CD14 tanto entre monócitos e iDCs quanto entre monócitos e mDCs $(p<0,05)$. Também observou-se aumento significativo da MFI de CD86 com o estímulo de ativação das DCs $(p<0,01)$. As demais variações não foram significativas. 


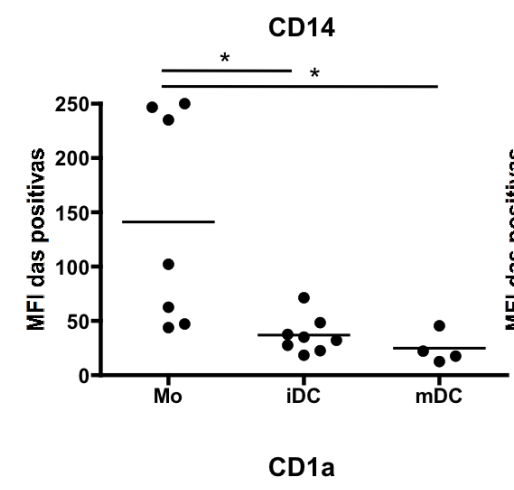

CD11c

HLA-DR
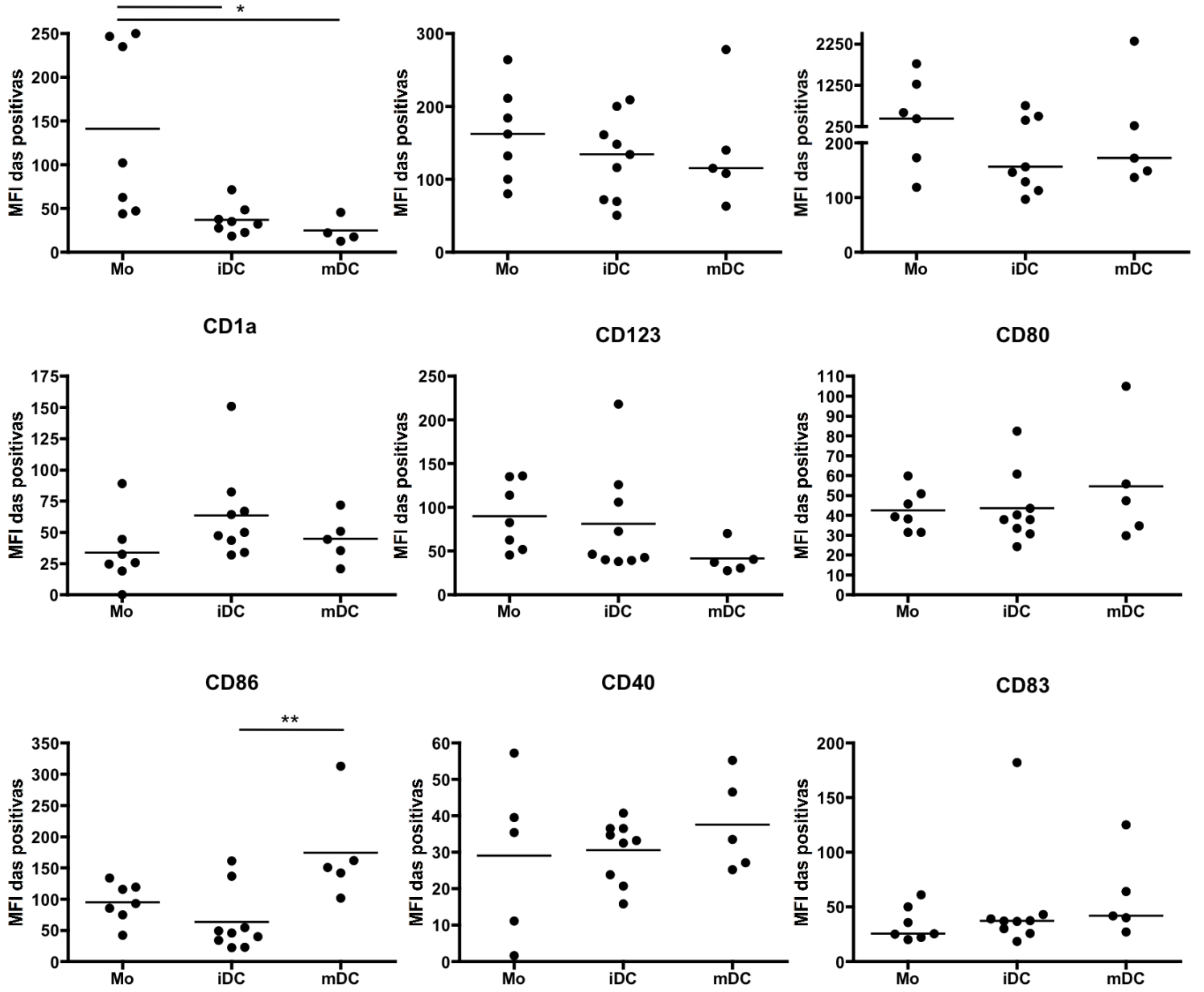

Figura 9 - Intensidade mediana de fluorescência (MFI) de monócitos, células dendríticas imaturas e maduras. Gráficos de dispersão indicativos das médias ou medianas das MFIs para as moléculas de superfície CD14, HLA-DR, CD11c, CD1a, CD123, CD80, CD86, CD40 e CD83 em monócitos (Mo), DCs imaturas (iDC) e maduras (mDC), a partir de culturas para diferenciação em DCs realizadas em meio AIM-V e estímulo de ativação com TNF- $\alpha$. Análises estatísticas realizadas pelo teste ANOVA seguido pelo teste de comparações múltiplas de Tukey-Kramer, ou Kruskal-Wallis, seguido pelo teste de comparações múltiplas de Dunn; * $p<0,05 ;{ }^{* *} p<0,01$.

\subsection{Cinética de expressão de mRNA das moléculas CD80 e CD86}

Para detectar o momento ideal para a transfecção das células com siRNAs específicos, avaliou-se a cinética de expressão de mRNA de CD80 e CD86 por PCR em tempo real durante diferentes momentos da cultura para diferenciação em DCs: 2 e 24 horas após a adição de GM-CSF e IL-4, no quinto dia da cultura (iDC) e 2, 4, 6, 8, 24 e 48 horas após a adição de TNF-a. Os resultados de expressão relativa das moléculas em dois experimentos independentes podem ser observados na Figura $10 \mathrm{~A}$. 
A

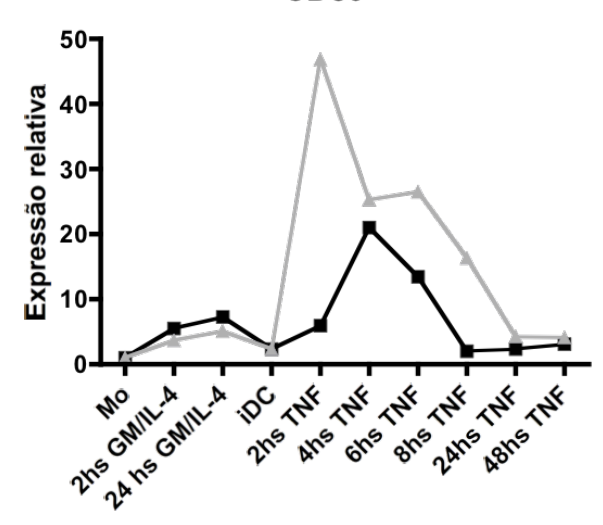

B

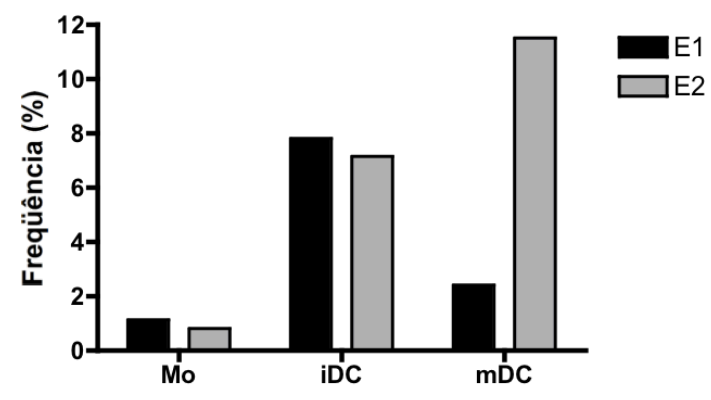

C

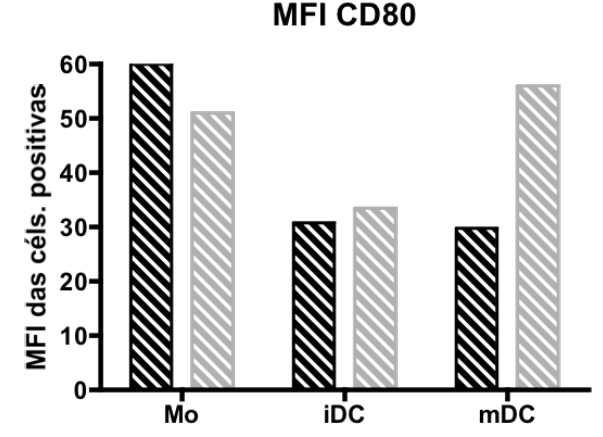

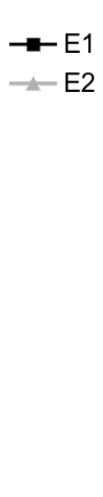

$-E 1$

E2

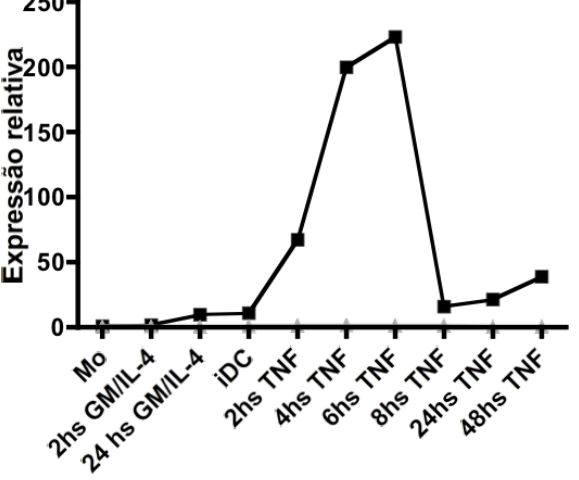

CD86

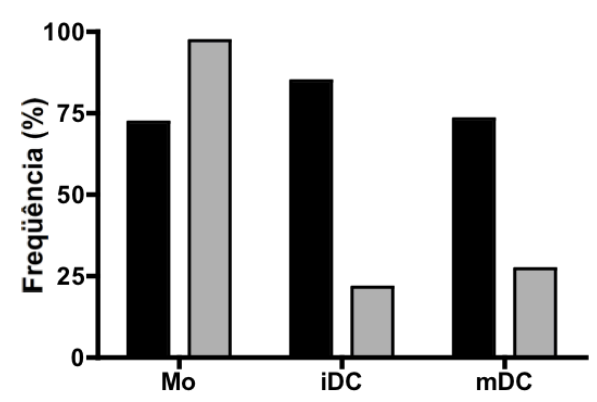

MFI CD86

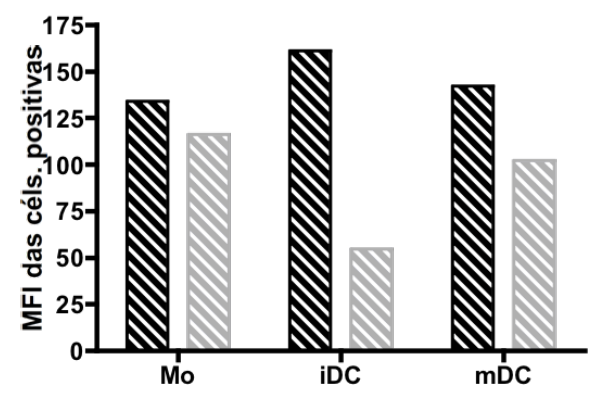

IIV1

NIVE2

$\rightarrow-E 1$

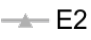

MIN1

NIVE2

Figura 10 - Cinética da expressão dos mRNAs de CD80 e CD86 e correlação com expressão na superfície. A: Expressão relativa das moléculas CD80 e CD86 em diferentes momentos da cultura para diferenciação em células dendríticas (2 e 24 horas após a adição de GMCSF e IL-4, no quinto dia da cultura (iDC) e 2, 4, 6, 8, 24 e 48 horas após a adição de TNF- $\alpha$ ), em dois experimentos independentes, E1 e E2. B e C: Gráficos indicativos das freqüências $(B)$ e intensidades medianas de fluorescência das células positivas (MFI das positivas) (C) para as moléculas CD80 e CD86, retiradas da cultura para diferenciação em células dendríticas nos dias zero (Mo), cinco (iDC) e sete (mDC), em dois experimentos independentes, E1 e E2. 
Em ambos os experimentos observou-se aumento de expressão do mRNA de CD80 para cerca de 7,5 vezes em relação ao monócito, após 24 horas da adição de GM-CSF e IL-4. Essa expressão volta a quase sua expressão basal no quinto dia da cultura, em que as células dendríticas já se encontram diferenciadas e em estado imaturo, e volta a subir após a adição do estímulo de maturação TNF- $\alpha$. A expressão chegou em seu ponto máximo após 4 horas da ativação das células no experimento 1, e após 2 horas no experimento 2, atingindo 21 vezes e 47 vezes a expressão do monócito, respectivamente. A expressão voltou para nível quase basal após 8 horas da ativação no experimento 1, enquanto no experimento 2 essa queda só foi observada após 24 horas da ativação.

Já a expressão relativa de CD86 variou apenas no experimento 1. A expressão se manteve basal nos momentos observados até o estímulo com TNF- $\alpha$, que causou aumento de expressão de mRNA com pico após 6 horas da ativação, de quase 223 vezes à expressão do monócito. Houve diminuição de expressão após 8 horas desse mesmo estímulo, mas se manteve elevada mesmo após 48 horas da ativação, com cerca de 39 vezes a expressão do monócito.

Na tentativa de correlacionar a expressão do mRNA de CD80 e CD86 com a expressão das moléculas correspondentes na superfície das células, estas foram marcadas com anticorpos nos dias zero (monócito), cinco (iDC) e sete (mDC) da cultura, lidas no citômetro de fluxo e analisadas de acordo com a freqüência, e com a intensidade mediana de fluorescência das células positivas. Com relação à pocentagem de células positivas para esses marcadores (Figura 10B), no experimento 1, apesar do grande aumento da expressão do mRNA para CD86 após a ativação das células, observou-se leve diminuição da freqüência das células positivas para esse marcador, já que esta foi de $84,8 \%$ no quinto dia da cultura para $73 \%$ no sétimo. Em contrapartida, a produção basal de mRNA para CD86 observada ao longo de toda a cultura no experimento 2 não foi capaz de manter a expressão elevada da molécula na superfície, cuja freqüência de células positivas foi de $97 \%$ no dia zero da cultura para $21,5 \%$ no quinto dia, com leve aumento para $27 \%$ no sétimo. Observando-se a expressão da molécula CD80 na superfície, pode-se dizer que em ambos os experimentos houve aumento da freqüência de células positivas do dia zero da cultura para o quinto dia, indo de quase zero para $7,8 \%$ e $7,1 \%$ nos experimentos 1 e 2, respectivamente, em concordância com o aumento da expressão do mRNA para CD80 após a adição de GM-CSF e IL-4. Porém, enquanto 
no experimento 1 a expressão de CD80 na membrana celular diminuiu no sétimo dia da cultura para $2,4 \%$ das células, ela aumentou para $11,5 \%$ no experimento 2 , apesar de em ambos os experimentos ter sido observado aumento de expressão do mRNA com adição de TNF- $\alpha$, embora esse aumento de expressão tenha sido 47 vezes a do monócito no experimento 2 , e apenas 21 vezes no 1.

Com relação à expressão das moléculas CD80 e CD86 nas células positivas para esses marcadores (Figura 11C), pode-se dizer que, desconsiderando a expressão de CD80 nos monócitos, uma vez que se trata de uma população de muito poucas células, motivo pelo qual se observou alta MFI, de maneira geral, a expressão dessas moléculas nas populações obedeceu à mesma cinética da freqüência de células positivas.

Assim, embora os experimentos de cinética de expressão do mRNA tenham se mostrado coerentes, pelo menos no que diz respeito à molécula CD80, não é possível tirar-se conclusões seguras sobre a correlação da expressão dos mRNAs e a expressão das moléculas na superfície, de modo que, para que se possa compreender o mecanismo biológico de expressão dessas moléculas, é necessária a realização de um número maior de experimentos. Pode-se dizer, porém, que de maneira geral, a ativação das células com TNF- $\alpha$ desencadeia, poucas horas após o estímulo, um aumento da produção de mRNAs para CD80 e CD86. No contexto de transfecção das células para silenciamento das moléculas, optou-se, portanto, por realizar a transfecção 24 horas antes da ativação das células, portanto, no quarto dia da cultura.

\subsection{Padronização da transfecção de iDCs com siRNA marcado}

Para avaliar a transfecção de DCs utilizou-se um siRNA com especificidade ao mRNA de GAPDH, conjugado ao fluorocromo Cy3 (GAPDH-Cy3), o qual é detectado pelo canal FL2 do citômetro de fluxo. Testaram-se duas quantidades do agente de transfecção siPORT (3 e $5 \mu \mathrm{L}$ ) e três concentrações do siRNA controle (10, 30 e $50 \mathrm{nM})$. Vinte e quatro horas após a transfecção, as células foram retiradas da placa e lidas no citômetro de fluxo. Embora as células almejadas para a transfecção com siRNA sejam as do quarto dia da cultura, de acordo com o resultado obtido no experimento de cinética de expressão de mRNA (item 4.2), o experimento ora descrito foi realizado com células do sexto dia da cultura não 
ativadas com TNF- $\alpha$. Assim, células da garrafa de cultura foram retiradas com repetidas lavagens usando RPMI gelado e auxílio de cell scraper, contadas, e plaqueadas (1) sobre poços da placa de cultura contendo apenas $200 \mu \mathrm{L}$ de OptiMEM $^{\circledR}$ I (grupo sem tratamento), (2) sobre os complexos de transfecção contendo apenas o agente de transfecção siPORT (grupos siPORT) ou (3) sobre os complexos de transfecção contendo tanto o agente de transfecção siPORT como o siRNA (grupos siRNA).

Na Figura 11A é possível observar o gráfico pseudo-colorido de tamanho por granulosidade do grupo sem tratamento, e gráficos representativos dos grupos tratados com 3 e $5 \mu \mathrm{L}$ do agente de transfecção.

A

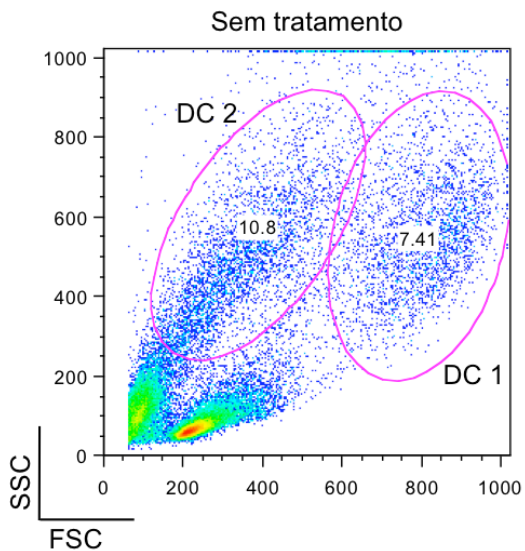

B

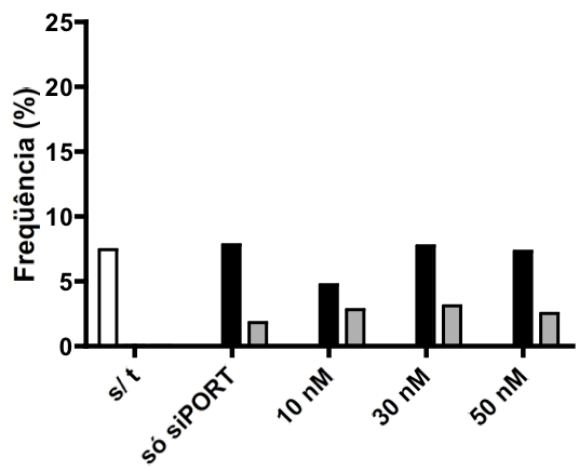

$3 \mu \mathrm{L}$ siPORT

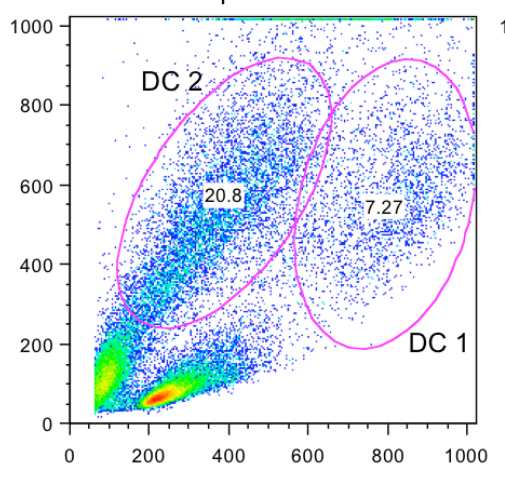

$5 \mu \mathrm{L}$ SIPORT

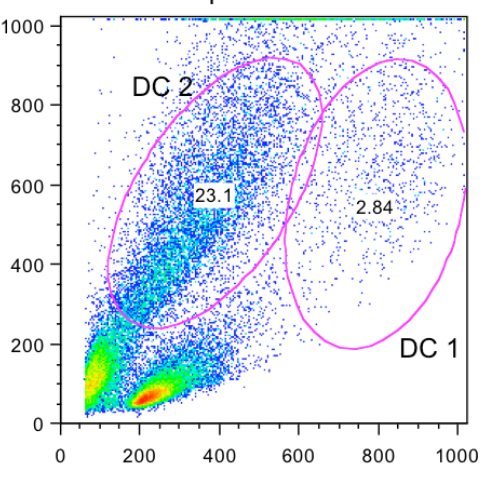

Gate DC 2

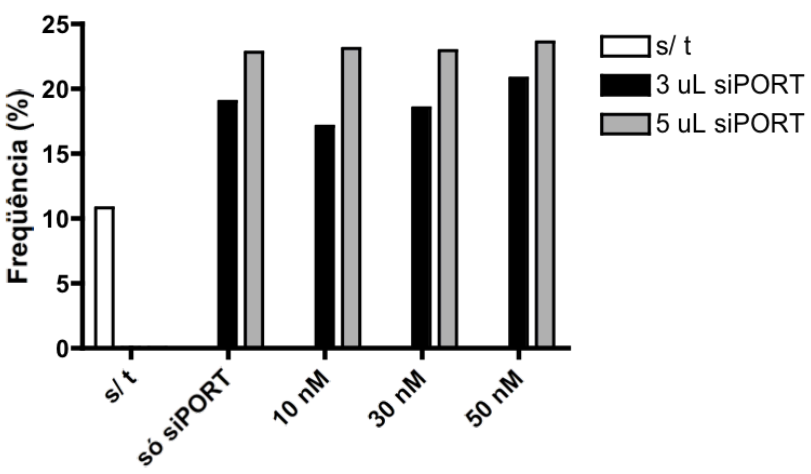

Figura 11 - Efeito do tratamento com siPORT sobre a distribuição morfológica de células do sexto dia de cultura. A e B: Gráficos pseudo-coloridos de tamanho (FSC) por granulosidade (SSC) (A) e porcentagem de células presentes nos gates DC 1 e DC 2 (B), 24 horas após a transfecção de células do sexto dia da cultura com 10, 30 ou $50 \mathrm{nM}$ de siRNA GAPDH-Cy3 e 3 ou $5 \mu \mathrm{L}$ do agente de transfecção siPORT, em comparação com células não transfectadas (sem tratamento) ou tratadas apenas com agente de transfecção.

O primeiro efeito observado após o tratamento foi uma alteração morfológica das células, aparecendo duas populações de granulosidade alta, mas com 
tamanhos diferentes, denominadas DC 1 e DC 2 nos gráficos da Figura 11. Estas populações estiveram também presentes no grupo sem tratamento. Com relação às populações DC 1 e DC 2, não foram observadas diferenças na porcentagem de células presentes nesses gates entre os grupos tratados com a mesma quantidade de agente de transfecção, ou seja, a presença do siRNA, mesmo que em concentrações crescentes, não causou alteração nas porcentagens das células presentes nos gates DC 1 e DC 2 em comparação à porcentagem de células presentes nesses mesmos gates no grupo tratado apenas com agente de transfecção (Figura 11B). Porém, enquanto a porcentagem de células presentes no gate DC 1 não variou nos grupos tratados com $3 \mu \mathrm{L}$ do agente de transfecção em comparação às células sem tratamento (cerca de 7\%), nos grupos tratados com $5 \mu \mathrm{L}$ do agente de transfecção observou-se diminuição da porcentagem de células do gate DC 1 (cerca de 2,5\%) tanto em comparação às células sem tratamento, como em comparação às tratadas com $3 \mu \mathrm{L}$ do agente de transfecção. Com relação ao gate DC 2, ambos os tratamentos ( $3 \mu \mathrm{L}$ e $5 \mu \mathrm{L}$ ) provocaram aumento da porcentagem de células presentes nesse gate (para cerca de $20 \%$ ) em comparação às células sem tratamento $(10,8 \%)$.

$\mathrm{Na}$ Figura 12 é possível observar os histogramas indicativos do resultado da transfecção com $3 \mu \mathrm{L}$ (topo) e com $5 \mu \mathrm{L}$ (base) de agente de transfecção nas diferentes concentrações de siRNA GAPDH-Cy3, nas populações de DC 1 (esquerda) e DC 2 (direita). Os valores indicados nos histogramas refletem as maiores porcentagens de transfecção observadas em cada caso ( $3 \mu \mathrm{L}: 26 \%$ para DC 1 e 17,2\% para DC 2; $5 \mu \mathrm{L}: 41,5 \%$ para DC 1 e $19 \%$ para DC 2). Em todos os experimentos de transfecção, as porcentagens de células transfectadas foram determinadas descontando-se os valores de auto-fluorescência observada nos grupos tratados apenas com agente de transfecção siPORT. 

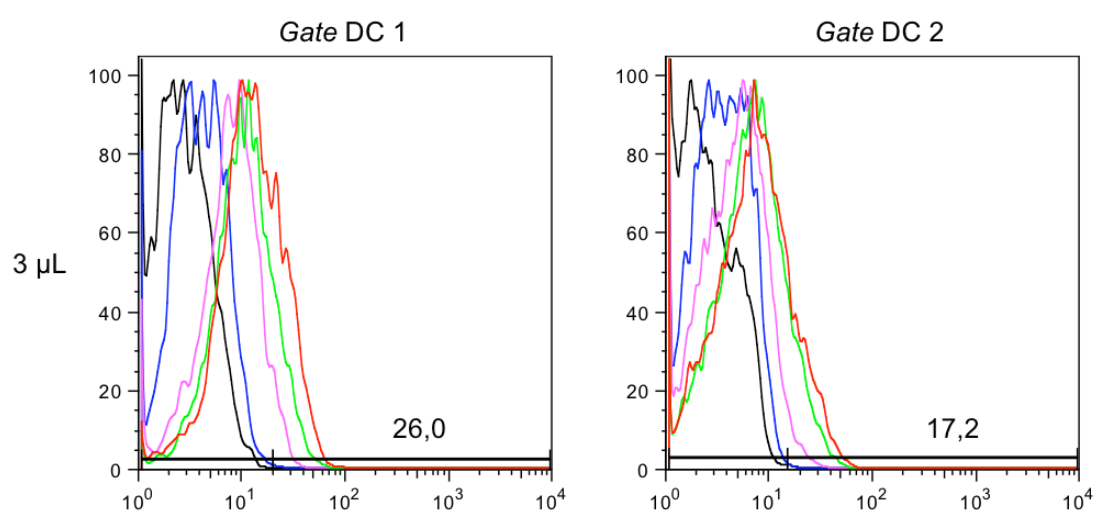

Sem tratamento

$3 \mu \mathrm{L}$ siPORT

SiRNA GAPDH-Cy3 10 nM

siRNA GAPDH-Cy3 30 nM

SiRNA GAPDH-Cy3 50 nM
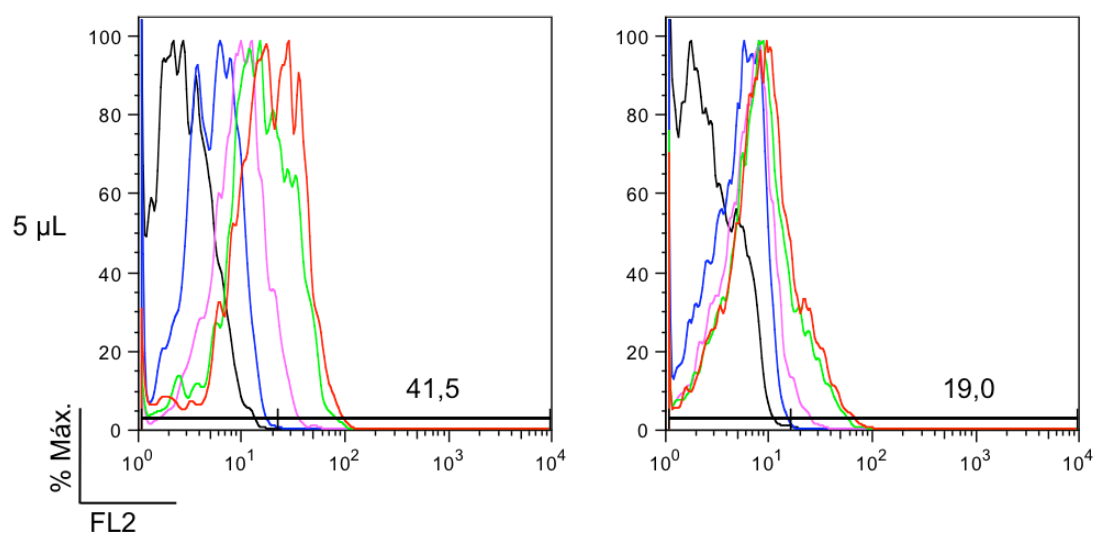

Sem tratamento

$5 \mu \mathrm{L}$ siPORT

siRNA GAPDH-Cy3 10 nM

SiRNA GAPDH-Cy3 30 nM

siRNA GAPDH-Cy3 50 nM

Figura 12 - Eficiência de transfecção de células dendríticas do sexto dia de cultura com o agente de transfecção siPORT. Histogramas das porcentagens de transfeção de células do sexto dia de cultura após 24 horas da transfecção com $3 \mu \mathrm{L}$ (topo) e $5 \mu \mathrm{L}$ (base) de agente de transfecção siPORT e concentrações de $10 \mathrm{nM}, 30 \mathrm{nM}$ e $50 \mathrm{nM}$ de siRNA GAPDH-Cy3, nas populações DC 1 e DC 2. Os valores indicados nos histogramas refletem as maiores porcentagens de transfecção observadas em cada caso.

Os resultados da eficiência de transfecção de cada grupo estão detalhados na Tabela 4. Estes indicam que, para uma mesma quantidade de agente de transfecção, o aumento da porcentagem de células transfectadas foi diretamente proporcional à concentração de siRNA, sendo que a quantidade de $5 \mu \mathrm{L}$ de agente de transfecção foi mais eficiente que a de $3 \mu \mathrm{L}$. Isso foi observado tanto para a população DC 1 quanto para a DC 2. Especificamente, para a população DC 1, as porcentagens de células transfectadas com a utilização de $3 \mu \mathrm{L}$ do agente de transfecção e $10 \mathrm{nM}, 30 \mathrm{nM}$ e $50 \mathrm{nM}$ de siRNA foram 5,2\%, 15,3\% e 26,0\%, respectivamente. Para essa mesma população, as porcentagens de transfecção com a utilização de $5 \mu \mathrm{L}$ do agente de transfecção e $10 \mathrm{nM}, 30 \mathrm{nM}$ e $50 \mathrm{nM}$ de siRNA foram 5,6\%, 30,2\% e 41,5\%, respectivamente. Para a população DC 2 a maior eficiência de transfecção observada com a utilização de $5 \mu \mathrm{L}$ do agente de transfecção não foi tão evidente: enquanto as porcentagens de transfecção com a 
utilização de $3 \mu \mathrm{L}$ do agente de transfecção e $10 \mathrm{nM}, 30 \mathrm{nM}$ e $50 \mathrm{nM}$ de siRNA foram de respectivamente $2,7 \%, 13,0 \%$ e 17,2\%, observou-se leve aumento para $3,4 \%, 15,9 \%$ e 19\% com a utilização de $5 \mu \mathrm{L}$ do agente de transfecção e $10 \mathrm{nM}, 30$ $\mathrm{nM}$ e $50 \mathrm{nM}$ de siRNA, respectivamente.

Tabela 4 - Porcentagem de células transfectadas com diferentes quantidades de siPORT e concentrações de siRNA. Porcentagens de células transfectadas após 24 horas da transfecção de células do sexto dia da cultura com 10, 30 ou 50 nM de siRNA GAPDHCy3 e 3 ou $5 \mu \mathrm{L}$ do agente de transfecção siPORT.

\begin{tabular}{ccccc}
\hline & & \multicolumn{3}{c}{ Células transfectadas (\%) } \\
\cline { 3 - 5 } População & siPNA & $10 \mathrm{nM}$ & $30 \mathrm{nM}$ & $50 \mathrm{nM}$ \\
& $3 \mu \mathrm{L}$ & 5,2 & 15,3 & 26,0 \\
\multirow{2}{*}{ DC 1 } & $5 \mu \mathrm{L}$ & 5,6 & 30,2 & 41,5 \\
& $3 \mu \mathrm{L}$ & 2,7 & 13,0 & 17,2 \\
\multirow{2}{*}{ DC 2} & $5 \mu \mathrm{L}$ & 3,4 & 15,9 & 19,0 \\
\hline
\end{tabular}

Pela análise dos resultados desse experimento, é possível afirmar que, embora a porcentagem de células presentes na população celular DC 1 tenha reduzido e na DC 2 aumentado com o tratamento em comparação às células sem tratamento, a maior eficiência de transfecção foi observada com utilização de $5 \mu \mathrm{L}$ do agente de transfecção siPORT e 50 nM de siRNA GAPDH-Cy3. Para confirmar se esse efeito era reproduzido na transfecção de células do quarto dia da cultura, realizaram-se novos experimentos mantendo-se esses parâmetros. Os resultados representativos de três experimentos podem ser observados na Figura 13. 
A

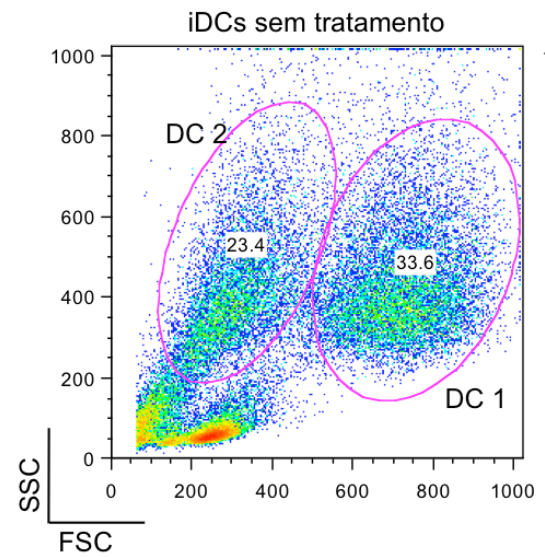

B
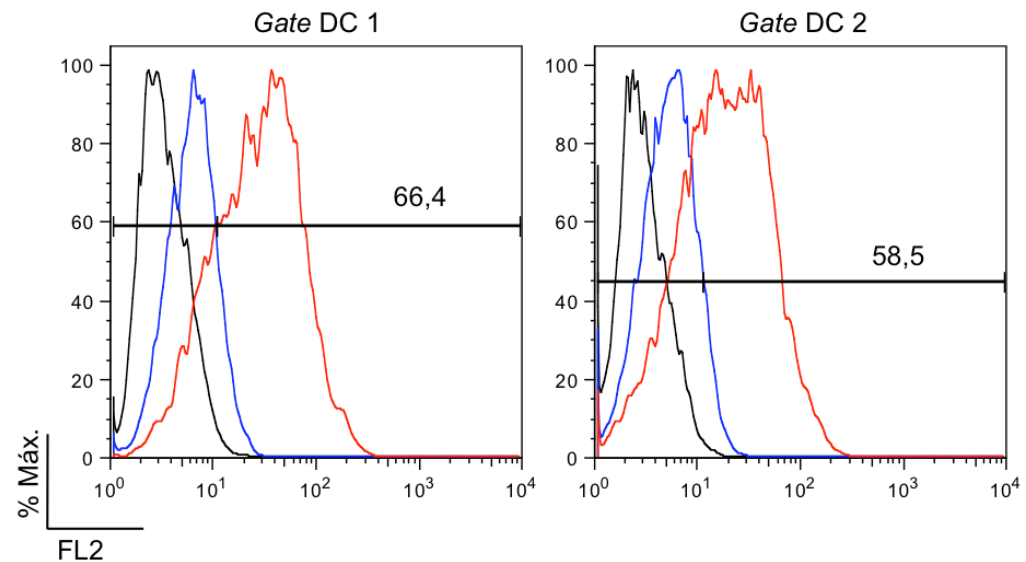

SIPORT

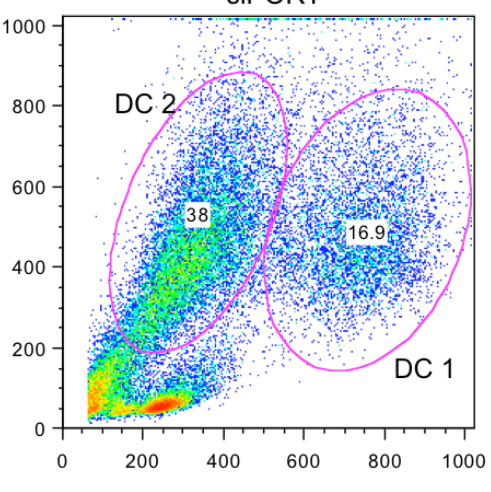

SiRNA GAPDH-y3

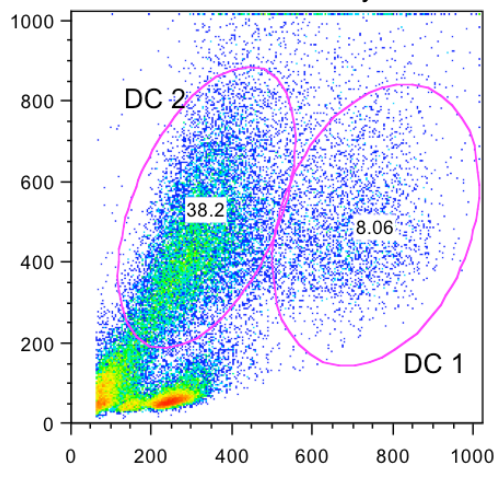

iDCs sem tratamento

$5 \mu \mathrm{L}$ siPORT

SiRNA GAPDH-Cy3 $50 \mathrm{nM}$

C SIPORT

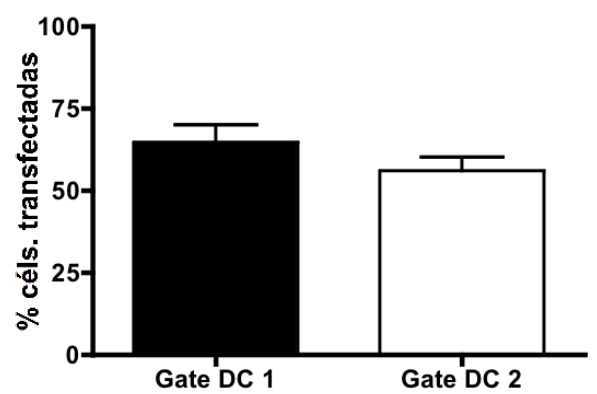

Figura 13 - Eficiência de transfecção de células dendríticas do quarto dia de cultura com o agente de transfecção siPORT. A e B: Gráficos pseudo-coloridos de tamanho (FSC) por granulosidade (SSC) (A) e histogramas indicativos das porcentagens de transfecção de células do quarto dia de cultura (B), após 24 horas da transfecção com $5 \mu \mathrm{L}$ de agente de transfecção siPORT e concentração de $50 \mathrm{nM}$ de siRNA GAPDH-Cy3, nas populações DC 1 e DC 2. Os valores indicados nos histogramas refletem as porcentagens de transfecção observadas nessas populações. C: Médias e desvios padrões obtidos a partir das porcentagens de células transfectadas com siRNA GAPDHCy3 e agente de transfecção siPORT em três experimentos independentes. 
Os gráficos pseudo-coloridos de tamanho por granulosidade indicaram que, assim como no experimento anterior, a porcentagem de células na população DC 2 aumentou nos grupos tratados em comparação ao grupo sem tratamento $(23,4 \%)$, embora não tenha variado entre o grupo tratado apenas com agente de transfecção $(38,0 \%)$ e aquele tratado com agente de transfecção e siRNA $(38,2 \%)$ (Figura 13A). Porém, diferentemente do observado no experimento anterior, a presença do siRNA parece ter causado redução na porcentagem de células presentes na população DC 1 para a metade $(8,06 \%)$, em comparação ao grupo tratado apenas com agente de transfecção (16,9\%). Este último grupo, por sua vez, também apresentou redução na porcentagem de células presentes na população DC 1 para cerca da metade em relação ao grupo sem tratamento $(33,6 \%)$. Com relação aos resultados da transfecção dessas células com o siRNA controle, os histogramas apresentados na Figura 13B indicaram que $66,4 \%$ e $58,5 \%$ das células presentes no gates DC 1 e DC 2 foram transfectadas, respectivamente. A partir das porcentagens de células transfectadas nas populações DC 1 e DC 2 obtidas a partir de três experimentos independentes, pôde-se calcular a média e o desvio padrão da eficiência de transfecção nessas populações, os quais foram de $64,7 \% \pm 5,2 \%$ e $56,1 \% \pm 4,1 \%$, respectivamente (Figura 13C). Pode-se concluir, portanto, que as células do quarto dia da cultura são eficientemente transfectadas com siRNA pela metodologia utilizada. Assim, mantiveram-se esses parâmetros para a realização dos experimentos subseqüentes.

Outra técnica utilizada para verificar a presença do siRNA no interior das células transfectadas foi a imunofluorescência (Figura 14). Para tanto, realizou-se transfecção de iDCs do quarto dia da cultura sobre lamínulas de vidro, que foram montadas sobre lâminas e analisadas em microscópio de fluorescência. A transfecção das células pode ser notada pela coloração vermelha das células (contra-coradas em azul com DAPI), uma vez que o siRNA GAPDH é conjugado ao fluorocromo Cy3. 


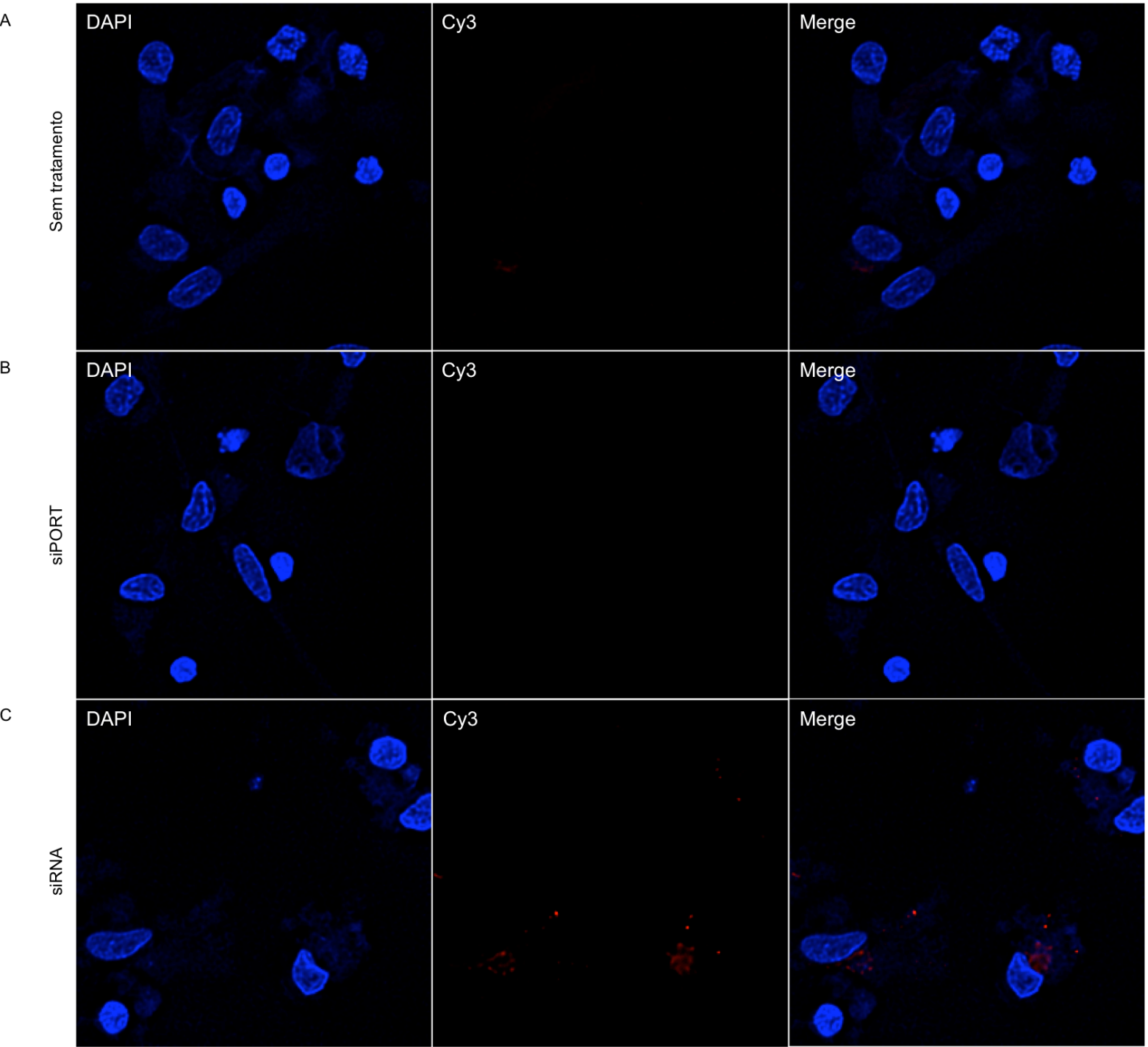

Figura 14 - Técnica de imunofluorescência para visualização da transfecção de células dendríticas imaturas do quarto dia de cultura com siRNA. Fotomicrografias retiradas após técnica de imunofluorescência 24 horas após transfecção de células do quarto dia da cultura com $5 \mu \mathrm{L}$ de agente de transfecção siPORT e concentração de 50 nM de siRNA GAPDH-Cy3 (C) e apenas com o agente de transfecção (B) em comparação com células sem tratamento $(A)$. Fotomicrografias retiradas com aumento de 400X.

\subsection{Utilização de siPORT para silenciamento das moléculas CD80 e CD86}

\subsubsection{Avaliação da viabilidade celular}

A viabilidade celular após os diferentes tratamentos foi avaliada 24 horas após a ativação das células com TNF-a (ou 48 horas após a transfecção de DCs do quarto dia da cultura), em três experimentos independentes, por exclusão do corante Azul de Tripan (Figura 15). 


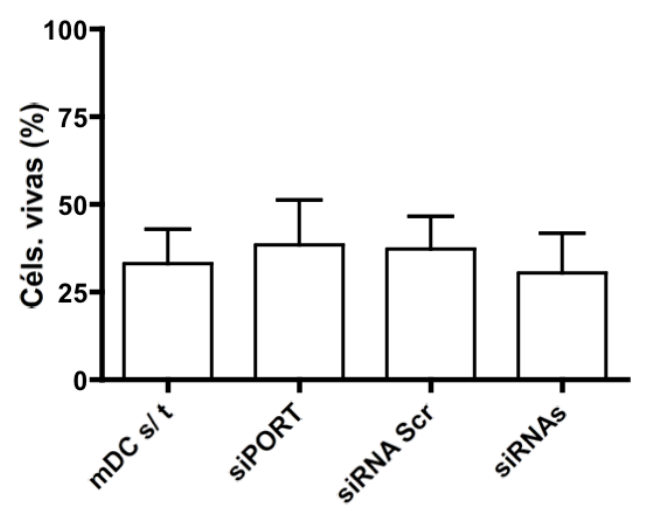

Figura 15 - Avaliação da viabilidade celular após tratamentos por exclusão do corante Azul de Tripan. Gráfico indicativo das médias e desvios padrões das porcentagens de células vivas 48 horas após a transfecção de células dendríticas do quarto dia da cultura, ativadas após 24 horas da transfecção, por exclusão do Azul do Tripan. No grupo siRNAs estão presentes médias obtidas após tratamentos com siRNA CD80-2 e siRNA CD86-2. Gráfico referente a três experimentos independentes. Análise estatísticas realizada pelo teste ANOVA seguido pelo teste de comparações múltiplas de Tukey-Kramer $(p>0,05)$.

As médias e desvios padrões das porcentagens de células vivas obtidos após cada tratamento foram: $33,03 \% \pm 9,89 \%$ nas mDCs sem tratamento, $38,4 \% \pm$ $12,83 \%$ no grupo tratado apenas com o agente de transfecção siPORT, $37,33 \% \pm$ $9,17 \%$ no grupo tratado com siPORT e siRNA Scr e $30,49 \% \pm 11,33 \%$ no grupo tratado com siPORT e siRNA CD80-2 ou siRNACD86-2. A análise estatística não revelou significância entre as diferenças $(p>0,05)$, indicando que os tratamentos com agente de transfeç̧ão siPORT ou siRNA não contribuem para a baixa viabilidade celular observada.

\subsubsection{Ausência de silenciamento das moléculas CD80 e CD86}

O silenciamento de CD80 com siRNA CD80-2 e de CD86 com siRNA CD86-2, os primeiros siRNAs adquiridos, foi tentado três vezes em cada caso. Células dendríticas do quarto dia da cultura foram transfectadas, ativadas 24 horas após a transfecção com TNF- $\alpha$, e o silenciamento avaliado após 24 horas da ativação. Os resultados podem ser observados na Figura 16. 
SIRNA CD80-2

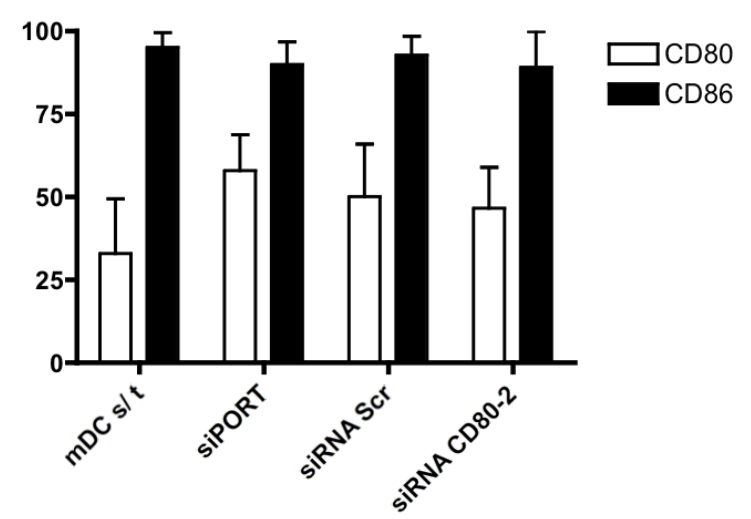

SiRNA CD86-2

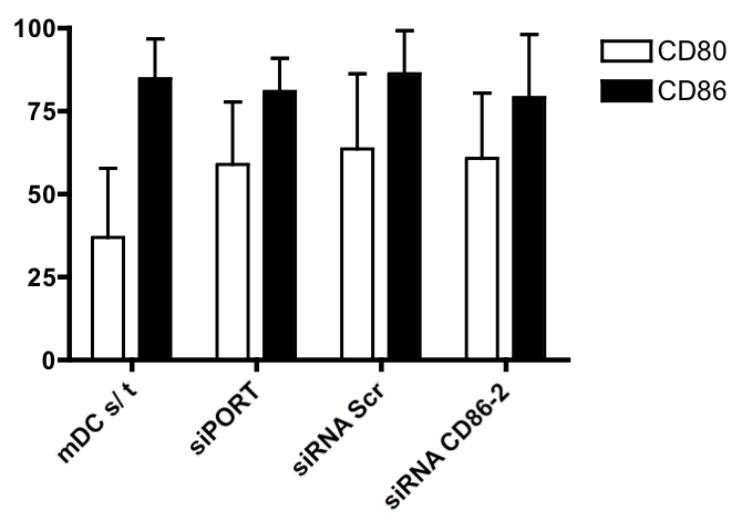

Figura 16 - Avaliação do silenciamento de CD80 e CD86 em DCs após 48 da transfecção com siRNAs. Gráficos indicando as porcentagens de células $\mathrm{CD}^{+} 0^{+}$e $\mathrm{CD} 6^{+}$após transfecção de DCs do quarto dia da cultura com siRNA CD80-2 e siRNA CD86-2, ativação com TNF- $\alpha 24$ horas após a transfecção, e avaliação do silenciamento após 24 horas da ativação. Análise estatísticas realizada pelo teste ANOVA seguido pelo teste de comparações múltiplas de Tukey-Kramer $(p>0,05)$.

Tanto na análise de cada experimento individualmente, como na análise conjunta dos experimentos numa repetição de três para cada molécula, não foram observadas diferenças significativas entre os grupos tratados com siRNAs específicos e seus respectivos controles $(p>0,05)$. Isso foi observado tanto na avaliação da porcentagem de células positivas para cada molécula, como indicado nos gráficos da Figura 16, como na análise da MFI em cada experimento.

Observou-se, porém, aumento da porcentagem de células $\mathrm{CD} 80^{+}$no tratamento com agente de transfeção siPORT quando comparado com as mDCs sem tratamento, tanto nos experimentos de tentativa de silenciamento de CD80, quanto nos de CD86. Embora esse aumento não tenha se mostrado significativo, sugere possível efeito de ativação das DCs com a utilização do agente de transfecção.

\subsection{Utilização de iMAX para silenciamento das moléculas CD80 e CD86}

Diante da ausência de silenciamento observada com a utilização do agente de transfecção siPORT, testou-se, utilizando a mesma metodologia padronizada, o agente de transfecção iMAX. 


\subsubsection{Avaliação da eficiência de transfecção}

Primeiramente avaliou-se a eficiência de transfecção do agente iMAX em três experimentos independentes. Para isso, iDCs do quarto dia da cultura foram transfectadas de acordo com a metodologia descrita (item 3.4) e avaliadas por citometria de fluxo quanto à fluorescência das células transfectadas com siRNA GAPDH-Cy3 após 24 horas da transfecção (Figura 17).

A
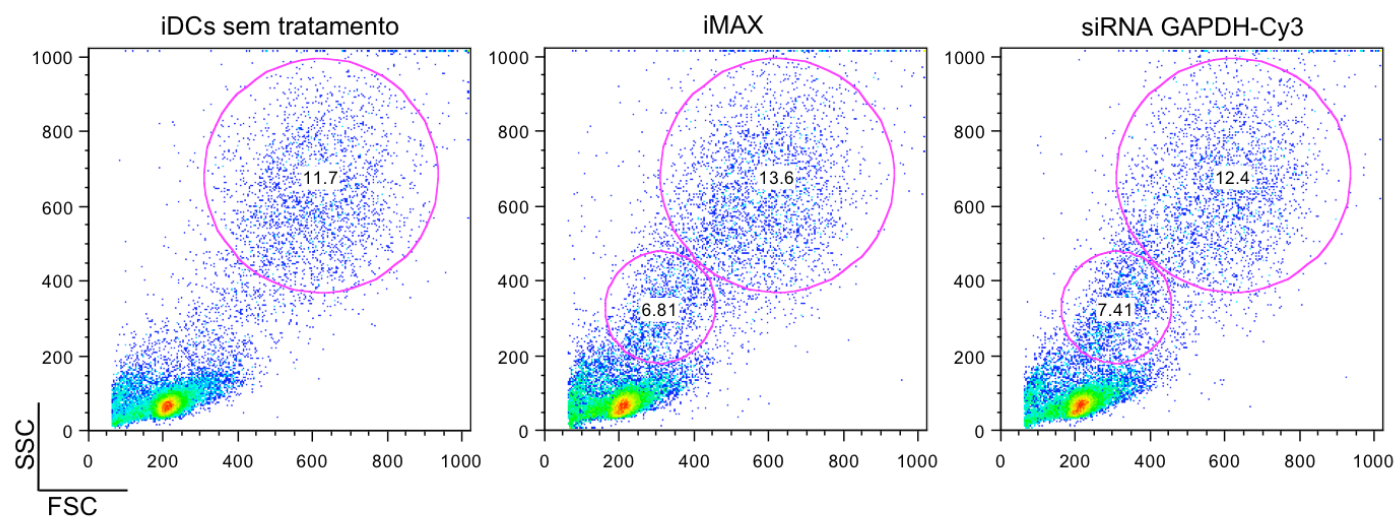

B

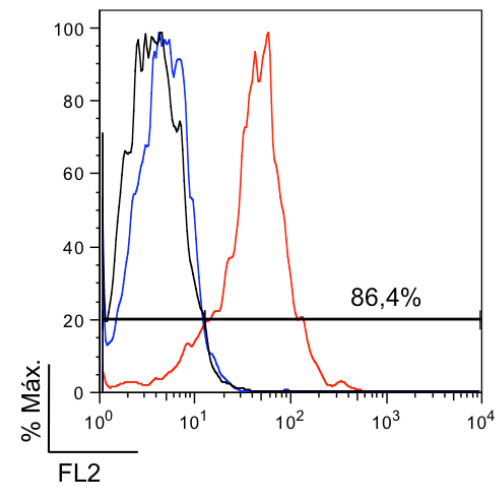

iDCs sem tratamento iMAX

SiRNA GAPDH-Cy3
C

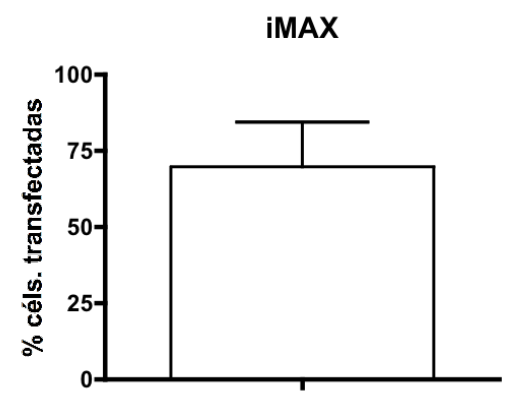

Figura 17 - Eficiência de transfecção de células dendríticas do quarto dia de cultura com o agente de transfecção iMAX. Gráficos pseudo-coloridos de tamanho (FSC) por granulosidade (SSC) (A) e histogramas indicativos das porcentagens de transfecção de células do quarto dia de cultura (B), após 24 horas da transfecção com $5 \mu \mathrm{L}$ de agente de transfecção siPORT e concentração de 50 nM de siRNA GAPDH-Cy3, nas populações DC 1 e DC 2. O valor indicado no histograma reflete a porcentagem de transfecção observada em um experimento. C: Média e desvio padrão obtidos a partir das porcentagens de células transfectadas com siRNA GAPDH-Cy3 e agente de transfecção iMAX em três experimentos independentes.

Os gráficos pseudocoloridos de tamanho por granulosidade de um experimento representativo indicaram, após 24 horas da transfecção, a presença de uma população grande e granulosa, correspondente ao esperado para DCs, onde a análise foi efetuada. Porém, foi possível observar no grupo tratado com agente de 
transfecção iMAX ou com agente de transfecção e siRNA GAPDH-Cy3, a presença de uma população de menor tamanho e granulosidade do que as DCs, porém mais granulosas que os linfócitos, não observado no grupo de células não tratadas. Apesar disso, a porcentagem de células presentes no interior dos gates não se alterou, sendo de $11,7 \%, 13,6 \%$ e $12,4 \%$ nos grupos sem tratamento, tratado com agente de transfecção iMAX ou agente de transfecção e siRNA GAPDH-Cy3, respectivamente (Figura 17A). Isso pode ter ocorrido pois as iDCs sem tratamento se encontravam fortemente aderidas à placa, enquanto que as DCs tratadas com agente de transfecção iMAX ou agente de transfecção e siRNA GAPDH-Cy3 se encontravam soltas no meio, contribuindo para uma menor recuperação de iDCs sem tratamento em comparação às DCs tratadas. Isso é consistente com o efeito de "ativação" das células pelo agente de tranfecção iMAX, também observado com o agente de transfecção siPORT (item 4.4.2).

Quanto à eficiência de transfecção, o resultado de um experimento pode ser observado em histograma na Figura 17B, indicando transfecção de $86,4 \%$ das células, e em gráfico na figura 17C, indicando média de transfecção e desvio padrão obtidos a partir das porcentagens de células transfectadas em três experimentos independentes, que foram de 69,7\% \pm 14,5\%. A eficiência da transfecção de células com siPORT (Figura 13C, gate DC 1) e iMAX (Figura 17C) não diferiu significativamente $(p>0,05)$. Pode-se concluir, portanto, que as células do quarto dia da cultura são eficientemente transfectadas com siRNA pelo agente de transfecção iMAX. Assim, este passou a ser o agente de transfecção utilizado nos experimentos subseqüentes.

\subsubsection{Avaliação da viabilidade celular}

A viabilidade celular após os diferentes tratamentos foi avaliada 48 horas após a transfecção de DCs do quarto dia da cultura, tanto por exclusão do corante Azul de Tripan, como por marcação das células com anexina e PI (Figura 18). 
A

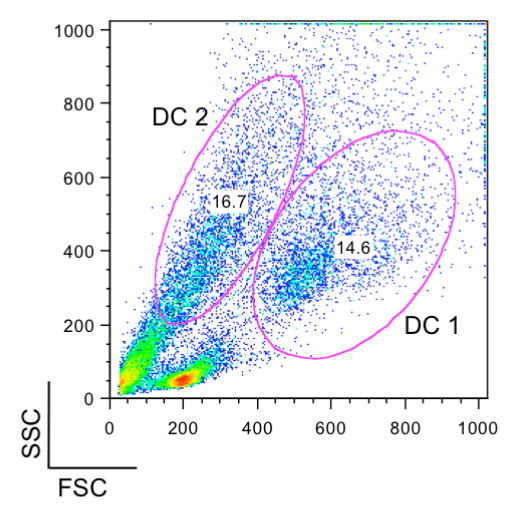

B

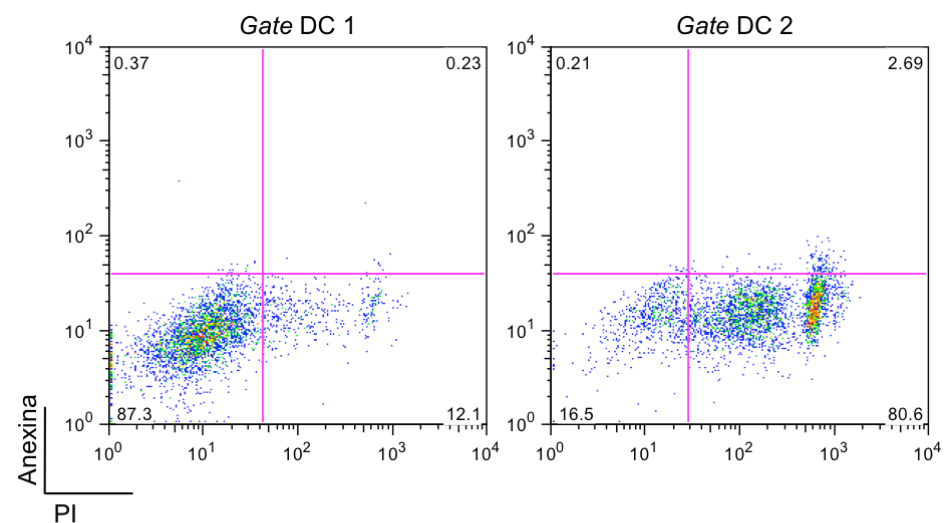

D
C

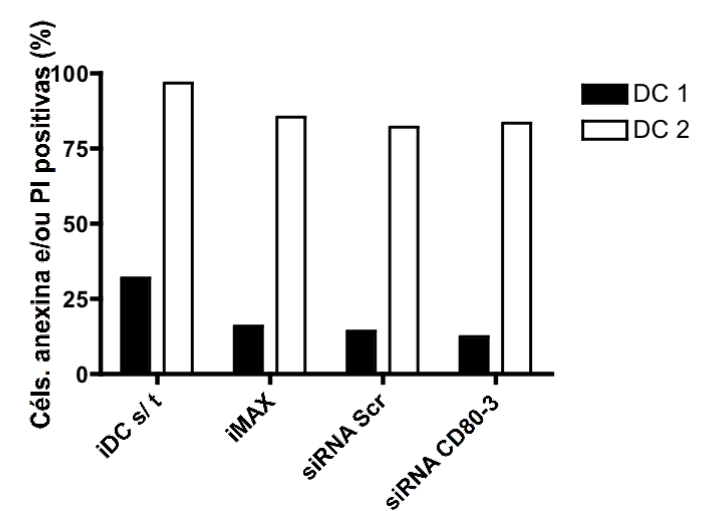

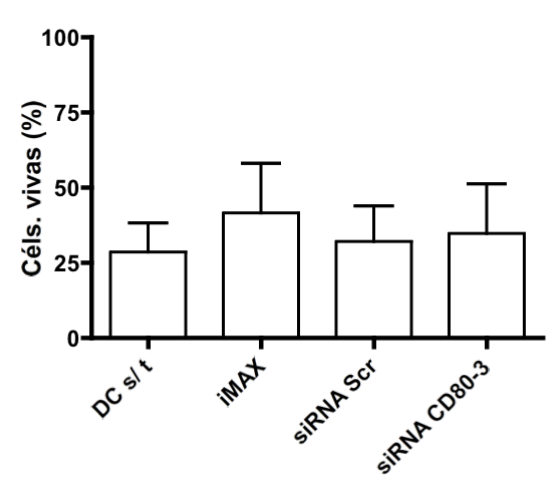

Figura 18 - Avaliação da viabilidade celular após tratamentos por marcação com anexina-PI e exclusão do corante Azul de Tripan. A e B: Gráficos pseudo-coloridos de tamanho (FSC) por granulosidade (SSC) representativo de todos os grupos experimentais, indicando os gates DC 1 e DC 2 para análise da porcentagem de células mortas (A), representadas nos gráficos de $\mathrm{PI}$ por anexina (B) em cada população, 48 horas após a transfecção de células dendríticas do quarto dia da cultura. C: Gráfico indicativo das porcentagens de células mortas, avaliadas por marcação com anexina e/ou PI, presentes nos gates DC 1 e DC 2, 48 horas após a transfecção de células dendríticas do quarto dia da cultura. D: Gráfico indicativo das médias e desvios padrões das porcentagens de células vivas 48 horas após a transfecção de células dendríticas do quarto dia da cultura, ativadas ou não, por exclusão do Azul do Tripan. Gráfico referente a quatro experimentos independentes. Análise estatísticas realizada pelo teste ANOVA seguido pelo teste de comparações múltiplas de Tukey-Kramer $(p>0,05)$.

Na Figura 18A é possível observar que, após 48 horas da transfecção, já são distinguíveis duas populações de células granulosas de tamanhos diferentes, semelhantes às populações DC 1 e DC 2 observadas no tratamento com siPORT. Entretanto, enquanto o tratamento com siPORT levou ao parecimento dessas populações já 24 horas após a transfecção (Figura 13A), o tratamento com iMAX só permitiu a identificação das duas populações após 48 horas (Figura 18A).

$\mathrm{A}$ análise da porcentagem de células marcadas com anexina e/ou $\mathrm{PI}$ dentro dos gates DC 1 e DC 2 pode ser observada na Figura 18C. As porcentagens de células mortas na população DC 1 após cada tratamento foram: 31,8\% nas iDCs sem tratamento, $15,9 \%$ no grupo tratado apenas com o agente de transfecção iMAX, 
$14,12 \%$ no grupo tratado com iMAX e siRNA Scr e $12,3 \%$ no grupo tratado com iMAX e siRNA CD80-3. Essas porcentagens na população DC 2 foram de respectivamente $96,6 \%, 85,4 \%, 82,0 \%$ e $83,3 \%$. Torna-se, pois, evidente, que a população DC 2 é composta principalmente por células mortas, enquanto que a DC 1 é composta em sua maioria por células vivas (Figura 18B). A partir dessas observações, considerou-se apenas o gate DC 1 para análise de fenótipo de células dendríticas após a transfecção. Vale ressaltar que, embora tenha sido observado diminuição de viabilidade de células presentes no gate DC 1 para a metade nos tratamentos contendo agente de transfecção (Figura 18C), em comparação as iDCs sem tratamento, o que aponta para citotoxicidade do agente de transfeção, os resultados se referem a um experimento, o que impossibilita que tiremos conclusões seguras.

Também avaliou-se a viabilidade celular após os diferentes tratamentos, por exclusão do corante Azul de Tripan, em quatro experimentos independentes (Figura 18D). Isso foi realizado 48 horas após a transfecção de DCs do quarto dia da cultura, ativadas ou não 24 horas após a transfecção. As médias e desvios padrões das porcentagens de células vivas obtidos após cada tratamento foram: $28,51 \% \pm$ $9,67 \%$ nas DCs sem tratamento, $41,5 \% \pm 16,53 \%$ no grupo tratado apenas com o agente de transfecção iMAX, 32,04\% $\pm 11,89 \%$ no grupo tratado com iMAX e siRNA Scr e $34,72 \% \pm 16,55 \%$ no grupo tratado com iMAX e siRNA CD80-3. Semelhante ao observado no tratamento de transfecção com siPORT, a análise estatística não revelou significância entre as diferenças $(p>0,05)$, indicando que os tratamentos com agente de transfeç̧ão siPORT ou siRNA não contribuem para a baixa viabilidade celular observada.

\subsubsection{Silenciamento de CD80}

Células do quarto dia da cultura para diferenciação foram retiradas, transfectadas de acordo com o protocolo descrito no item 3.4, não ativadas por citocinas, e a capacidade de silenciamento dos siRNAs CD80-1, CD80-2 e CD80-3 foi avaliada após 48 horas da transfecção, por fenotipagem das células por citometria de fluxo e por PCR em tempo real. Os resultados de um experimento encontram-se na Figura 19 e são equivalentes aos encontrados numa repetição do mesmo. 

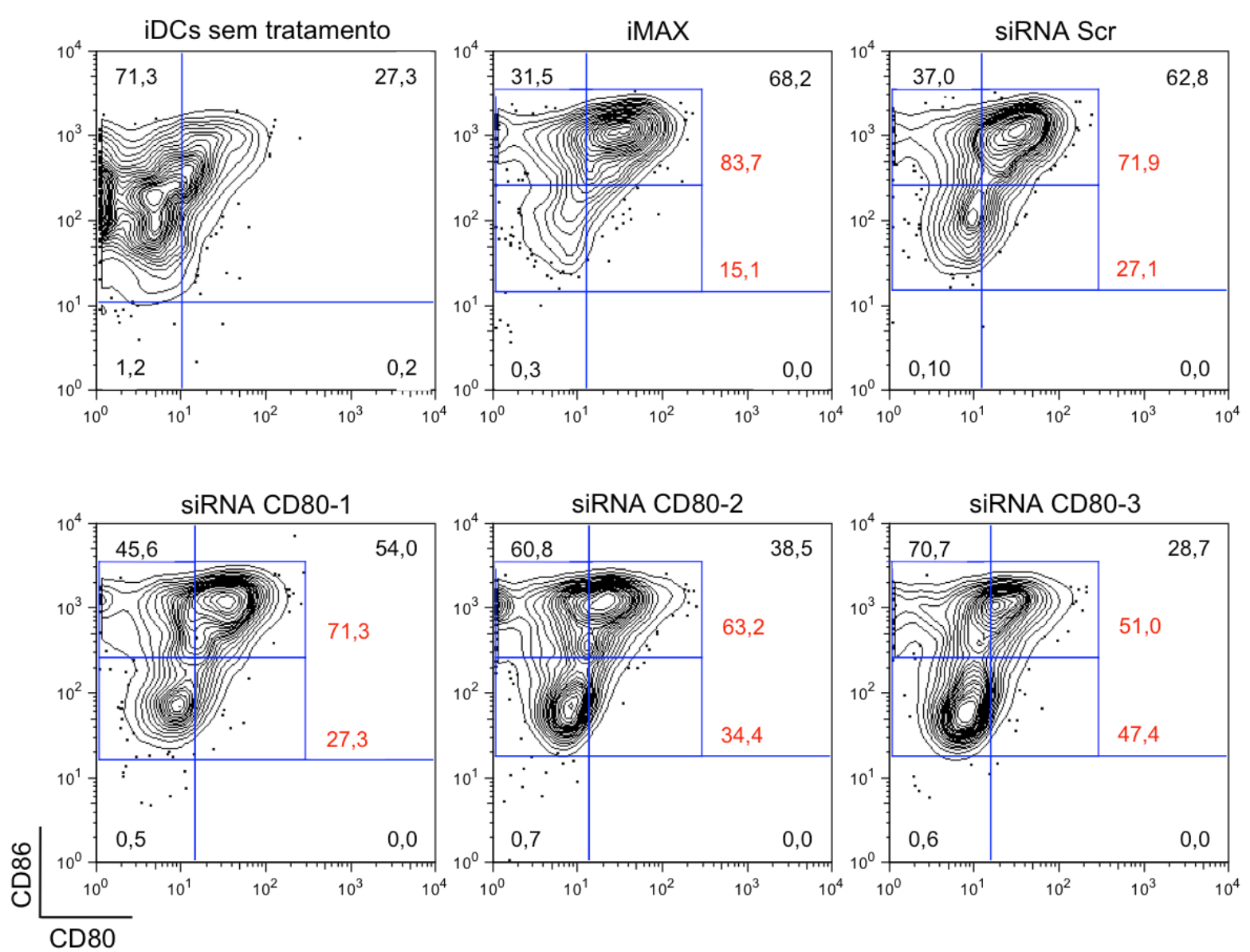

Figura 19 - Silenciamento de CD80 em DCs após 48 da transfecção com siRNAs. Gráficos contour de CD80 por CD86 em DCs avaliadas após 48 horas da transfecção, em gate de células positivas para essas moléculas, com iMAX, iMAX e siRNAs específicos para CD80 (siRNA CD80-1, CD80-2 e CD80-3), iMAX e siRNA sem capacidade de silenciamento - scrambled (Scr) ou iDCs não tratadas. Os gates em azul delimitam as populações CD86hi e CD86low, e as respectivas porcentagens se encontram em vermelho.

Chama a atenção nesta figura, além do silenciamento de CD80 (o qual também pode ser visualizado na Figura 20A), mais evidente com a utilização do siRNA CD80-3, o aumento de uma população $\mathrm{CD}^{+} 6^{+}$, porém com menor intensidade de marcação. Este aumento é melhor identificado na Figura 20B, que mostra o histograma da expressão de CD86 nas DCs submetidas ao silenciamento de expressão de CD80. Ainda, é interessante notar que o tratamento das células apenas com agente de transfecção iMAX causa um aumento na freqüência de células $\mathrm{CD}^{\circ} 0^{+} \mathrm{CD} 86^{+}$(Figura 19). 

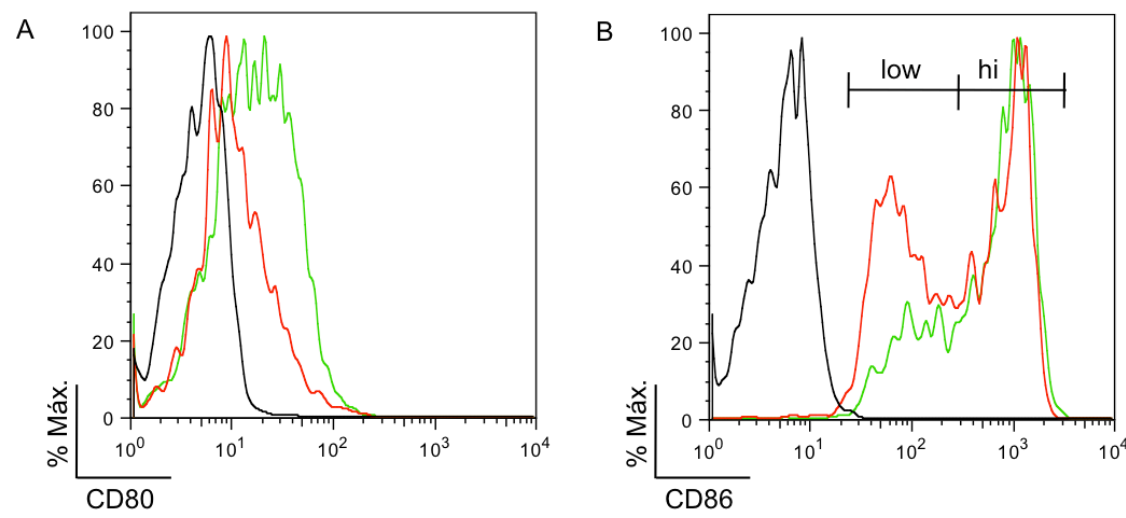

Controle negativo

SiRNA Scr

siRNA CD80-3

Figura 20 - Histogramas da expressão de CD80 e CD86 em DCs 48 horas após tratamento com siRNAs. A: Histograma da expressão de CD80 em DCs 48 horas após tratamento com siRNA CD80-3 em comparação com siRNA Scr e DCs não marcadas (controle negativo). B: Histograma da expressão de CD86 em DCs 48 horas após tratamento com siRNA CD80-3 em comparação com siRNA Scr e DCs não marcadas (controle negativo).

Em seguida verificou-se o silenciamento por PCR em tempo real. A Figura 21 mostra os resultados obtidos. Chama a atenção, ao lado do silenciamento por dois dos três siRNAs usados, também uma diminuição de expressão de outros mRNAs característicos das DCs, como HLA-DR e CD83. Porém, nestes casos, a diminuição não foi diferente da obtida com o tratamento com o siRNA Scr. 
CD80

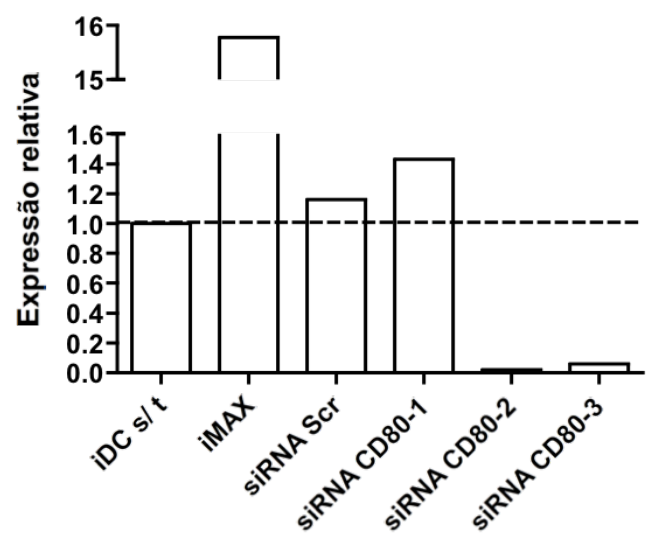

HLA-DR

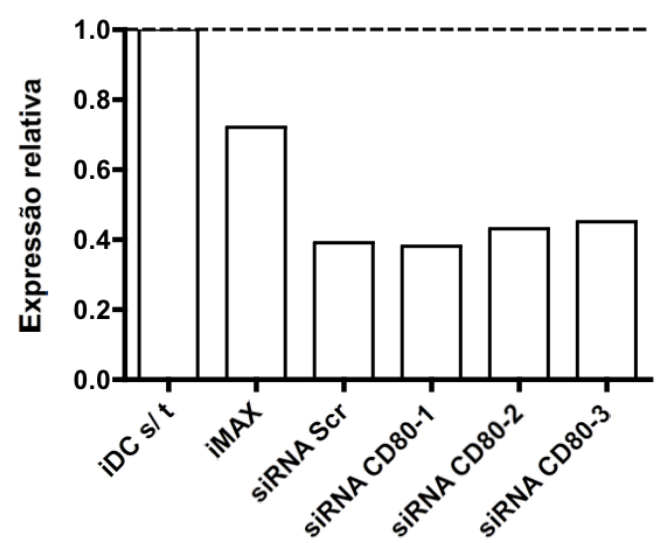

CD86

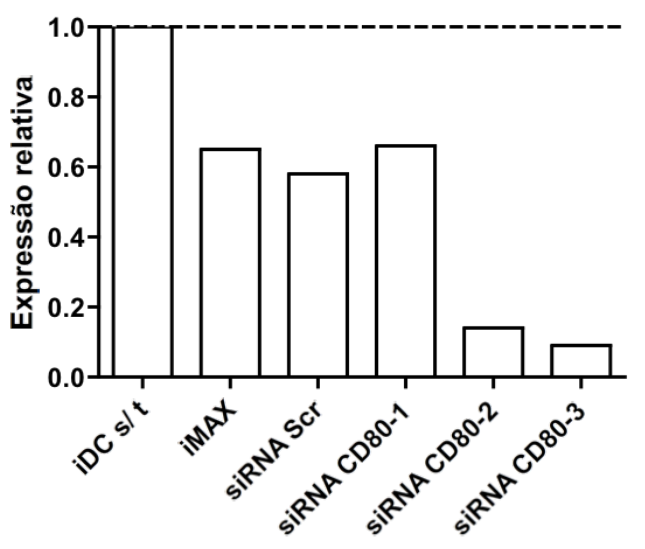

CD83

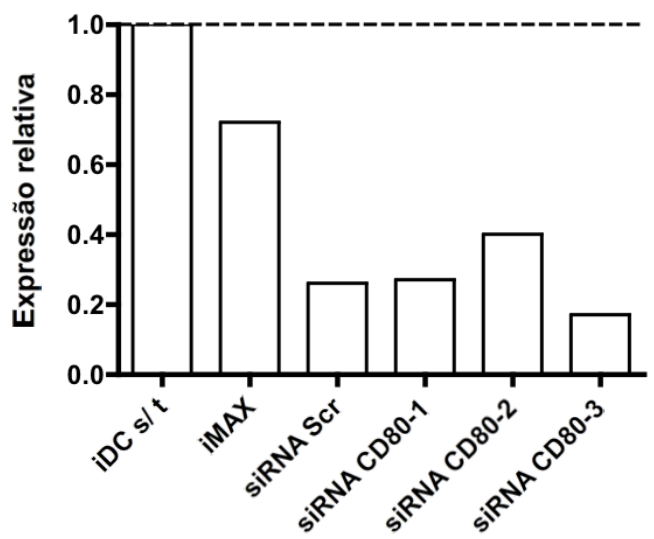

Figura 21 - Expressão relativa de CD80, CD86, HLA-DR e CD83 por PCR em tempo real em DCs 48 horas após tratamento com siRNAs. Expressão relativa do mRNA das moléculas CD80, CD86, HLA-DR e CD83 por PCR em tempo real a partir de RNA total extraído de DCs 48 horas após tratamento apenas com agente de transfecção iMAX ou iMAX e siRNAs Scr, CD80-2, CD80-2 e CD80-3, em comparação com iDCs não tratadas.

\subsubsection{Silenciamento de CD86}

Tendo-se em vista que a molécula CD86 é constitutivamente expressa desde os monócitos, avaliou-se o silenciamento nessas células, após seleção positiva das células $\mathrm{CD} 14^{+}$por beads magnéticas. Vinte e quatro horas após a transfecção, os monócitos foram ativados com coquetel de ativação, e a avaliação do silenciamento foi efetuada 24 horas após a ativação. Os resultados de um experiemento podem ser observados nas Figuras 22 e 23. 

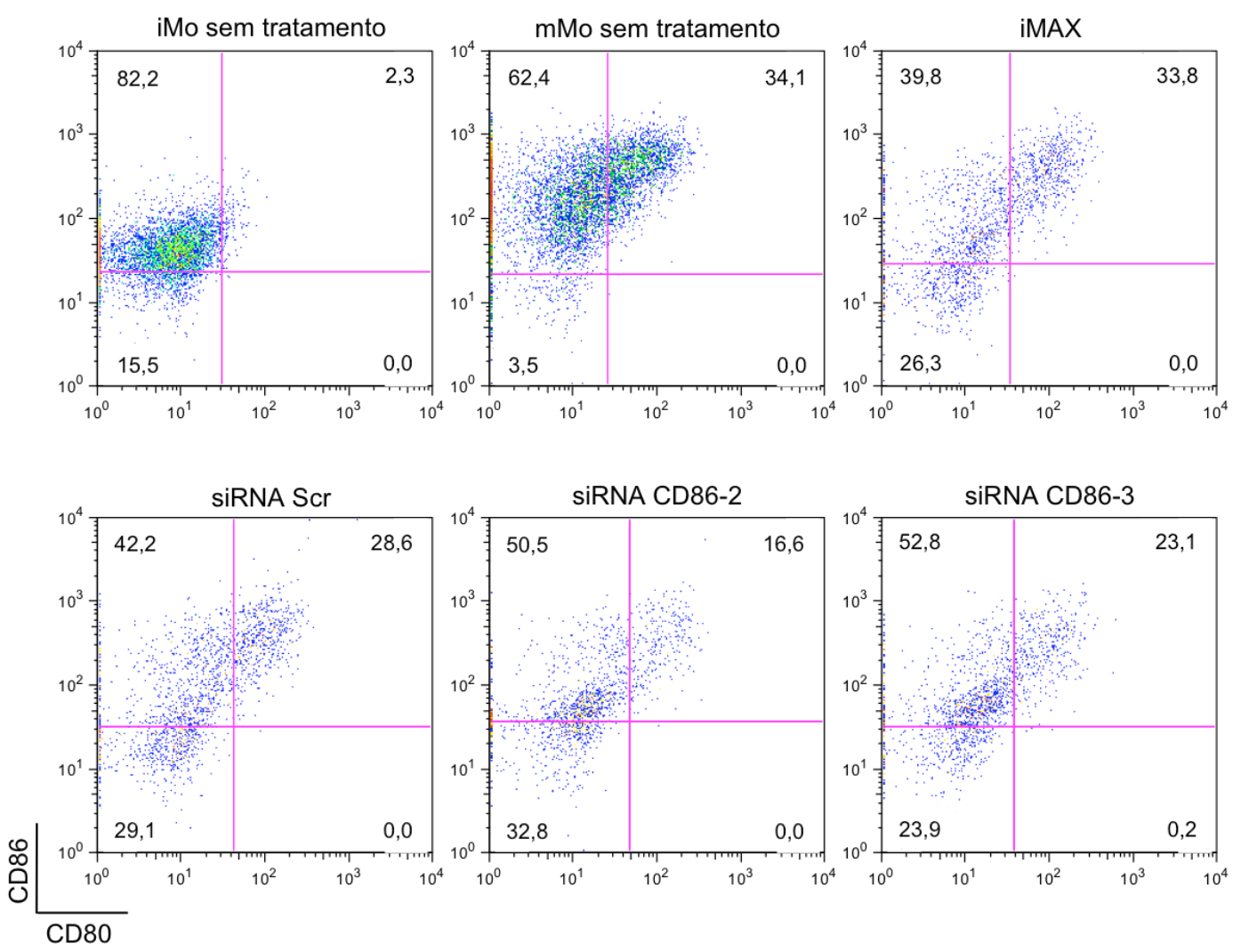

Figura 22 - Silenciamento de CD86 em monócitos após 48 horas da transfecção com siRNAs. Gráficos pseudocoloridos de CD80 por CD86 em monócitos avaliados após 48 horas da transfecção (24 horas da ativação com coquetel de ativação), com iMAX, iMAX e siRNAs específicos para CD86 (siRNAs CD86-2 e CD86-3), iMAX e siRNA sem capacidade de silenciamento - scrambled (Scr) ou monócitos não tratados, ativados (mMo sem tratamento) ou não (iMo sem tratamento).

Os resultados deste experimento indicam leve diminuição de porcentagem de células $\mathrm{CD}^{+}{ }^{+}$com a utilização do siRNA CD86-2, em comparação com o tratamento com siRNA Scr. Enquanto a porcentagem de células CD $86^{+}$foi de $70,8 \%$ no grupo tratado com siRNA Scr, esta foi de $67,1 \%$ no grupo tratado com siRNA CD86-2.

Embora esta diminuição tenha sido muito discreta, os histogramas mostrando a intensidade de expressão dessa molécula nas células positivas (Figura 23B) indicam diminuição consistente da população $\mathrm{CD} 86^{\mathrm{hi}} \mathrm{com}$ conseqüente aumento da população CD86 ${ }^{\text {low }}$. A análise da expressão da molécula CD80 (Figura 23B) indica diminuição com o silenciamento de CD86, fenômeno semelhante ao observado no silenciamento de CD80 em DCs, em que se observa diminuição da poulação CD86 ${ }^{\text {hi }}$ e aumento da CD86 ${ }^{\text {low }}$ (Figura 20). 
A

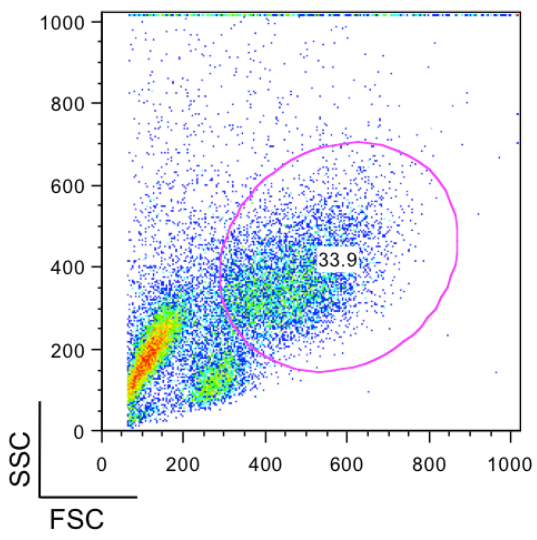

B
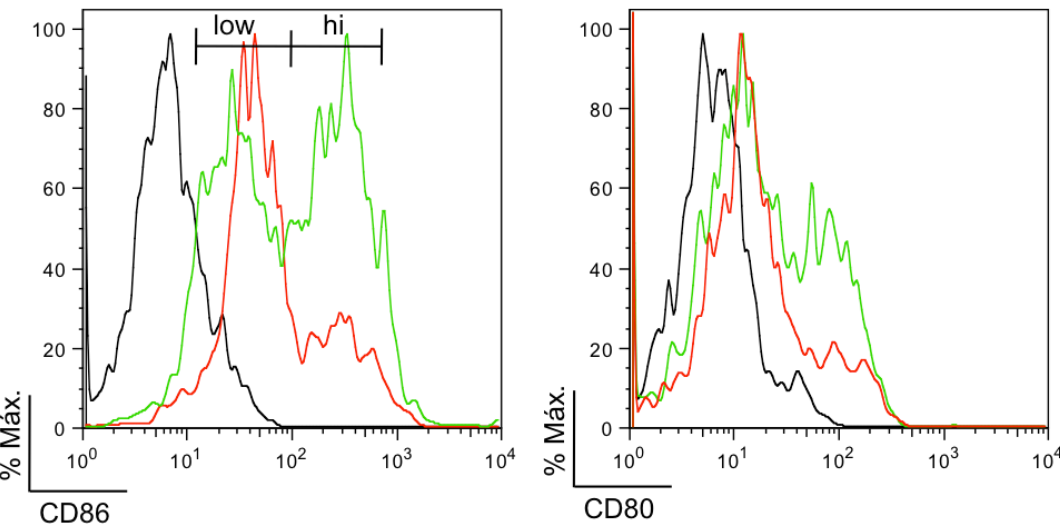

Controle negativo

SiRNA Scr

SiRNA CD86-2

Figura 23 - Histogramas da expressão de CD80 e CD86 em Mo 48 horas após tratamento com siRNAs. A: Histograma da expressão de CD80 em DCs 48 horas após tratamento com siRNA CD80-3 em comparação com siRNA Scr e DCs não marcadas (controle negativo). B: Histograma da expressão de CD86 em DCs 48 horas após tratamento com siRNA CD80-3 em comparação com siRNA Scr e DCs não marcadas (controle negativo). 
5 DISCUSSÃO 
Neste estudo foram estabelecidas as condições de transfecção de células dendríticas derivadas de monócitos de doadores saudáveis com siRNA. Estas foram inicialmente padronizadas com o uso de siRNA controle marcado com fluorescência. Uma vez estabelecidas as condições basais, foi possível identificar o protocolo mais adequado para silenciamento de CD80. Dos três siRNAs utilizados, um deles mostrou-se mais eficiente, atingindo o silenciamento (de cerca de 55\%) da positividade do CD80 nas DCs, 48 horas após a transfecção. Também foi possível, por meio da transfecção de monócitos, modular a expressão da molécula CD86. Na tentativa de otimizar o protocolo de silenciamento, avaliou-se a cinética de expressão do mRNA de CD80 e CD86 durante cultura para diferenciação em DCs (em meio de cultura AIM-V , ativadas com TNF- $\alpha$ ), tendo-se notado que a expressão do CD80 sofre aumento significativo poucas horas após o estímulo com citocinas usadas para induzir a diferenciação das DCs e que a expressão das duas é aumentada pelo tratamento com TNF- $\alpha$. Outra observação intrigante foi a de que o silenciamento só foi conseguido em DCs não submetidas à estímulo para ativação. Por fim, avaliou-se o efeito do silenciamento de uma molécula co-estimuladora sobre a expressão da outra, tendo-se notado uma aparente co-modulação de sua expressão.

O processo de maturação da célula dendrítica é uma etapa crucial para a ativação de linfócitos $T$ virgens. Durante este processo, a DC sofre alterações em moléculas da superfície, como o aumento da expressão das moléculas coestimuladoras CD80 e CD86. A inibição da maturação, por sua vez leva à indução de tolerância e supressão de respostas imunes indesejadas (BANCHEREAU e STEINMAN, 1998; LUTZ e SCHULER, 2002). Assim, a compreensão dos mecanismos responsáveis pela maturação das DCs e das características que conferem a essas células sua capacidade imunomoduladora é fundamental. Neste ponto, chamam a atenção, dados que mostram associação da expressão de CD80 e CD86, moléculas tipicamente afetadas pela maturação das DCs, com o câncer, doenças auto-imunes e a rejeição/aceitação de transplantes (STEINMAN e BANCHEREAU, 2007).

Neste contexto, muitos são os estudos que examinaram o papel dessas moléculas em diferentes condições e modelos, com resultados muitas vezes contrastantes, os quais atribuem às moléculas ora papéis equivalentes, ora distintos, tanto na capacidade de ativação de linfócitos $T$, quanto na de diferenciação das 
subpopulações de linfócitos T auxiliares. Assim, propôs-se este estudo, que visa aplicar a tecnologia de silenciamento por RNA de interferência, para, modulando especificamente cada uma destas moléculas, melhor entender o papel coestimulador gerado por elas.

Apesar desta proposta inicial, tornou-se claro que o grande desafio do projeto seria obter o silenciamento das moléculas de interesse em DCs. Na verdade, é relatado na literatura que o silenciamento destas moléculas é difícil (GU et al., 2006; PEDERSEN; FANG; PEDERSEN, 2009), e até o momento apenas descrito para DCs murinas. Antes mesmo deste ponto, porém, surgiu outro obstáculo: a heterogeneidade das células submetidas ao silenciamento. DCs cultivadas em meio AIM-V e ativadas com TNF- $\alpha$ diferem das células cultivadas em meio RPMI-1640 e diferem, ainda, entre si, dependendo de fatores nem sempre controláveis (NEVES, 2003). Tanto a molécula CD80 como CD86 variam muito em freqüência entre diferentes doadores, como demonstrado no item 4.1. Particulamente, observou-se que a ativação das células com TNF-a não causou boa indução de expressão da molécula CD80, cuja mediana de células positivas caiu de iDCs para mDCs, apesar de ter havido um aumento na média da MFI para essa molécula nessas células. Esse aumento, porém, não foi significativo. Isso pode estar relacionado a um pequeno número de culturas avaliadas no sétimo dia, em comparação ao quinto dia. Também não se pode descartar o fato de que, ao final do sétimo dia as mDCs ativadas, as quais foram cultivadas em meio AIM-V, na ausência de soro, pudessem estar carenciadas devido ao aumento da ativadade metabólica induzido pelo TNF- $\alpha$, uma vez que não se adicionou novo meio à cultura, nem se suplementou a cultura com adição de citocinas.

Para as demais moléculas, de maneira geral, também foram observadas variações com relação à freqüência de células positivas, algumas vezes mais presentes em determinado momento da cultura, como é o caso de CD1a e CD40 em iDCs e CD83 em mDCs. Já a freqüência de células positivas para a molécula CD123 variou ao longo de toda a cultura. Enquanto a MFI das moléculas CD1a, CD123 e, em menor intensidade CD83, acompanhou o padrão observado para a freqüência, observou-se aumento da MFI das células positivas para CD40 de iDCs para mDCs, embora esse aumento tenha sido discreto. Já para as moléculas CD14, CD11c e HLA-DR, para as quais se observa um padrão recorrente com relação à freqüência 
de células positivas, variaram bastante em relação à $\mathrm{MFI}$, com exceção de CD14 em iDCs e mDCs.

Essas variação entre os fenótipos das células dendríticas humanas diferenciadas in vitro, mais evidente em algumas moléculas do que em outras, pode, além das considerações já sugeridas, ser explicada pela grande heterogeneidade das células dendríticas, já que nenhum modelo completo de vias de desenvolvimento foi estabelecido (KAH-WAl et al., 2006). Soma-se a isso a variação natural existente entre os doadores, tanto genética quanto ambiental. $\mathrm{Na}$ verdade, nosso laboratório já mostrou que, ao menos em modelo murino, até mesmo o nível de estresse do animal é capaz de alterar fenotipicamente as células dendríticas e a capacidade de diferenciação de precursores neste tipo celular (TOMIYOSHI et al., 2009).

Ainda, o meio de cultura, como mencionado, parece causar intensa variação, particularmente nas moléculas co-estimuladoras CD80 e CD86. As diferenciações em DCs realizadas em meio RPMI suplementado com $10 \%$ de soro fetal bovino (SFB) (R-10) - não mostradas - indicaram aumento importante na porcentagem de iDCs positivas para CD80 e CD86. Apesar das vantagens conferidas na utilização de meio contendo SFB, como por exemplo aumento no rendimento final da cultura e menor suscetibilidade à morte devido manipulação das células, necessária para a transfecção com siRNAs, tornou-se inviável a utilização dessas DCs nas tentativas de silenciamento, uma vez que CD80, em particular, já está presente em média em $60 \%$ das iDCs cultivadas em R-10.

Sabe-se que a eficiência do silenciamento mediado por siRNAs depende fortemente da estabilidade da proteína na superfície. Embora possa ser possível atingir o silenciamento no que se refere ao mRNA, as células podem ainda conter uma grande quantidade de proteína na superfície devido grande estabilidade das mesmas, e o efeito de silenciamento não é percebido, ou é ineficiente (PRECHTEL et al., 2007). Isso é de grande relevância para as moléculas CD80 e CD86, as quais possuem grande estabilidade na membrana, como demonstrado por Prechtel et al. (2007), e em particular para a molécula CD86, uma vez que mostrou-se que a porcentagem de células positivas para este marcador é elevada desde o monócito. Ao utilizarem ciclohexamida para bloquer a síntese de novas proteínas em DCs maduras, a fim de avaliar a estabilidade de algumas moléculas de superfície dessas células, constataram que mesmo após 72 horas, não houve alteração na 
porcentagem de células positivas para CD80 e CD86 (PRECHTEL et al., 2007). Há ainda outras evidências indicando que CD80 possui alta estabilidade na membrana, podendo permanecer por até 5 dias (SAMSON; MANZOTTI; ZHENG, 2003; BATHIA et al., 2006). Além disso, a integridade do siRNA no interior das células também pode variar, podendo permanecer sem degradação por 3 - 5 dias (WU e BELASCO, 2008). Esses dados nos levram à preferência de utilização do meio AIM-V em detrimento do R-10 na tentativa de silenciamento das moléculas co-estimuladoras.

Independente da presença constitutiva de CD86 na membrana celular, observou-se aumento de expressão de CD86, assim como de CD80, após ativação das células (Figura 10). Julgou-se, pois, importante para o sucesso do silenciamento, identificar o momento em que ocorria o pico de expressão do mRNA para essas moléculas. Assim, avaliou-se a cinética de expressão de mRNA das mesmas por PCR em tempo real (Figura 11). Os resultados de dois experimentos independentes foram inconclusivos para CD86, mas não para CD80. Aparentemente, já mediante adição das citocinas GM-CSF e IL-4 no dia zero da cultura, que causam a diferenciação do monócito em célula dendrítica, há estímulo de transcrição do mRNA para CD80. Isso é consistente com a presença de células $\mathrm{CD}^{+} 0^{+}$observada em células no quinto dia da cultura. No experimento em que houve indução de expressão de CD86 (experimento 1), esta apenas ocorreu após ativação das células com TNF- $\alpha$. Curiosamente, no experimento em que, por algum motivo, a produção de mRNA para CD86 foi basal, ou seja, semelhante à do monócito (experimento 2), a expressão dessa molécula na superfície não se manteve elevada, como normalmente se observa no fenótipo de iDCs e mDCs, e como se observou no experimento 1 de cinética.

Embora seja comumente aceito que a DC é uma célula de difícil transfecção (PEDERSEN; FANG; PEDERSEN, 2009), o protocolo de transfecção reversa padronizado gerou, tanto com o agente de transfecção siPORT quanto com o iMAX, uma porcentagem alta de células transfectadas $(64,7 \% \pm 5,2 \%$ e $69,7 \% \pm 14,5 \%$, respectivamente). Apesar da alta transfecção, com ambos os agentes observou-se a formação de duas populações de células granulosas mas com tamanhos diferentes, as quais foram chamadas neste de DC 1 e DC 2, sendo DC 1 a população com tamanho e granulosidade esperada de DCs. Na transfecção com iMAX foi possível comprovar por marcação com anexina-PI que a população DC 2, formada após 48 horas da transfecção, era composta quase que em sua totalidade por células 
mortas. É possível sugerir, portanto, que a população DC 2, formada após 24 horas da transfecção com o agente siPORT, também é composta por células mortas. $\mathrm{Na}$ transfecção com ambos os agentes observou-se que a população de células mortas aparecia independentemente do tratamento. Assim, esses dados sugerem que nem o agente de transfecção, nem os siRNAs usados causam aumento de citotoxicidade celular, e as diferenças observadas em relação ao tempo de aparecimento dessas populações com os diferentes agentes talvez se devam a diferentes metodologias para recuperação das células das placas de cultura. É, portanto, possível dizer que a viabilidade conferida pelos diferentes agentes de transfecção é similar, e em torno de $30 \%$, independente do tratamento.

Porém, nas tentativas de silenciamento de CD80 e CD86 em DCs diferenciadas em R-10, em que se avaliou por marcação com anexina-PI a viabilidade das células transfectadas por iMAX 48 horas após a transfecção (experimento pareado ao de marcação com anexina-PI descrito), não observou-se a formação da população DC 2, e a população DC 1 apresentava apenas cerca de $7,5 \%$ de células mortas independente do tratamento (dados não mostrados). Esses dados sugerem fortemente que a população de células mortas observada na transfecção de DCs originadas em culturas realizadas em meio AIM-V, decorre da manipulação das mesmas. Por algum motivo, a presença de SFB confere às DCs maior resistência à morte em decorrência da simples manipulação.

Com base na observação de que a ativação por TNF- $\alpha$ no quinto dia da cultura induzia aumento de transcrição dos mRNAs para CD80 e CD86, como também observado na utilização de outros agentes de transfecção (PEDERSEN; FANG; PEDERSEN, 2009; ZHENG et al., 2010), estabeleceu-se realizar a transfecção no quarto dia da cultura, 24 horas antes da ativação. Porém, não levouse em consideração que tanto o agente de transfecção siPORT, quanto o iMAX causavam ativação das DCs, com aumento importante de freqüência de células $\mathrm{CD}^{\circ} 0^{+}$. Acreditou-se que, possivelmente, a ausência de silenciamento era conseqüência da transfecção com siRNAs concomitante à ativação pelo agente de transfecção, uma vez que a tentou-se o silenciamento com ambos os agentes de transfecção (siPORT e iMAX) e diferentes estímulos de ativação (TNF- $\alpha$, LPS e coquetel de ativação), sem que nenhum efeito de silenciamento tivesse sido observado. 
Levantou-se, pois, a hipótese de que a ativação das DCs nos experimentos de silenciamento, realizada em dois momentos da cultura (pelos agentes de transfecção no quarto dia, e 24 horas após a transfecção com os diferentes ativadores mencionados), causaria a produção de mRNAs em excesso, de maneira a saturar a maquinaria envolvida nas vias de silenciamento, efeito já descrito na literatura (YI et al., 2005; GRIMM et al., 2006). Optou-se, portanto, pela não ativação das DCs transfectadas no quinto dia, com a avaliação do silenciamento no sexto dia, portanto, 48 horas após a transfecção com iMAX. Com essa nova estratégia, conseguiu-se o silenciamento da molécula CD80 em dois experimentos independentes, indicando que, de fato, a ativação das DCs parece ter um efeito critico sobre a eficácia do silenciamento de CD80.

Além do silenciamento da molécula alvo CD80, observou-se diminuição da população $C D 86^{\text {hi }}$, composta principalmente por células $\mathrm{CD} 80^{+} \mathrm{CD} 86^{+}$, e aumento da

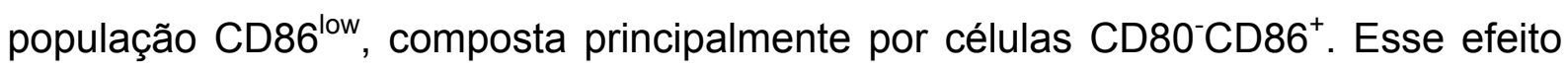
também foi observado na expressão relativa dessa molécula por PCR em tempo real. Avaliou-se a possibilidade de ligação dos siRNAs específicos para CD80 também no mRNA de CD86, por BLAST das seqüências com os transcritos do genoma humano (NCBI: http://blast.ncbi.nlm.nih.gov/). Porém, a análise descartou essa possibilidade. É pois, provável, que o silenciamento inespecífico observado seja resultado de um efeito off-target, em que, não raramente, observa-se silenciamento não intencional de um ou mais transcritos (FEDEROV et al., 2006). Demontrou-se que mesmo o pareamento de apenas 11 nucleotídeos é capaz de silenciar mRNAs não-alvos (JACKSON et al., 2003).

Realizou-se BLAST das seqüências de siRNAs específicos para CD80 em busca de qualquer homologia com o mRNA de CD86, em busca de um padrão correlacionando o silenciamento observado conferido pelas diferentes seqüências e a capacidade de pareamento com o mRNA de CD86. Não identificou-se padrão específico, e a complementariedade máxima foi de 8 nucleotídeos sem gap. É possível que além da complementariedade, a constituição das seqüências tenha influência no efeito a ser produzido (OLEJNICZAK; GALKA; KRZYZOSIAK, 2010), seja ele silenciamento da seqüência desejada ou não-desejada, seja ele indução de expressão de mRNA específico, como foi conferido pelo siRNA CD80-1. De fato, dsRNAs sintéticos administrados de maneira exógena podem efetivamente ativar um gene de maneira seqüência-específica, ao invés de silenciá-lo. Embora o 
mecanismo pelo qual isso ocorra ainda é incerto, a identificação desse fenômeno também pode vir a ter aplicações terapêuticas (PUSHPARAJ et al., 2007).

Já na análise do silenciamento de CD80 sobre a expressão de outras moléculas da célula dendrítica, como CD83 e HLA-DR, observou-se diminuição consistente do mRNA dessas moléculas na transfecção com todos os siRNAs utilizados, inclusive com o siRNA Scr. Essas observações sugerem se tratar de um processo inespecífico de bloqueio da transcrição, como mecanismo de defesa celular contra dsRNAs ou ssRNAs de origem viral por um ou mais dos mecanismos já mencionados (OLEJNICZAK; GALKA; KRZYZOSIAK, 2010), como ativação da PKR (IORDANOV et al., 2001) ou OAS (LI et al., 2004). A fim de confirmar essa possibilidade, ou melhor identificar o mecanismo específico que estaria agindo nesses casos, seria necessária a realização de outros experimentos.

Com relação à tentativa de silenciamento de CD86 em monócitos, houve apenas ligeira diminuição de células $\mathrm{CD}^{+} 6^{+}$, embora tenha-se observado o mesmo efeito de diminuição da população $C D 86^{\text {hi }}$ com conseqüente aumento da populção CD86 low, e diminuição da população $\mathrm{CD}^{\mathrm{l}} \mathrm{O}^{+}$. A estratégia realizada diferiu não apenas pela célula transfectada, neste caso os monócitos, mas também na estratégia de ativação, já que após 24 horas da transfecção, estes foram ativados com coquetel de ativação. Esta estratégia foi adotada a partir das observações de que CD86, como já é uma molécula constitutivamente expressa desde o monócito e, por dados de fenotipagem de Mo, iDCs e mDCs, há queda significativa de células $\mathrm{CD}^{+} 6^{+}$entre Mo e iDCs, ao longo da diferenciação as moléculas já presentes na superfície são recicladas, e a presença de siRNAs específicos poderia reduzir significativamente a porcentagem de $\mathrm{mDCs} \mathrm{CD}^{+} 6^{+}$ao final da cultura. A ativação realizada visou, sem muito sucesso, avaliar o melhor siRNA para CD86, para então prosseguir com os experimentos planejados. Porém, o siRNA CD80-1 foi perdido, possibilitando a comparação apenas entre os dois restantes. Embora o silenciamento tenha sido mínimo, é possível afirmar, com base nas observações realizadas, que o siRNA CD86-2 é mais eficiente que o CD86-3.

Além disso, a transfecção do monócito mostrou-se, aliada a uma segunda transfecção ao quinto dia, eficiente estratégia de silenciamento. Breton et al. (2009), após tentativas sem sucesso de silenciamento da molécula PD-L1 de células dendríticas com um pool de siRNAs contendo 4 duplexes, passaram a realizar dupla transfecção das células com um duplex de siRNA apenas, tanto no dia zero da 
cultura, como no quinto dia, o que aumentou significativamente a eficiência de silenciamento. Dado que PD-L1, regulador negativo de ativação, é uma molécula constitutivamente expressa desde o monócito, e sua expressão também é aumentada após ativação, assim como CD86, esta pode ser uma estratégia interessante para obtenção do silenciamento.

Com relação aos efeitos observados em decorrência do silenciamento de CD86, novamente, é possível que o fenômeno de diminuição de CD80 se deva ao já explicado efeito off-target. O BLAST do mRNA de CD80 com as seqüências de siRNAs de CD86 também não indicou um padrão. Não se avaliou o efeito do silenciamento de CD86 sobre CD80 por PCR em tempo real, não tendo sido possível realizar a avaliação da expressão dos mRNAs. Vale ainda ressaltar que, Arvey et al. (2010) descreveram, por meio de modelos matemáticos, a partir da observação do efeito produzido no mRNA pelo tratamento de células de linhagem com 178 miRNAs e siRNAs, que a abundância de mRNAs alvo pode significativamente reduzir a eficácia do silenciamento, o que concorda com a idéia de que a saturação da maquinaria envolvida nessa via é um fenômeno crítico para a obtenção do silenciamento (YI et al., 2005; GRIMM et al., 2006).

A análise do conjunto de resultados obtidos sugere, de maneira geral, que apesar da eficiente transfecção e da identificação de siRNAs específicos para CD80 e CD86, um efeito de modulação da expressão da outra molécula. Embora seja plausível que essa modulação seja desencadeada por efeito off-target, não se pode descartar a possibilidade de que essa modulação seja resultado da fisiologia do funcionamento dessas moléculas. De qualquer modo, o fenômeno, em si, é bastante intrigante. Se, por um lado, fazem considerar que os efeitos off-target podem levar a falsas interpretações como resultado do silenciamento de genes que não estão sendo observados (CLARK; POBER; KLUGER, 2008), por outro lado chamam a atenção para uma possibilidade de co-regulação da expressão destas duas moléculas. Sendo esta co-regulação um fenômeno real, seria necessário rever todos os dados onde se analisou o papel de uma delas pelo bloqueio da outra (por qualquer metodologia) e seria, talvez, possível entrever explicações para as observações aparentemente conflitantes quanto ao papel de cada uma delas na modulação dos padrões da resposta imune. 
6 CONCLUSÕES 
- Foi possível obter a transfeção eficiente de células dendríticas imaturas com siRNA-controle, pelo uso do agente de transfeção siPORT e iMAX, com resultados semelhantes.

- O silenciamento da expressão do CD80 em DCs imaturas dependeu do siRNA utilizado, sendo conseguidas eficiências que variaram entre $14 \%$ e $55 \%$, tanto quando se avaliou a expressão da proteína na superfície das células, quanto quando se mediu a quantidade de mRNA específico;

- O silenciamento da expressão de CD86 não foi bem sucedido, tendo-se apenas conseguido a modulação do nível de expressão desta molécula em monócitos ativados por citocinas - fenômeno também dependente do siRNA utilizado;

- O tratamento com siRNA para uma das duas moléculas, CD80 ou CD86 (e não com o siRNA controle), provoca alterações no nível de expressão da outra, superiores às observadas para outras moléculas analisadas. 
REFERÊNCIAS 


\section{REFERÊNCIAS*}

ARVEY, A.; LARSSON, E.; SANDER, C.; LESLIE, C. S.; MARKS, D. S. Target mRNA abundance dilutes microRNA and siRNA activity. Mol. Syst. Biol., v. 20, p. 363, 2010.

BALEEIRO, R. B.; ANSELMO, L. B.; SOARES, F. A.; PINTO, C.A.; RAMOS, O.; GROSS, J. L.; HADDAD, F.; YOUNES, R.N.; TOMIYOSHI, M. Y.; BERGAMISANTOS, P. C.; BARBUTO, J. A. High frequency of immature dendritic cells and altered in situ production of interleukin-4 and tumor necrosis factor-alpha in lung cancer. Cancer Immunol. Immunother., v. 57, p. 1335-1345, 2008.

BANCHEREAU, J.; STEINMAN, R. M. Dendritic cells and the controlo of immunity. Nature, v. 392, p. 245-252, 1998.

BARBUTO, J. A.; ENSINA, L. F.; NEVES, A. R.; BERGAMI-SANTOS, P.; LEITE, K. R.; MARQUES, R.; COSTA, F.; MARTINS, S. C.; CAMARA-LOPES, L. H.; BUZAID, A. C. Dendritic cell-tumor cell hybrid vaccination for metastatic cancer. Cancer Immunol. Immunother., v. 53, p. 1111-1118, 2004.

BATHIA, S.; EDININ, M.; ALMO, S. C.; NATHENSON, S. G. B7-1 and B7-2: Similar costimulatory ligands with different biochemical, oligomeric and signaling properties. Immunol. Lett., v. 104, p. 70-75, 2006.

BOYLAN, M. T.; CROCKARD, A. D.; MCDONNELL, G. V.; ARMSTRONG, M. A.; HAWKINS, S. A. CD80 (B7-1) and CD86 (B7-2) expression in multiple sclerosis patients: clinical subtype specific variation in peripheral monocytes and B cells and lack of modulation by high dose methylprednisolone. J. Neurol. Sci., v. 167, p. 7989, 1999.

BRETON, G.; YASSINE-DIAB, B.; COHN, L.; BOULASSEL, M. R.; ROUTY, J. P.; SÉKALY, R. P.; STEINMAN, R. M. siRNA Knockdown of PD-L1 and PD-L2 in monocyte-derived dendritic cells only modestly improves proliferative responses to Gag by CD8+ T cells from HIV-1-infected individuals. J. Clin. Immunol., v. 29, p. 637-645, 2009.

CAMPBELL, T. N.; CHOY, F. Y. RNA interference: past, present and future. Curr. Issues Mol. Biol., v. 7, p. 1-6, 2005. 
CARTHEW, R. W.; SONTHEIMER, E. J. Origins and mechanisms of miRNAs and siRNAs. Cell, v. 136, p. 642-655, 2009.

CHAUX, P.; MOUTET, M.; FAIVRE, J.; MARTIN, F.; MARTIN, M. Inflammatory cells infiltrating human colorectal carcinomas express HLA class II but not B7-1 and B7-2 costimulatory molecules of the T-cell activation. Lab. Invest., v. 74, p. 975-983, 1996.

CHU, C. Y.; RANA, T. M. Small RNAs: regulators and guardians of the genome. J. Cell Physiol., v. 213, p. 412-419, 2007.

CLARK; P. R.; POBER; J. S.; KLUGER, M. S. Knockdown of TNFR1 by the sense strand of an ICAM-1 siRNA: dissection of an off-target effect. Nucleic Acids Res., v. 36, p. 1081-1097, 2008.

CROSS, A. H.; GIRARD, T. J.; GIACOLETTO, K. S.; EVANS, R. J.; KEELING, R. M.; LIN, R. F.; TROTTER, J. L.; KARR, R. W. Long-term inhibition of murine experimental autoimmune encephalomyelitis using CTLA-4-Fc supports a key role for CD28 costimulation. J. Clin. Invest., v. 95, p. 2783-2789, 1995.

DELLA BELLA, S.; GENNARO, M.; VACCARI, M.; FERRARIS, C.; NICOLA, S.; RIVA, A.; CLERICI, M.; GRECO, M.; VILLA, M. L. Altered maturation of peripheral blood dendritic cells in patients with breast cancer. Br. J. Cancer, v. 89, p. 14631472, 2003.

DELLA BELLA, S.; NICOLA, S.; BRAMBILLA, L.; RIVA, A.; FERRUCCI, S.; PRESICCE, P.; BONESCHI, V.; BERTI, E.; VILLA, M. L. Quantitative and functional defects of dendritic cells in classic Kaposi's sarcoma. Clin. Immunol., v. 119, p. 317329, 2006.

FIELDS, P. E.; FINCH, R. J.; GRAY, G. S.; ZOLLNER, R.; THOMAS, J. L.; STURMHOEFEL, K.; LEE, K.; WOLF, S.; GAJEWSKI, T. F.; FITCH, F. W. B7.1 is a quantitatively stronger costimulus than B7.2 in the activation of naive CD8+ TCRtransgenic T cells. J. Immunol., v. 161, p. 5268-5275, 1998.

FINCK, B. K.; LINSLEY, P. S.; WOFSY, D. Treatment of murine lupus with CTLA4Ig. Science, v. 265, p. 1225-1227, 1994. 
FREEMAN, G. J.; BOUSSIOTIS, V. A.; ANUMANTHAN, A.; BERNSTEIN, G. M.; KE, X. Y.; RENNERT, P. D.; GRAY, G. S.; GRIBBEN, J. G.; NADLER, L. M. B7-1 and B7-2 do not deliver identical costimulatory signals, since B7-2 but not B7-1 preferentially costimulates the initial production of IL-4. Immunity, v. 2, p. 523-532, 1995.

GABRILOVICH, D. I.; CORAK, J.; CIERNIK, I. F.; KAVANAUGH, D.; CARBONE, D. $P$. Decreased antigen presentation by dendritic cells in patients with breast cancer. Clin. Cancer Res., v. 3, p. 483-490, 1997.

GAJEWSKI, T. F.; FALLARINO, F.; UYTTENHOVE, C.; BOON, T. Tumor rejection requires a CTLA4 ligand provided by the host or expressed on the tumor: superiority of B7-1 over B7-2 for active tumor immunization. J. Immunol., v. 156, p. 2909-2917, 1996.

GAJEWSKI, T. F. B7-1 but not B7-2 efficiently costimulates CD8+ T lymphocytes in the P815 tumor system in vitro. J. Immunol., v. 156, p. 465-472, 1996.

GREEN, J. M.; NOEL, P. J.; SPERLING, A. I.; WALUNAS, T. L.; GRAY, G. S.; BLUESTONE, J. A.; THOMPSON, C. B. Absence of B7-dependent responses in CD28-deficient mice. Immunity, v. 1, p. 501-508, 1994.

GREENWALD, R. J.; FREEMAN, G. J.; SHARPE, A. H. The B7 family revisited. Annu. Rev. Immunol., v. 23, p. 515-548, 2005.

GRIMM, D.; STREETZ, K. L.; JOPLING, C. L.; STORM, T. A.; PANDEY, K.; DAVIS, C. R.; MARION, P.; SALAZAR, F.; KAY, M. A. Fatality in mice due to oversaturation of cellular microRNA/short hairpin RNA pathways. Nature, v. 441, p. 537-541, 2006.

GU, X.; XIANG, J.; YAO, Y.; CHEN, Z. Effects of RNA interference on CD80 and CD86 expression in bone marrow-derived murine dendritic cells. Scand. J. Immonol., v. 64, p. 588, 2005.

GUINAN, E. C.; GRIBBEN, J. G.; BOUSSIOTIS, V. A.; FREEMAN, G. J.; NADLER, $\mathrm{L}$. M. Pivotal role of the $\mathrm{B} 7: \mathrm{CD} 28$ pathway in transplantation tolerance and tumor immunity. Blood, v. 84, p. 3261-3282, 1994.

HARDING, F. A.; MCARTHUR, J. G.; GROSS, J. A.; RAULET, D. H.; ALLISON, J. P. CD28-mediated signalling co-stimulates murine $T$ cells and prevents induction of anergy in T-cell clones. Nature, v. 356, p. 607-609, 1992. 
HARTGERS, F. C.; FIGDOR, C. G.; ADEMA, G. J. Towards a molecular understanding of dendritic cell immunobiology. Immunol. Today, v. 21, p. 542-545, 2000.

HASEBE, H.; NAGAYAMA, H.; SATO, K.; ENOMOTO, M.; TAKEDA, Y.; TAKAHASHI, T. A.; HASUMI, K.; ERIGUCHI, M. Dysfunctional regulation of the development of monocyte-derived dendritic cells in cancer patients, Biomed. Pharmacother., v. 54, p. 291-298, 2000.

HATHCOCK, K. S.; LASZLO, G.; PUCILLO, C.; LINSLEY, P.; HODES, R. J. Comparative analysis of $\mathrm{B} 7-1$ and $\mathrm{B} 7-2$ costimulatory ligands: expression and function. J. Exp. Med., v. 180, p. 631-640, 1994.

ISHIDA, T.; OYAMA, T.; CARBONE, D. P.; GABRILOVICH, D. I. Defective function of Langerhans cells in tumor-bearing animals is the result of defective maturation from hemopoietic progenitors. J. Immunol., v. 161, p. 4842-4851, 1998.

IORDANOV, M. S.; WONG, J.; BELL, J. C.; MAGUN, B.E. Activation of NF-kappaB by double-stranded RNA (dsRNA) in the absence of protein kinase $R$ and RNAse $L$ demonstrates the existence of two separate dsRNA-triggered antiviral programs. Mol. Cell Biol., v. 21, p. 61-72, 2001.

JACKSON, A. L.; BARTZ, S. R.; SHELTER, J.; KOBAYASHI, S. V.; BURSHARD, J.; MAO, M.; Li, B.; CAVET, G.; LINSLY, P. S. Expression profiling reveals off-target gene regulation by RNAi. Nat. Biotechnol., v. 21, p. 635-637, 2003.

KAH-WAI, L.; JACEK, T.; JACEK, R. Dendritic cells heterogeneity and its role in cancer immunity. J. Cancer Res. Ther., v. 2, p. 35-40, 2006.

KHOURY, S. J.; AKALIN, E.; CHANDRAKER, A.; TURKA, L. A.; LINSLEY, P. S.; SAYEGH, M. H.; HANCOCK, W. W. CD28-B7 costimulatory blockade by CTLA4Ig prevents actively induced experimental autoimmune encephalomyelitis and inhibits Th1 but spares Th2 cytokines in the central nervous system. J. Immunol., v. 155, p. 4521-4524, 1995.

KUCHROO, V. K.; DAS, M. P.; BROWN, J. A.; RANGER, A. M.; ZAMVIL, S. S.; SOBEL, R. A.; WEINER, H. L.; NABAVI, N.; GLIMCHER, L. H. B7-1 and B7-2 costimulatory molecules activate differentially the Th1/Th2 developmental pathways: application to autoimmune disease therapy. Cell, v. 80, p. 707-718, 1995. 
LANG, T. J.; NGUYEN, P.; PEACH, R.; GAUSE, W. C.; VIA, C. S. In vivo CD86 blockade inhibits CD4+ $T$ cell activation, whereas CD80 blockade potentiates CD8+ T cell activation and CTL effector function. J. Immunol., v. 168, p. 3786-3792, 2002.

LARSEN, C. P.; RITCHIE, S. C.; HENDRIX, R.; LINSLEY, P. S.; HATHCOCK, K. S.; HODES, R. J.; LOWRY, R. P.; PEARSON, T. C. Regulation of immunostimulatory function and costimulatory molecule (B7-1 and B7-2) expression on murine dendritic cells. J. Immunol., v. 152, p. 5208-5219, 1994.

LENSCHOW, D. J.; HO, S. C.; SATTAR, H.; RHEE, L.; GRAY, G.; NABAVI, N.; HEROLD, K. C.; BLUESTONE, J. A. Differential effects of anti-B7-1 and anti-B7-2 monoclonal antibody treatment on the development of diabetes in the nonobese diabetic mouse. J. Exp. Med., v. 181, p. 1145-1155, 1995a.

LENSCHOW, D. J.; WALUNAS, T. L.; BLUESTONE, J. A. CD28/B7 system of T cell costimulation. Annu. Rev. Immunol., v. 14, p. 233-258, 1996.

LENSCHOW, D. J.; ZENG, Y.; HATHCOCK, K. S.; ZUCKERMAN, L. A.; FREEMAN, G.; THISTLETHWAITE, J. R.; GRAY, G. S.; HODES, R. J.; BLUESTONE, J. A. Inhibition of transplant rejection following treatment with anti-B7-2 and anti-B7-1 antibodies. Transplantation, v. 60, p. 1171-1178, 1995b.

LI,G.; XIANG, Y.; SABAPATHY, K.; SILVERMAN, R. H. An apoptotic signaling pathway in the interferon antiviral response mediated by RNAse $\mathrm{L}$ and c-Jun $\mathrm{NH} 2-$ terminal kinase. J. Biol. Chem., v. 279, p. 1123-1131, 2004.

LIN, H.; BOLLING, S. F.; LINSLEY, P. S.; WEI, R. Q.; GORDON, D.; THOMPSON, C. B.; TURKA, L. A. Long-term acceptance of major histocompatibility complex mismatched cardiac allografts induced by CTLA4Ig plus donor-specific transfusion. J. Exp. Med., v. 178, p. 1801-1806, 1993.

LINSLEY, P. S.; GREENE, J. L.; BRADY, W.; BAJORATH, J.; LEDBETTER, J. A.; PEACH, R. Human B7-1 (CD80) and B7-2 (CD86) bind with similar avidities but distinct kinetics to CD28 and CTLA-4 receptors. Immunity, v. 1, p. 793-801, 1994.

LIVAK, K. J.; SCHMITTGEN, T. D. Analysis of relative gene expression data using real-time quantitative PCR and the $2^{-\Delta \Delta C t}$ method. Methods, v. 25, p. 402-408, 2001.

LUTZ, M. B.; SCHULER, G. Immature, semi-mature and fully mature dendritic cells: which signals induce tolerance or immunity? Trends Immunol., v. 23, p. 445-449, 2002. 
LYONS, A. B. Analysing cell division in vivo and in vitro using flow cytometric measurement of CFSE dye dilution. J. Immunol. Methods, v. 243, p. 147-154, 2000.

MANZOTTI, C. N.; LIU, M. K.; BURKE, F.; DUSSABLY, L.; ZHENG, Y.; SANSOM, D. $M$. Integration of CD28 and CTLA-4 function results in differential responses of $T$ cells to CD80 and CD86. Eur. J. Immunol., v. 36, p. 1413-1422, 2006.

MARQUES, J. T.; WILLIAMS, B. R. Activation of the mammalian immune system by siRNAs. Nat. Biotechnol., v. 23, p. 1399-1405, 2005.

MATTICK, J. S. RHA regulation: a new genetics? Nat. Rev. Genet., v. 5, p. 316-323, 2004.

MATTICK, J. S.; GAGEN, M. J. The evolution of controlled multitasked gene networks: the role of introns and other noncoding RNAs in the development of complex organisms. Mol. Biol. Evol., v. 18, p. 1611-1630, 2001.

MATULONIS, U.; DOSIOU, C.; FREEMAN, G.; LAMONT, C.; MAUCH, P.; NADLER, L. M.; GRIFFIN, J. D. B7-1 is superior to B7-2 costimulation in the induction and maintenance of $T$ cell-mediated antileukemia immunity. Further evidence that B7-1 and B7-2 are functionally distinct. J. Immunol., v. 156, p. 1126-1131, 1996.

NEVES, A. R. Estudo da diferenciação in vitro de células dendríticas derivadas de monócitos sangüíneos: análise dos efeitos de diferentes condições de cultura no fenótipo imunoestimulador das células. 2003. 95 f. Dissertação (Mestrado em Imunologia) - Instituto de Ciências Biomédicas, Universidade de São Paulo, São Paulo, 2003.

NEVES, A. R.; ENSINA, L. F.; ANSELMO, L. B.; LEITE, K. R.; BUZAID, A. C.; CÂMARA-LOPES, L. H.; BARBUTO, J. A. Dendritic cells derived from metastatic cancer patients vaccinated with allogeneic dendritic cell-autologous tumor cell hybrids express more CD86 and induce higher levels of interferon-gamma in mixed lymphocyte reactions. Cancer Immunol. Immunother., v. 54, p. 61-66, 2005.

ODOBASIC, D.; KITCHING, A. R.; SEMPLE, T. J.; TIMOSHANKO, J. R.; TIPPING, P. G.; HOLDSWORTH, S. R. Glomerular expression of CD80 and CD86 is required for leukocyte accumulation and injury in crescentic glomerulonephritis. J. Am. Soc. of Nephrol., v. 16, p. 2012-2022, 2005. 
OLEJNICZAK, M.; GALKA, P.; KRZYZOSIAK, W. J. Sequence-non-specific effects of RNA interference triggers and microRNA regulators. Nucleic Acids Res., v. 38, p. 116, 2009.

ORSINI, E.; GUARINI, A.; CHIARETTI, S.; MAURO, F. R.; FOA, R. The circulating dendritic cell compartment in patients with chronic lymphocytic leukemia is severely defective and unable to stimulate an effective T-cell response. Cancer Res., v. 63, p. 4497-4506, 2003.

PEDERSEN, C. D.; FANG, J. J.; PEDERSEN, A. E. A comparative study of transfection methods for RNA interference in bone marrow-derived murine dendritic cells. Scand. J. Immun., v. 70, p. 445-456, 2009.

PRECHTEL, A. T.; TURZA, N. M.; THEODORIDIS, A. A.; STEINKASSERER, A. CD83 Knockdown in monocyte-derived dendritic cells by small interfering RNA leads to diminished T cell stimulation. J. Immunol., v. 178, p. 5454-5464, 2007.

PREYNAT-SEAUVE, O.; SCHULER, P.; CONTASSOT, E.; BEERMANN, F.; HUARD, B.; FRENCH, L. E. Tumor-infiltrating dendritic cells are potent antigenpresenting cells able to activate $\mathrm{T}$ cells and mediate tumor rejection. J. Immunol., v. 176, p. 61-67, 2006.

PUSHPARAJ, P. N.; AARTHI, J. J., KUMAR, S. D.; MANIKANDAN, J. RNAi and RNAa - the yin and yang of RNAome. Bioinformation, v. 2, p. 235-237, 2008.

RACKE, M. K.; SCOTT, D. E.; QUIGLEY, L.; GRAY, G. S.; ABE, R.; JUNE, C. H.; PERRIN, P. J. Distinct roles for B7-1 (CD-80) and B7-2 (CD-86) in the initiation of experimental allergic encephalomyelitis. J. Clin. Invest., v. 96, p. 2195-2203, 1995.

RADVANYI, L. G.; SHI, Y.; VAZIRI, H.; SHARMA, A.; DHALA, R.; MILLS, G. B.; MILLER, R. G. CD28 costimulation inhibits TCR-induced apoptosis during a primary T cell response. J. Immunol., v. 156, p. 1788-1798, 1996.

RANGER, A. M.; DAS, M. P.; KUCHROO, V. K.; GLIMCHER, L. H. B7-2 (CD86) is essential for the development of IL-4-producing T cells. Int. Immunol., v. 8, p. 15491560, 1996.

SALEK-ARDAKANI, S.; ARENS, R.; FLYNN, R.; SETTE, A.; SCHOENBERGER, S. P.; CROFT, M. Preferential use of B7.2 and not B7.1 in priming of vaccinia virusspecific CD8 T cells. J. Immunol., v. 182, p. 2909-2918, 2009. 
SANSOM, D. M.; MANZOTTI, C. M.; ZHENG, Y. What's the difference between CD80 and CD86? Trends Immunol., v. 24, p. 313-318, 2003.

SAXON, A.; FELDHAUS, J.; ROBINS, R. A. Single step separation of human T and Bcells using AET treated srbc rosettes. J. Immunol. Methods, v. 12, p. 285-288, 1976.

SCHWEITZER, A. N.; BORRIELLO, F.; WONG, R. C.; ABBAS, A. K.; SHARPE, A. H. Role of costimulators in $T$ cell differentiation: studies using antigen-presenting cells lacking expression of CD80 or CD86. J. Immunol., v. 158, p. 2713-2722, 1997.

STACK, R. M.; LENSCHOW, D. J.; GRAY, G. S.; BLUESTONE, J. A.; FITCH, F. W. IL-4 treatment of small splenic B cells induces costimulatory molecules B7-1 and B72. J. Immunol., v. 152, p. 5723-5733, 1994.

STEINMAN, R .M. Dendritic cells: understanding immunogenicity. Eur. J. Immunol., v. 37, p. 53-60, 2007.

STEINMAN, R. M.; BANCHEREAU, J. Taking dendritic cells into medicine. Nature, v. 449, p. 429-416, 2007.

SZYMANSKY, M.; BARCISZEWSKI, J. Beonde the proteome: non-coding regulatory RNAs. Genome Biol., v. 3, p. 0005.1-0005.8, 2002.

THURNHER, M.; RADMAYR, C.; RAMONER, R.; EBNER, S.; BÖCK, G.; KLOCKER, H.; ROMANI, N.; BARTSCH, G. Human renal-cell carcinoma tissue contains dendritic cells. Int. J. Cancer, v. 68, p. 1-7, 1996.

TOMIYOSHI, M. Y.; SAKAI, M.; BALEEIRO, R. B.; STANKEVICIUS, D.; MASSOCO, C. O.; PALERMO-NETO, J.; BARBUTO, J. A. Cohabitation with a B16F10 melanoma-bearer cage mate influences behavior and dendritic cell phenotype in mice. Brain Behav. Immun., v. 23, p. 558-567, 2009.

VAN DIJK, A. M.; OTTEN, H. G.; VERCAUTEREN, S. M.; KESSLER, F. L.; DE BOER, M.; VERDONCK, L. F.; DE GAST, G. C. Human B7-1 is more efficient than B7-2 in providing co-stimulation for alloantigen-specific T cells. Eur. J. Immunol., v. 26, p. 2275-2278, 1996. 
VASILEVKO, V.; GHOCHIKYAN, A.; HOLTERMAN, M. J.; AGADJANYAN, M. G. CD80 (B7-1) and CD86 (B7-2) are functionally equivalent in the initiation and maintenance of CD4+ T-cell proliferation after activation with suboptimal doses of PHA. DNA Cell Biol., v. 21, p. 137-149, 2002.

YI, R.; DOEHLE, B. P.; QIN, Y.; MACARA, I. G.; CULLEN, B. R. Overexpression of exportin 5 enhances RNA interference mediated by short hairpin RNAs and microRNAs. RNA, v. 11 p. 220-226, 2005.

WALUNAS, T. L.; BLUESTONE, J. A. CTLA-4 regulates tolerance induction and T cell differentiation in vivo. J. Immunol., v. 160, p. 3855-3860, 1998.

WALUNAS, T. L.; LENSCHOW, D. J.; BAKKER, C. Y.; LINSLEY, P. S.; FREEMAN, G. J.; GREEN, J. M.; THOMPSON, C. B.; BLUESTONE, J. A. CTLA-4 can function as a negative regulator of T cell activation. Immunity, v. 1, p. 405-413, 1994.

WU, L.; BELASCO, J. G. Let me count the ways: mechanisms of gene regulation by miRNAs and siRNAs. Mol. Cell, v. 29, p. 1-7, 2008.

XIANG, J.; GU, X.; QIAN, S.; CHEN, Z. Graded function of CD80 and CD86 in initiation of T-cell immune response and cardiac allograft survival. Transpl. Int., v. 21, p. 163-168, 2008.

ZHENG, Y.; MANZOTTI, C. N.; LIU, M.; BURKE, F.; MEAD, K. I.; SANSOM, D. M. CD86 and CD80 differentially modulate the suppressive function of human regulatory T cells. The J. Immunol., v. 172, p. 2778-2784, 2004. 
ANEXO 


\section{ANEXO - Termo de Consentimento Livre e Esclarecido}

\section{TERMO DE CONSENTIMENTO LIVRE E ESCLARECIDO}

\section{ESTUDO: “AVALIAÇÃO DA FUNÇÃO DAS MOLÉCULAS CO-ESTIMULADORAS CD80 E CD86 EM CÉLULAS DENDRÍTICAS NA CAPACIDADE DE ATIVAÇÃO DE LINFÓCITOS T"}

Você está sendo convidado(a) a participar do projeto de pesquisa acima citado. O documento abaixo contém todas as informações necessárias sobre a pesquisa que estamos fazendo. Sua colaboração neste estudo será de muita importância para nós, mas se desistir a qualquer momento, isso não causará nenhum prejuízo a você. Quaisquer dúvidas entre em contato com os responsáveis pelo projeto:

Prof. Dr. José Alexandre Marzagão Barbuto e Isabella Katz Migliori (fone: 3091-7375).

$\mathrm{Eu}$, (inserir o nome, profissão, residente e domiciliado na)

., portador da Cédula de identidade, RG ............................ , e inscrito no CPF/MF nascido(a) em ___ l _ _ _ abaixo assinado(a), concordo de livre e espontânea vontade em participar como voluntário(a) do estudo "Avaliação da função das moléculas co-estimuladoras CD80 e CD86 em células dendríticas na capacidade de ativação de linfócitos T". Minha participação no estudo restringe-se à autorização de uso de material de descarte após minha doação de sangue para a pesquisa acima referida, de acordo com as normas dos bancos de sangue. Declaro que obtive todas as informações necessárias, bem como todos os eventuais esclarecimentos quanto às dúvidas por mim apresentadas.

Estou ciente que:

I) A doação deste material de descarte não vai alterar, de modo algum, os procedimentos referentes à doação de plaquetas a que me dispus;

II) A participação neste projeto não tem o objetivo de me submeter a qualquer tipo de tratamento;

III) A desistência não causará nenhum prejuízo à minha saúde ou bem estar físico, bem como não interferirá no atendimento ou tratamento médico em andamento ou futuros;

IV) Os resultados obtidos durante este projeto de pesquisa serão mantidos em sigilo, mas concordo que sejam divulgados em publicações científicas, desde que meus dados pessoais não sejam mencionados;

V) $\mathrm{O}$ estudo pretende compreender melhor a função das moléculas co-estimuladoras CD80 e CD86 na ativação de linfócitos T, para futuramente modular a expressão 
dessas moléculas na célula dendrítica, visando uma indução mais efetiva de resposta por células T na imunoterapia contra o câncer;

VI) Caso eu desejar, poderei pessoalmente tomar conhecimento dos resultados, ao final desta pesquisa.

( ) Desejo conhecer os resultados desta pesquisa.

( ) Não desejo conhecer os resultados desta pesquisa.

São Paulo, de de 2009.

( )Doador/ ( ) Responsável

Testemunha 1 :

Nome / RG / Telefone

Testemunha 2 :

Nome / RG / Telefone 